\title{
Guanidinophosphazenes: Design, Synthesis and Basicity in THF and in the Gas Phase
}

\section{Supporting Information}

Alexander A. Kolomeitsev, ${ }^{* 1}$ Ilmar A. Koppel, ${ }^{* 2}$ Toomas Rodima, ${ }^{2}$ Jan Barten, ${ }^{3}$ Enno Lork, ${ }^{1}$ G.-V.

Röschenthaler, ${ }^{1}$ Ivari Kaljurand, ${ }^{2}$ Agnes Kütt, ${ }^{2}$ Ivar Koppel, ${ }^{2}$ Vahur Mäemets, ${ }^{2}$ Ivo Leito ${ }^{2}{ }^{2}$

${ }^{1}$ Institute of Inorganic and Physical Chemistry, University of Bremen, Leobener Strasse, D-28334 Bremen, Germany;

${ }^{2}$ University of Tartu, Department of Chemistry, Jakobi 2 str, 51014 Tartu, Estonia

${ }^{3}$ Hansa Fine Chemicals GmbH, Leobener Straße, NW2 C, D-28359, Bremen, Germany

kolomeit@chemie.uni-bremen.de, Ilmar.koppel@ut.ee, ivo.leito@ut.ee

\section{Table of Contents}

Synthesis and Liberation Procedures

Page S2

Table S1. Ionic radii of the ions

Page S16

Details of the UV-Vis Spectrophotometric Measurement Method

Page S17

Crystal Structure Analyses

Page S22 
Table S2. Results of basicity calculations

Page S26

References (full citations)

Page S30

Optimized Geometries Obtained from the Computations

Page S31

\section{Synthesis and Liberation Procedures}

General. The Kirsanov or Staudinger reaction schemes were used for the synthesis of the guanidinophosphazene bases. The tris-(tetramethylguanidino)chlorophosphonium salt $(\operatorname{tmg})_{3} \mathrm{P}^{+} \mathrm{Cl} \cdot \mathrm{Cl}^{-}$ was readily prepared at $-30^{\circ} \mathrm{C}$ in chlorobenzene or methylene chloride solution from $\mathrm{TMG}$ and $\mathrm{PCl}_{5}$. The $t$ - $\mathrm{BuNPCl}_{3}$ and $t-\mathrm{BuNPCl}_{2} \mathrm{NEt}_{2}{ }^{1 \mathrm{~b}}$ and the $\mathrm{P}_{2}$ and $\mathrm{P}_{4}$ phosphonium salts for the synthesis of various phenylsubstituted $\mathrm{P}_{2}$ and $\mathrm{P}_{4}$ phosphazenes were prepared according to literature methods. ${ }^{1}$ In the case of the $\mathrm{P}_{4}$ compounds the used anilines served also as reaction media. The detailed descriptions of the synthesis and characterization data of compounds can be found below.

$t-\mathrm{BuNH}_{2} \cdot \mathrm{HCl}$ was prepared by adding $\mathrm{HCl}$ solution in diethyl ether to the amine solution in diethyl ether. $\mathbf{3 9 b ^ { 2 }}, \mathbf{2 8 c ^ { 3 }}$, 1,8-bis(tetramethylguanidino)naphthalene ${ }^{4}, \mathbf{3 0 b}^{5}$ as well phenyl ${ }^{6}$ and 2chlorophenyl azides ${ }^{7}$ were synthesized according to published procedures. Commercial TMG was used without additional purification. Melting points are uncorrected.

WARNING: Azides can decompose explosively and must be handled carefully!

Solvents. Solvents used for synthesis were dried by standard methods. ${ }^{8}$ THF and monoglyme were distilled from sodium/potassium alloy before used. Methylene chloride and chlorobenzene were distilled over diphosphorous pentoxide. Methylene chloride for extraction of guanidinophosphazenium salts was used as purchased. The Super Purity grade and "pure" THF redistilled from $\mathrm{LiAlH}_{4}$ were used for spectrophotometric measurements. 
$(\mathbf{t m g})_{3} \mathbf{P}=\mathbf{N H} \cdot \mathbf{H B P h}_{\mathbf{4}}\left(\mathbf{8 a} \cdot \mathbf{H B P h}_{4}\right)$ was prepared by adding to a solution of $\mathbf{8 a} \cdot \mathbf{H B F}$ in $\mathrm{MeOH}$ a calculated amount of $\mathrm{NaBPh}_{4}$ solution in $\mathrm{MeOH}$, mp $132.2-133.0{ }^{\circ} \mathrm{C}$. Anal. Calcd for $\mathrm{C}_{39} \mathrm{H}_{58} \mathrm{BN}_{10} \mathrm{P}$ : C, 66.09\%; H, 8.25\%; N, 19.76\%. Found: C, 66.40\%; H, 8.28\%; N, 19.72\%. HRMS of the protonated base: $\mathrm{m} / \mathrm{z}$ calcd. for $\mathrm{C}_{15} \mathrm{H}_{38} \mathrm{~N}_{10} \mathrm{P}$ 389.30070. Found $389.30028\left(\mathrm{M}^{+}\right) .{ }^{1} \mathrm{H}$ NMR $(200.13 \mathrm{MHz}$, THF) $\delta$ 2.76, $5.37(\mathrm{~m}, 2 \mathrm{H}), 6.70\left(\mathrm{t}, 4 \mathrm{H}, J_{H-H}=7.1\right), 6.85\left(\mathrm{t}, 8 \mathrm{H}, J_{H-H(a v)}=7.5\right), 7.27(\mathrm{~m}, 8 \mathrm{H}) .{ }^{13} \mathrm{C} \mathrm{NMR}(50.32$ $\mathrm{MHz}, \mathrm{THF}) \delta 40.33,121.72,125.6\left(\mathrm{~m}, J_{C-B}=2.8\right), 137.2\left(\mathrm{~m}, J_{C-B}=1.3\right), 161.5\left(\mathrm{~d}, J_{C-P}=2.4\right), 165.2(\mathrm{~m}$, $\left.J_{C-B}=49.4\right)$.

(tmg) $)_{3} \mathbf{P}=\mathbf{N}$-Et (8b). In $25 \mathrm{~mL}$ of dry dichloromethane 10.0 mmole $(2.08 \mathrm{~g})$ of $\mathrm{PCl}_{5}$ was suspended at $-30{ }^{\circ} \mathrm{C}$ and 60.0 mmole $(6.9 \mathrm{~g}, 7.5 \mathrm{~mL})$ of TMG was slowly added. The mixture was stirred and allowed to warm up to room temperature. After an hour the mixture was cooled to $-30 \mathrm{C}$ and cold solution (-15 C) of $11.1 \mathrm{mmol}(0.5 \mathrm{~g}, 0.74 \mathrm{~mL})$ of ethylamine in $1.8 \mathrm{~mL}(13 \mathrm{mmol})$ of triethylamine was added by means of syringe. The mixture was stirred until the ambient temperature was achieved and then set aside for two days. The crystal mass was filtered off and filtrate concentrated in vacuo to yield a nearly colorless glassy mass. It was dissolved in $15 \mathrm{~mL}$ of $70 \% \mathrm{EtNH}_{2}$ aq soln and $0.84 \mathrm{~g}$ of $\mathrm{NaBF}_{4}$ in $4 \mathrm{~mL}$ of water was added. The fine precipitate was filtered off, some water was added and $\mathrm{HBF}_{4}$ salt of product was extracted with dichloromethane. The layers were separated, organic layer was dried with $\mathrm{MgSO}_{4}$. The solvent was removed under reduced pressure (finally at $80{ }^{\circ} \mathrm{C} / 0.3$ Torr) to give bright viscous oil. By adding a small amount of ethyl acetate and crushing with glass stick a white crystalline mass was got. Recrystallisation was made from 1:7 mixture of $\mathrm{CHCl}_{3} / \mathrm{EtOAc}$. Yield $30 \%$ (1.5 g) of $\mathbf{8 b} \cdot \mathbf{H B F} \mathbf{4}$ (reaction conditions are not optimized), mp $102.8-104.1{ }^{\circ} \mathrm{C}$. Anal. Calc. for $\mathrm{C}_{17} \mathrm{H}_{42} \mathrm{BF}_{4} \mathrm{~N}_{10} \mathrm{P}: \mathrm{C}$, 40.48\%; H, 8.39\%; N, 27.77\%. Found: C, 40.63\%; H, 8.62\%; N, 28.09\%. ${ }^{1} \mathrm{H}$ NMR (200.13 MHz, THF) $\delta 1.09\left(\mathrm{dt}, 3 \mathrm{H}, J_{P-H}=0.9, J_{H-H}=7.2\right), 2.83\left(\mathrm{dq}, 2 \mathrm{H}, J_{H-H}=7.2, J_{P-H}=2.1\right), 2.89\left(\mathrm{~d}, 36 \mathrm{H}, J_{P-H}=0.6\right)$. ${ }^{13} \mathrm{C}$ NMR (50.32 MHz, THF) $\delta 17.5\left(\mathrm{~d}, J_{C-P}=7.7\right), 36.7,40.5,161.6\left(\mathrm{~d}, J_{C-P}=3.3\right)$.

The free base was liberated from its $\mathrm{HBF}_{4}$ salt by means of t-BuOK in DME according to the general procedure to give colorless viscous oil. ${ }^{1} \mathrm{H}$ NMR $(200.13 \mathrm{MHz}, \mathrm{THF}) \delta 0.97\left(\mathrm{dt}, 3 \mathrm{H}, J_{P-H}=1.6, J_{H-H}=\right.$ 
7.1), $2.80(\mathrm{~s}, 36 \mathrm{H}), 3.04\left(\mathrm{dq}, 2 \mathrm{H}, J_{P-H}=18.8, J_{H-H}=7.1\right) .{ }^{13} \mathrm{C} \mathrm{NMR}(50.32 \mathrm{MHz}, \mathrm{THF}) \delta 22.9\left(\mathrm{~d}, J_{C-P}=\right.$ $22.4), 40.4,41.5\left(\mathrm{~d}, J_{C-P}=5.5\right), 158.4\left(\mathrm{~d}, J_{C-P}=1.9\right)$.

$(\mathbf{t m g})_{3} \mathbf{P}=\mathbf{N}-t-B u(8 c)$. A solution of $24.2 \mathrm{~g}(116.1 \mathrm{mmol})$ of $t$-butyl-iminophosphorus trichloride in absolute chlorobenzene $(300 \mathrm{~mL})$ was cooled to $-20^{\circ} \mathrm{C}$. Via a dropping funnel $98.0 \mathrm{~g}(852.2 \mathrm{mmol}) \mathrm{of}$ tetramethylguanidine was added during $0.5 \mathrm{~h}$. The mixture was allowed to warm to $20^{\circ} \mathrm{C}$, and was stirred at this temperature for $1 \mathrm{~h}$ and then warmed to $80^{\circ} \mathrm{C}$ and kept at that temperature overnight. The tetramethylguanidine hydrochloride was collected by filtration and washed with chlorobenzene $(2 \times 50$ $\mathrm{mL})$. The solvent and an excess of tetramethylguanidine were pumped off in vacuo (10 ${ }^{-2}$ Torr) to afford a raw $\mathbf{8 c} \cdot \mathbf{H C l}$ as a colorless solid. The chloride salt was dissolved in water $(100 \mathrm{~mL})$, treated with 13.75 $\mathrm{g}(125 \mathrm{mmol})$ of $\mathrm{NaBF}_{4}$ and the tetrafluoroborate salt was extracted with methylene chloride $(3 \times 70$ $\mathrm{mL})$. The solvent was removed in vacuo furnishing $60.1 \mathrm{~g}(98.8 \%)$ of colorless crystals $\mathbf{8 c} \cdot \mathbf{H B F}$, $\mathrm{mp}$ 124- $125^{\circ} \mathrm{C} .{ }^{1} \mathrm{H}$ NMR $\left(200.13 \mathrm{MHz}, \mathrm{CDCl}_{3}\right) \delta 1.17(\mathrm{~s}, 9 \mathrm{H}), 2.37\left(\mathrm{~d}, 1 \mathrm{H}, J_{H-P}=7.3\right), 2.83(\mathrm{~s}, 36 \mathrm{H}) .{ }^{13} \mathrm{C}$ $\operatorname{NMR}\left(50.32 \mathrm{MHz}, \mathrm{CDCl}_{3}\right) \delta 31.8\left(\mathrm{~d}, J_{C-P}=4.2\right), 40.7,50.9,160.2 .{ }^{31} \mathrm{P} \mathrm{NMR}\left(81.00 \mathrm{MHz}, \mathrm{CDCl}_{3}\right) \delta-$ $11.7\left(\mathrm{~d}, J_{P-H}=7.3\right) .{ }^{19} \mathrm{~F}$ NMR $\left(188.31 \mathrm{MHz}, \mathrm{CDCl}_{3}\right) \delta-151.0\left(\mathrm{BF}_{4}\right)$. Anal. Calcd for $\mathrm{C}_{19} \mathrm{BF}_{4} \mathrm{H}_{46} \mathrm{~N}_{10} \mathrm{P}: \mathrm{C}$, 42.86\%; H, 8.71\%; N, 26.31\%. Found: C, 42.82\%; H, 8.76\%; N, 26.27\%.

The free base was prepared according to the general procedure: from $27.2 \mathrm{~g}(51.1 \mathrm{mmol}) \mathrm{of} 8 \mathrm{c} \cdot \mathrm{HBF}_{4}$ and $5.7 \mathrm{~g}(51.1 \mathrm{mmol}) t$-BuOK in monoglyme $(200 \mathrm{~mL}), 18.8 \mathrm{~g}(83 \%)$ of the base was collected as colorless crystals, mp $104-105{ }^{\circ} \mathrm{C}\left(\right.$ from hexane at $\left.-30{ }^{\circ} \mathrm{C}\right) .{ }^{1} \mathrm{H}$ NMR $\left(200.13 \mathrm{MHz}, \mathrm{C}_{6} \mathrm{D}_{6}\right) \delta 1.71(\mathrm{~s}$, 9H), $2.73(\mathrm{~s}, 36 \mathrm{H}) .{ }^{31} \mathrm{P}$ NMR $\left(81.00 \mathrm{MHz}, \mathrm{C}_{6} \mathrm{D}_{6}\right) \delta$-23.7 (s). ${ }^{13} \mathrm{C} \mathrm{NMR}\left(50.32 \mathrm{MHz}, \mathrm{C}_{6} \mathrm{D}_{6}\right) \delta 35.9(\mathrm{~d}$, $\left.J_{C-P}=12.3\right), 40.0\left(\mathrm{~d}, J_{C-P}=4.6\right), 40.4,156.5$ (d, $\left.J_{C-P}=3.0\right)$. HRMS (EI) calcd. for $\mathrm{C}_{19} \mathrm{H}_{45} \mathrm{~N}_{10} \mathrm{P} 444.35663$. Found: 444.35506.

$(\mathbf{t m g})_{3} \mathbf{P}=\mathbf{N}-\mathbf{P h}(\mathbf{8 d})$. Trichloromethyltrimethylsilane $(5.0 \mathrm{mmole}, 0.96 \mathrm{~g})$ was mixed with $5.0 \mathrm{mmole}$ $(0.58 \mathrm{~g})$ of TMG at room temperature and heated at $120-130{ }^{\circ} \mathrm{C}$ under argon flow and stirring for $3 \mathrm{~h}$. 
The evolved chloroform was distilled off (finally under light vacuum). The rest, tetramethylguanidinotrimethylsilane was dissolved in $2.5 \mathrm{~mL}$ of toluene, thrown into syringe and added slowly to a solution of 4.2 mmole $(0.58 \mathrm{~g}) \mathrm{PCl}_{3}$ in $3.0 \mathrm{~mL}$ of toluene. The mixture was stirred for $1 \mathrm{~h}$ and then heated to remove volatile compounds at 160 Torr. The rest, tan viscous oil was cooled to room temperature and $4.2 \mathrm{mmol}(0.5 \mathrm{~g})$ of phenyl azide ${ }^{6}$ was added. The temperature of mixture was going warm. After a hour $12.6 \mathrm{mmol}(1.46 \mathrm{~g})$ of TMG and $4.0 \mathrm{~mL}$ of toluene were added to reaction mixture, refluxed about half an hour and left then for a night. To the cool mixture $5.0 \mathrm{~mL}$ of THF was added, precipitate was filtered off and filtrate concentrated (finally at $80{ }^{\circ} \mathrm{C} / 4$ Torr). The rest, tan viscous mass was treated with 8.0 $\mathrm{mL}$ of THF. The bright precipitate $(0.5 \mathrm{~g})$ of product $\mathrm{HCl}$ salt was collected, dissolved in $1.5 \mathrm{~mL}$ of methanol and precipitated as $\mathrm{HBPh}_{4}$ salt by means of $\mathrm{NaBPh}_{4}$ solution in methanol. The $\mathrm{HBPh}_{4}$ salt was dissolved in 2:5 mixture of $\mathrm{MeOH} / \mathrm{MeCN}$, filtered and solvent removed. Yield 15\% (reaction conditions are not optimised) of $\mathbf{8 d} \cdot \mathbf{H B P h}_{4}, \mathrm{mp}$ 128.0-130.8 ${ }^{\circ} \mathrm{C}$. Anal. Calcd. For $\mathrm{C}_{45} \mathrm{H}_{62} \mathrm{BN}_{10} \mathrm{P}: \mathrm{C}$, 68.87\%; H, 7.96\%; N, 17.85\%. Found: C, 69.11\%; H,7.97\%; N, 17.88\%. ${ }^{1} \mathrm{H}$ NMR $(200.13 \mathrm{MHz}$, MeCN) $\delta 2.77\left(\mathrm{~d}, 36 \mathrm{H}, J_{P-H}=0.4\right), 5.89\left(\mathrm{~d}, 1 \mathrm{H}, J_{P-H}=8.0\right), 6.7-6.9(\mathrm{~m}, 7 \mathrm{H}), 6.99\left(\mathrm{t}, 8 \mathrm{H}, J_{H-H}=7.4\right), 7.27$ $(\mathrm{m}, 8 \mathrm{H}) .{ }^{13} \mathrm{C}$ NMR $(50.32 \mathrm{MHz}, \mathrm{MeCN}) \delta 40.5,116.8\left(\mathrm{~d}, J_{C-P}=6.8\right), 120.7,122.7,126.5\left(\mathrm{~m}, J_{B-C}=\right.$ $2.8), 129.8,136.8\left(\mathrm{~m}, J_{B-C}=1.6\right), 143.3\left(\mathrm{~d}, J_{C-P}=3.3\right), 161.9\left(\mathrm{~d}, J_{C-P}=4.5\right), 164.8\left(\mathrm{~m}, J_{B-C}=49.4\right)$.

Free base $\mathbf{8 d}$ was liberated from its $\mathrm{HBPh}_{4}$ salt by means of $\mathrm{MeOK}$ according to general procedure to give colorless crystals. ${ }^{1} \mathrm{H}$ NMR $(200.13 \mathrm{MHz}, \mathrm{THF}) \delta 2.76\left(\mathrm{~d}, 36 \mathrm{H}, J_{P-H}=0.3\right), 6.05\left(\mathrm{tt}, 1 \mathrm{H}, J_{H-H}=7.1\right.$, $\left.J_{H-H}=1.3\right), 6.41\left(\mathrm{ddd}, 2 \mathrm{H}, J_{H-H}=8.5, J_{H-H}=1.3, J_{P-H}=0.7\right), 6.68(\mathrm{~m}, 2 \mathrm{H}) .{ }^{13} \mathrm{C}$ NMR $(50.32 \mathrm{MHz}, \mathrm{THF})$ $\delta 40.2,112.0,121.5\left(\mathrm{~d}, J_{C-P}=22.2\right), 128.2\left(\mathrm{~d}, J_{C-P}=2.4\right), 156.2,159.9$.

$(\mathbf{d m a})_{2}(\mathbf{t m g}) \mathbf{P}=\mathbf{N}-\mathbf{P h}(\mathbf{9})$.To a solution of $10 \mathrm{mmol}(1.55 \mathrm{~g})$ of $\left(\mathrm{Me}_{2} \mathrm{~N}\right)_{2} \mathrm{PCl}^{3}$ in $15 \mathrm{~mL}$ of dry benzene a solution of $10 \mathrm{mmol}(1.20 \mathrm{~g})$ of phenyl azide ${ }^{6}$ in $10 \mathrm{~mL}$ of benzene was added, and the mixture was refluxed for $2 \mathrm{~h}$. To the warm solution $30 \mathrm{mmol}(3.5 \mathrm{~g})$ of TMG was added dropwise and the mixture refluxed again for $2 \mathrm{~h}$. The solvent was distilled off and remaining brown oil heated at $120{ }^{\circ} \mathrm{C}$ still $3 \mathrm{~h}$. 
To the cooled matter $12 \mathrm{~mL}$ of benzene was added and mixture was left for overnight. The TMG.HCl was filtered off ( $5 \mathrm{mmol}$ of salt was gathered), solvent removed (finally at $90{ }^{\circ} \mathrm{C} / 2$ Torr) and residue dissolved in $30 \mathrm{~mL}$ of $70 \%$ aq soln of $\mathrm{EtNH}_{2}$. The $\mathrm{NaBF}_{4}(8 \mathrm{mmol})$ solution in $20 \mathrm{~mL}$ of water was added to the solution and product as its $\mathrm{HBF}_{4}$ salt was extracted with $25 \mathrm{~mL}$ of $\mathrm{CH}_{2} \mathrm{Cl}_{2}$. The organic layer was separated, solvent evaporated, residue dissolved in $20 \mathrm{~mL}$ of $\mathrm{MeOH}$ and $\mathrm{NaBPh}_{4}(1.8 \mathrm{~g})$ solution in $20 \mathrm{~mL}$ of $\mathrm{MeOH}$ was added. The formed precipitate, light-brown crystal mass was recrystallized from $80 \mathrm{~mL}$ of $\mathrm{MeOH}$. The tan crystals were dissolved in hot 1:3 mixture of $\mathrm{MeCN} / \mathrm{MeOH}$, solution treated with activated charcoal and warm mixture was filtrated. Colorless crystals of $\mathbf{9} \cdot \mathrm{HBPh}_{4}$ were collected, yield $21 \%\left(1.4 \mathrm{~g}, \mathrm{mp}\right.$ 154.6-155.6 ${ }^{\circ} \mathrm{C}$, reaction conditions are not optimized). Anal. Calcd. for $\mathrm{C}_{39} \mathrm{H}_{50} \mathrm{BN}_{6} \mathrm{P}: \mathrm{C}, 72.66 \% ; \quad \mathrm{H}, 7.82 \% ; \mathrm{N}, 13.04 \%$. Found: C, 72.66\%; H, 7.89\%; N, 13.17\%. ${ }^{1} \mathrm{H}$ NMR (200.13 MHz, THF) $\delta 2.50\left(\mathrm{~d}, 12 \mathrm{H}, J_{P-H}=0.9\right), 2.62\left(\mathrm{~d}, 12 \mathrm{H}, J_{P-H}=10.5\right)$, 6.6-7.0 (m, 15H), 7.1-7.3 (m, 10H). ${ }^{13} \mathrm{C}$ NMR (50.32 MHz, THF) $\delta 37.2\left(\mathrm{~d}, J_{C-P}=4.5\right), 40.4,118.5(\mathrm{~d}$, $\left.J_{C-P}=7.0\right), 121.8,123.0,125.6\left(\mathrm{~m}, J_{C-B}=2.8\right), 130.3,137.1,140.5,161.8\left(\mathrm{~d}, J_{C-P}=11.2\right), 165.2\left(\mathrm{~m}, J_{C-}\right.$ $\left.{ }_{B}=49.4\right)$.

A sample of the free base was liberated from its $\mathrm{HBPh}_{4}$ salt by means of $\mathrm{MeOK}$ as described by the general procedure of liberation of bases. ${ }^{1} \mathrm{H}$ NMR $(200.13 \mathrm{MHz}, \mathrm{THF}) \delta 2.67\left(\mathrm{~d}, 12 \mathrm{H}, J_{P-H}=0.4\right), 2.72$ $\left(\mathrm{d}, 12 \mathrm{H}, J_{P-H}=9.6\right), 6.29\left(\mathrm{t}, 1 \mathrm{H}, J_{H-H}=7.1\right), 6.49\left(\mathrm{~d}, 2 \mathrm{H}, J_{H-H}=7.9\right), 6.81\left(\mathrm{t}, 2 \mathrm{H}, J_{H-H(a v)}=7.5\right) .{ }^{13} \mathrm{C} \mathrm{NMR}$ $(50.32 \mathrm{MHz}, \mathrm{THF}) \delta 37.9\left(\mathrm{~d}, J_{C-P}=2.6\right), 39.9,114.9,122.6\left(\mathrm{~d}, J_{C-P}=19.4\right), 128.6\left(\mathrm{~d}, J_{C-P}=1.9\right), 154.1$ $\left(\mathrm{d}, J_{C-P}=2.9\right)$

$(\mathbf{t m g})_{2}(\mathbf{d m a}) \mathbf{P}=\mathbf{N}-\mathbf{P h}(\mathbf{1 0})$. To a solution of $5.0 \mathrm{mmol}(0.73 \mathrm{~g}) \mathrm{Me}_{2} \mathrm{NPCl}_{2}{ }^{3}$ in $3 \mathrm{ml}$ of dry benzene a solution of $5.0 \mathrm{mmol}(0.6 \mathrm{~g})$ of phenyl azide ${ }^{6}$ in $3 \mathrm{ml}$ of benzene was added dropwise. The mixture was refluxed $2 \mathrm{~h}$, the benzene was distilled off and residue was heated at $120{ }^{\circ} \mathrm{C}$ for $1 \mathrm{~h}$. The reaction mixture was taken up in $5 \mathrm{ml}$ benzene and a solution of $15 \mathrm{mmole}(1.73 \mathrm{~g})$ of tetramethylguanidine in 3 $\mathrm{ml}$ of benzene was added, carefully cooling the mixture with ice water. The mixture was refluxed for 2 
$\mathrm{h}$ and left then to cool. Precipitated tetramethylguanidine $\mathrm{HCl}$ salt was filtered off and benzene removed (finally at $95{ }^{\circ} \mathrm{C} / 4$ Torr). Residue, brown glassy mass was taken up in $4 \mathrm{ml}$ of $\mathrm{MeOH}$, and a solution of $\mathrm{NaBPh}_{4}$ in $\mathrm{MeOH}$ was added to precipitate product as $\mathrm{HBPh}_{4}$ salt. Recrystallisation was made from 1:5 mixture of $\mathrm{MeOH} / \mathrm{MeCN}$. Yield $0.63 \mathrm{~g}\left(18 \%\right.$, not optimized) of colorless crystals of $\mathbf{1 0} \cdot \mathbf{H B P h}_{\mathbf{4}}, \mathrm{mp}$ 178-180 ${ }^{\circ} \mathrm{C}$. Anal. Calc. for $\mathrm{C}_{42} \mathrm{H}_{54} \mathrm{BN}_{8} \mathrm{P}: \mathrm{C}, 70.58 \%$; H, $7.62 \%$; N, $15.61 \%$. Found: $\mathrm{C}, 70.51 \%$; H7.91\%; N, 15,71\%. ${ }^{1} \mathrm{H}$ NMR $(200.13 \mathrm{MHz}, \mathrm{MeCN}) \delta 2.76\left(\mathrm{~d}, 6 \mathrm{H}, J_{P-H}=10.0\right), 2.81\left(\mathrm{~d}, 24 \mathrm{H}, J_{P-H}=\right.$ 0.6), $5.92\left(\mathrm{~d}, 1 \mathrm{H}, J_{P-H}=7.8\right), 6.8-7.1(\mathrm{~m}, 15 \mathrm{H}), 7.20\left(\mathrm{t}, 2 \mathrm{H}, J_{H-H}=7.9\right), 7.30(\mathrm{~m}, 8 \mathrm{H}) .{ }^{13} \mathrm{C} \mathrm{NMR}(50.32$ MHz, MeCN) $\delta 37.1\left(\mathrm{~d}, J_{C-P}=4.7\right), 40.7,118.0\left(\mathrm{~d}, J_{C-P}=7.1\right), 122.0,122.7,126.5\left(\mathrm{~m}, J_{B-C}=2.8\right), 130.1$, $136.8\left(\mathrm{~m}, J_{B-C}=1.6\right), 142.0\left(\mathrm{~d}, J_{C-P}=4.3\right), 162.5\left(\mathrm{~d}, J_{C-P}=6.0\right), 164.8\left(\mathrm{~m}, J_{B-C}=49.4\right)$.

Free base 10 was liberated from its $\mathrm{HBPh}_{4}$ salt by means of $\mathrm{MeOK}$ according to the general procedure to give colorless crystals. ${ }^{1} \mathrm{H}$ NMR $(200.13 \mathrm{MHz}, \mathrm{THF}) \delta 2.64\left(\mathrm{~d}, 6 \mathrm{H}, J_{P-H}=10.6\right), 2.74(\mathrm{~d}$, $\left.24 \mathrm{H}, J_{P-H}=0.4\right), 6.23\left(\mathrm{t}, 1 \mathrm{H}, J_{H-H}=7.1\right), 6.49\left(\mathrm{~d}, 2 \mathrm{H}, J_{H-H}=7.8\right), 6.78\left(\mathrm{t}, 2 \mathrm{H}, J_{H-H(a v)}=7.5\right) .{ }^{13} \mathrm{C} \mathrm{NMR}$ (50.32 MHz, THF) $\delta 38.1,40.0,114.2,122.6\left(\mathrm{~d}, J_{C-P}=19.3\right), 128.4\left(\mathrm{~d}, J_{C-P}=1.8\right), 155.1,160.3\left(\mathrm{~d}, J_{C-}\right.$ $\left.{ }_{P}=4.5\right)$.

$(\mathbf{t m g})_{2}\left(\mathbf{N E t}_{2}\right) \mathbf{P}=\mathbf{N}-\boldsymbol{t}-\mathrm{Bu}$ (11). To 6.69 mmole $(1.64 \mathrm{~g}) \mathrm{t}-\mathrm{BuNPCl}_{2}\left(\mathrm{NEt}_{2}\right)^{\mathbf{1 b}} 27.6$ mmole $(3.18 \mathrm{~g})$ of TMG was added at room temperature and the mixture heated at $120{ }^{\circ} \mathrm{C}$ for $17 \mathrm{~h}$. The cool mass was taken up in $5 \mathrm{~mL}$ of THF. 1,1,2-Trichloroethane $(0.5 \mathrm{~mL})$ was added to precipitate unreacted TMG. The precipitate was filtered off and filtrate concentrated (finally at $80{ }^{\circ} \mathrm{C} / 4$ Torr). The residue was dissolved in $6.0 \mathrm{~mL}$ of methanol and product converted to its salt by adding a solution of $2.0 \mathrm{~g} \mathrm{NaBPh}_{4}$ in methanol. Precipitate was filtered off, dried in vacuo and recrystallized from 1:17 mixture of $\mathrm{MeCN} / \mathrm{MeOH}$. The yield of $\mathbf{1 1} \cdot \mathbf{H B P h}_{\mathbf{4}}$ was $54 \%$ (2.6 g, not optimized), mp 150-151 ${ }^{\circ} \mathrm{C}$. Anal. Calc. for $\mathrm{C}_{42} \mathrm{H}_{64} \mathrm{BN}_{8} \mathrm{P}: \mathrm{C}, 69.79 \%$;, $8.92 \%$;, $15.50 \%$. Found: C, $69.96 \%, \mathrm{H}, 9.11 \% ; \mathrm{N}, 15.70 \%$. MS (ESI): $\mathrm{m} / \mathrm{z} 403\left(\mathrm{M}^{+}\right)$. 
${ }^{1} \mathrm{H}$ NMR (200.13 MHz, THF) $\delta 1.06\left(\mathrm{t}, 6 \mathrm{H}, J_{H-H}=7.1\right), 1.18\left(\mathrm{~d}, 9 \mathrm{H}, J_{P-H}=0.8\right), 2.72(\mathrm{~s}, 24 \mathrm{H}), 3.24$ $\left(\mathrm{dq}, 4 \mathrm{H}, J_{P-H}=10.9, J_{H-H}=7.1\right), 5.37\left(\mathrm{~d}, 1 \mathrm{H}, J_{P-H}=5.7\right), 6.70\left(\mathrm{t}, 4 \mathrm{H}, J_{H-H}=7.1\right), 6.85\left(\mathrm{t}, 8 \mathrm{H}, J_{H-H(a v)}=\right.$ 7.5), $7.27(\mathrm{~m}, 8 \mathrm{H}) .{ }^{13} \mathrm{C}$ NMR (50.32 MHz, THF) $\delta 14.1\left(\mathrm{~d}, J_{C-P}=2.8\right), 31.6\left(\mathrm{~d}, J_{C-P}=4.2\right), 40.5\left(\mathrm{~d}, J_{C-P}=\right.$ $3.3), 40.6,121.7,125.6\left(\mathrm{~m}, J_{B-C}=2.9\right), 137.2\left(\mathrm{~m}, J_{B-C}=1.4\right), 160.9,\left(\mathrm{~d}, J_{C-P}=6.5\right), 165.2\left(\mathrm{~m}, J_{B-C}=\right.$ 49.6).

The free base $\mathbf{1 1}$ was liberated from its $\mathrm{HBPh}_{4}$ salt by means of t-BuOK in DME. After removing of solvent a colorless oil was obtained.

${ }^{1} \mathrm{H}$ NMR (200.13 MHz, THF) $\delta 1.01\left(\mathrm{t}, 6 \mathrm{H}, J_{H-H}=7.1\right), 1.12\left(\mathrm{~d}, 9 \mathrm{H}, J_{P-H}=1.1\right), 2.82(\mathrm{~s}, 24 \mathrm{H}), 3.17$ $\left(\mathrm{dq}, 4 \mathrm{H}, J_{P-H}=9.4, J_{H-H}=7.7\right) .{ }^{13} \mathrm{C} \mathrm{NMR}(50.32 \mathrm{MHz}, \mathrm{THF}) \delta 15.0\left(\mathrm{~d}, J_{C-P}=5.0\right), 35.4\left(\mathrm{~d}, J_{C-P}=11.3\right)$, $40.5,40.8\left(\mathrm{~d}, J_{C-P}=2.3\right), 50.9\left(\mathrm{~d}, J_{C-P}=3.6\right), 157.0$.

$(\mathbf{d m a})_{3} \mathbf{P}=\mathbf{N}-(\mathbf{d m a})_{2} \mathbf{P}=\mathbf{N}-\mathbf{C}_{6} \mathbf{H}_{4}-\mathbf{2}-\mathbf{C l}(\mathbf{3 2 d})$. To the solution of $8.4 \mathrm{mmol}(1.3 \mathrm{~g})$ of $\left(\mathrm{Me}_{2} \mathrm{~N}\right)_{2} \mathrm{PCl}^{3}$ in 15 $\mathrm{ml}$ of benzene the solution of $8.3 \mathrm{mmol}(1.3 \mathrm{~g})$ of 2-chlorophenylazide ${ }^{7}$ in $10 \mathrm{~mL}$ of benzene was added under argon by means of syringe. The mixture was stirred and refluxed for $2 \mathrm{~h}$. To the warm solution $16.6 \mathrm{mmol}(2.96 \mathrm{~g}) \mathbf{2 8 a ^ { 1 \mathrm { c } }}$ dissolved in $3 \mathrm{~mL}$ of benzene was added and mixture was still heated for $2 \mathrm{~h}$. The solvent was distilled off and residue heated at $120{ }^{\circ} \mathrm{C}$ for $3 \mathrm{~h}$. Reddish-brown viscous oil was dissolved in $25 \mathrm{ml}$ of benzene, $\mathbf{2 8 a} \cdot \mathbf{H C l}$ was filtered off and solvent evaporated. Dark residue was dissolved in $70 \%$ aq. soln. of $\mathrm{EtNH}_{2}(20 \mathrm{~mL})$ and once recrystallized from the same solvent by adding to the solution water up the turbidity persisted. Beige crystals ( $1.0 \mathrm{~g}$ ) of the 32d free base were collected and once more recrystallized from hexane $\left(0.77 \mathrm{~g}\right.$, yield $22 \%$, mp $69.6-71.2{ }^{\circ} \mathrm{C}$. Anal. Calc. for $\mathrm{C}_{16} \mathrm{H}_{34} \mathrm{ClN}_{7} \mathrm{P}_{2}$ : C, 45.55\%; H, 8.12\%; N, 23.24\%. Found: C, 45.78\%; H, 8, 21\%; N, $23.50 \%$.

${ }^{1} \mathrm{H}$ NMR (200.13 MHz, THF) $\delta 2.55\left(\mathrm{~d}, 18 \mathrm{H}, J_{P-H}=10.1\right), 2.71\left(\mathrm{~d}, 12 \mathrm{H}, J_{P-H}=9.9\right) .{ }^{13} \mathrm{C}$ NMR $(50.32$ MHz, THF) $\delta 37.3\left(\mathrm{~d}, J_{C-P}=4.5\right), 37.9\left(\mathrm{~d}, J_{C-P}=3.2\right), 114.3,122.2\left(\mathrm{~d}, J_{C-P}=11.4\right), 126.7,129.4\left(\mathrm{~d}, J_{C-P}=\right.$ $2.5), 150.8\left(\mathrm{~d}, J_{C-P}=6.4\right)$. 
(pyrr) $)_{3} \mathbf{P}=\mathbf{N}-(\text { pyrr })_{2} \mathbf{P}=\mathbf{N}-\mathbf{E t}$ (33a). In a $50 \mathrm{~mL}$ two-neck flask $11 \mathrm{mmol}(0.9 \mathrm{~g})$ of dry $\mathrm{EtNH}_{2} \cdot \mathrm{HCl}$ and $3.6 \mathrm{mmol}(2 \mathrm{~g})$ of $\mathrm{Cl}-\mathrm{P}(\text { pyrr })_{2}=\mathrm{N}-\mathrm{P}^{+}(\text {pyrr })_{3} \cdot \mathrm{BF}_{4}^{-1 \mathrm{c}}$ were mixed in $20 \mathrm{~mL}$ of MeCN under Ar and 22 mmol (2.22 $\mathrm{g})$ of $\mathrm{Et}_{3} \mathrm{~N}$ was added at room temperature. The mixture was refluxed for $2 \mathrm{~h}$ and then cooled to $5{ }^{\circ} \mathrm{C}$. $\mathrm{Et}_{3} \mathrm{~N} \cdot \mathrm{HCl}$ was filtered off and solvent evaporated at reduced pressure. The residue was dissolved in $\mathrm{CH}_{2} \mathrm{Cl}_{2}$, washed with water, and organic phase was concentrated in vacuo. The oily residue was taken up in $\mathrm{MeOH}$, calculated amount of $\mathrm{NaBPh}_{4}$ in $\mathrm{MeOH}$ was added. The precipitated 33a $\cdot \mathbf{H B P h} \mathbf{4}_{4}$ was recrystallized from 1:10 MeCN/MeOH.Yield 35\% (1 g), mp $187-189{ }^{\circ} \mathrm{C}$. Anal. Calc. for $\mathrm{C}_{46} \mathrm{H}_{66} \mathrm{BN}_{7} \mathrm{P}_{2}$ : C, 69.95\%; H, 8.33\%; N, 12.41\%. Found: C, 69.31\%; H, 8.37\%; N,11.85\%. ${ }^{1} \mathrm{H}$ NMR (200.13 MHz, THF) $\delta 1.08\left(\mathrm{t}, 3 \mathrm{H}, J_{H-H}=7.1\right), 1.8(\mathrm{~m}, 20 \mathrm{H}$, overlapped by solvent), 2.88 (dq, 2H, $\left.J_{P-H}=10.5, J_{H-H}=7.1\right), 3.09(\mathrm{~m}, 20 \mathrm{H}), 6.69\left(\mathrm{t}, 4 \mathrm{H}, J_{H-H}=7.1\right), 6.84\left(\mathrm{t}, 8 \mathrm{H}, J_{H-H(a v)}=7.5\right), 7.26(\mathrm{~m}, 8 \mathrm{H})$. ${ }^{13} \mathrm{C}$ NMR (50.32 MHz, THF) $\delta 17.5,26.9-27.2(\mathrm{~m}), 36.6,47.5-47.8(\mathrm{~m}), 48.7\left(\mathrm{~d}, J_{C-P}=4.8\right), 121.7$, $125.6(\mathrm{~m}, 2.9), 137.2,165.3\left(\mathrm{~m}, J_{B-C}=49.4\right)$.

The sample of $\mathbf{3 3 a} \cdot \mathbf{H B F}_{4}$ was prepared via the ion exchange of $\mathrm{BPh}_{4}{ }^{-}$for $\mathrm{Cl}^{-}$by means of Dowex Monosphere 550A in $\mathrm{MeCN} / \mathrm{MeOH}$ solution followed the treatment of separated $\mathbf{3 3 a} \cdot \mathbf{H C l}$ with $\mathrm{NaBF}_{4}$ in $70 \% \mathrm{EtNH}_{2}$ aq soln and recrystallization of the product from the same solvent ${ }^{1 \mathrm{c}}, \mathrm{mp} 65.2-66.2{ }^{\circ} \mathrm{C}$.

A sample of free base was prepared according to the general procedure from $\mathrm{HBPh}_{4}$ salt to give white soft crystals. ${ }^{1} \mathrm{H}$ NMR (200.13 MHz, THF) $\delta 0.99\left(\mathrm{dt}, 3 \mathrm{H}, J_{P-H}=1.5, J_{H-H}=7.1\right), 1.8(\mathrm{~m}, 20 \mathrm{H}$, overlapped by solvent), $3.05\left(\mathrm{dq}, 2 \mathrm{H}, J_{P-H}=10.3, J_{H-H}=7.1\right), 3.12(\mathrm{~m}, 8 \mathrm{H}), 3.21(\mathrm{~m}, 12 \mathrm{H}) .{ }^{13} \mathrm{C} \mathrm{NMR}$ $(50.32 \mathrm{MHz}, \mathrm{THF}) \delta 22.2\left(\mathrm{dd}, J_{C-P}=19.5, J_{C-P}=1.8\right), 27.1\left(\mathrm{~d}, J_{C-P}=7.6\right), 27.3\left(\mathrm{~d}, J_{C-P}=7.3\right), 40.0\left(\mathrm{~d}, J_{C-}\right.$ $\left.{ }_{P}=2.4\right), 47.4\left(\mathrm{~d}, J_{C-P}=4.4\right), 48.1\left(\mathrm{~d}, J_{C-P}=2.8\right)$.

(pyrr) $)_{3} \mathbf{P}=\mathbf{N}$-(pyrr) $)_{2} \mathbf{P}=\mathbf{N}-\mathbf{C}_{6} \mathbf{H}_{\mathbf{4}}-\mathbf{4}-\mathbf{B r}(\mathbf{3 3 b})$. In $18 \mathrm{~mL} \mathrm{1:2} \mathrm{mixture} \mathrm{of} \mathrm{THF/MeCN} 2.6 \mathrm{mmol}(1.3 \mathrm{~g})$ of phosphonium salt $\mathrm{Cl}-\mathrm{P}(\text { pyrr })_{2} \mathrm{~N}=\mathrm{P}^{+}(\text {pyrr })_{3} \cdot \mathrm{BF}_{4}^{-1 \mathrm{c}}$ and $4.3 \mathrm{mmol}(0.74 \mathrm{~g})$ of 4-bromoaniline were dissolved. To the solution $2.36 \mathrm{mmol}(0.24 \mathrm{~g})$ of $\mathrm{Et}_{3} \mathrm{~N}$ was added and mixture was refluxed for $20 \mathrm{~h}$. The solvent was distilled off and residue heated still at $120{ }^{\circ} \mathrm{C}$ for $8 \mathrm{~h}$. The brown oily substance was 
dissolved in dichloromethane and washed three times with acidified water. The $\mathrm{CH}_{2} \mathrm{Cl}_{2}$ was evaporated, the residue dissolved in $\mathrm{MeOH}$ and $1.9 \mathrm{mmol}$ of $\mathrm{NaBPh}_{4}$ in $\mathrm{MeOH}$ was added. The precipitate was washed three times with warm 5:1 mixture and recrystallized from 1:1 mixture of $\mathrm{MeOH} / \mathrm{MeCN}$ to give $0.24 \mathrm{~g}$ of transparent beige tint crystals of $\mathbf{3 3 b} \cdot \mathbf{H B P h}$ (yield $11 \%$, not optimized, mp $205.2-206.4$ $\left.{ }^{\circ} \mathrm{C}\right)$. Anal. Calc. for $\mathrm{C}_{50} \mathrm{H}_{65} \mathrm{BBrN}_{7} \mathrm{P}_{2}$ : C, 65.51\%; H, 7.15\%; N, 10.69\%. Found: C, 65.20\%; H, 7.13\%.; N,10.63\%. ${ }^{1} \mathrm{H}$ NMR (200.13 MHz, $\left.\mathrm{CDCl}_{3}\right) \delta 1.74(\mathrm{~m}, 20 \mathrm{H}), 2.95(\mathrm{~m}, 20 \mathrm{H}), 4.58\left(\mathrm{~d}, 1 \mathrm{H}, J_{P-H}=11.0\right)$, $6.47\left(\mathrm{~d}, 2 \mathrm{H}, J_{H-H}=8.8\right), 6.88\left(\mathrm{t}, 4 \mathrm{H}, J_{H-H}=7.3\right), 7.02\left(\mathrm{t}, 8 \mathrm{H}, J_{H-H(a v)}=7.5\right), 7.24\left(\mathrm{~d}, 2 \mathrm{H}, J_{H-H}=8.8\right), 7.40$ $(\mathrm{m}, 8 \mathrm{H}) .{ }^{13} \mathrm{C} \mathrm{NMR}\left(50.32 \mathrm{MHz}, \mathrm{CDCl}_{3}\right) \delta 26.3\left(\mathrm{~d}, J_{C-P}=8.8\right), 26.4\left(\mathrm{~d}, J_{C-P}=9.4\right), 46.8\left(\mathrm{~d}, J_{C-P}=5.1\right)$, $47.0\left(\mathrm{~d}, J_{C-P}=5.6\right), 115.1,120.4\left(\mathrm{~d}, J_{C-P}=6.9\right), 121.6,125.4,132.1,136.4,138.2,164.4\left(\mathrm{~m}, J_{C-B}=49.4\right)$. A sample of the free base was prepared according to the general procedure to give colorless crystals. ${ }^{1} \mathrm{H}$ NMR (200.13 MHz, THF) $\delta 1.8\left(\mathrm{~m}, 20 \mathrm{H}\right.$, overlapped by solvent), $3.13(\mathrm{~m}, 20 \mathrm{H}), 6.51\left(\mathrm{dd}, 2 \mathrm{H}, J_{P \text { - }}\right.$ $\left.{ }_{H}=0,8, J_{H-H}=8.8\right), 6.87\left(\mathrm{dd}, 2 \mathrm{H}, J_{P-H}=1.3, J_{H-H}=8.8\right) .{ }^{13} \mathrm{C} \mathrm{NMR}(50.32 \mathrm{MHz}, \mathrm{THF}) \delta 27.0\left(\mathrm{~d}, J_{C-P}=\right.$ 8.1), $27.3\left(\mathrm{~d}, J_{C-P}=8.4\right), 47.4\left(\mathrm{~d}, J_{C-P}=4.7\right), 47.9\left(\mathrm{~d}, J_{C-P}=3.8\right), 105.0,124.3\left(\mathrm{~d}, J_{C-P}=21.4\right), 131.1(\mathrm{~d}$, $\left.J_{C-P}=2.2\right), 154.7$

$\left[(\mathbf{d m a})_{3} \mathbf{P}=\mathbf{N}\right]_{3} \mathbf{P}=\mathbf{N}-\mathbf{P h}(\mathbf{3 9 c})$. This base was synthesized by one of us (T.R.) at Prof. R. Schwesinger's laboratory (University of Freiburg). To $13.3 \mathrm{mmol}(0.55 \mathrm{~g})$ of $\mathrm{KH} 20 \mathrm{~mL}$ of aniline was added through the septum by means of syringe under a flow of $\mathrm{N}_{2}$. The phosphonium salt ${ }^{1 \mathrm{c}}\left[(\mathrm{dma})_{3} \mathrm{P}=\mathrm{N}\right]_{3} \mathrm{P}^{+} \mathrm{Cl} \mathrm{PF}_{6}^{-}$ ( $5.5 \mathrm{mmol}, 4.1 \mathrm{~g}$ ) was slowly added by means of a powder addition system at room temperature. The mixture was stirred for $3 \mathrm{~h}$ and was left standing overnight. The solution was treated with diluted solution of hydrochloric acid. The aqueous and organic layers were separated and the organic phase was concentrated at reduced pressure. The dark residue $(5 \mathrm{~g})$ was treated with $60 \mathrm{~mL}$ of $70 \%$ aq soln of $\mathrm{EtNH}_{2}$, about $20 \mathrm{~mL}$ of water was slowly added and the solution was left aside for crystallization. The precipitate was filtered off and recrystallized once more from $70 \%$ aq soln of $\mathrm{EtNH}_{2}$ in the same way. 
Colorless crystals of $\mathbf{3 9} \mathbf{c} \cdot \mathbf{H P F}_{\mathbf{6}}\left(2.4 \mathrm{~g}\right.$, yield $54 \%$, mp $\left.169-172^{\circ} \mathrm{C}\right)$ were collected. Anal: Calcd. for $\mathrm{C}_{24} \mathrm{H}_{60} \mathrm{~F}_{6} \mathrm{~N}_{13} \mathrm{P}_{5}: \mathrm{C}, 36.05 \% ; \mathrm{H}, 7.56 \%$; , 22.77\%. Found: C, 35.96\%; H,7.52\%; N, $22.78 \%$.

For liberation of the free base, its $\mathrm{HBF}_{4}$ salt was first prepared. The anion exchange resin Lewatit 500 was used to change $\mathrm{PF}_{6}^{-}$anion for $\mathrm{Cl}^{-}$(solvent $\mathrm{MeOH}$ ). The following treatment with aq soln of $\mathrm{NaBF}_{4}$ and recrystallization of this salt from $70 \%$ aq soln of $\mathrm{EtNH}_{2}$ gave pure $\mathbf{3 9 c} \cdot \mathbf{H B F}_{\mathbf{4}}, \mathrm{mp}$ 167.1-168.4 ${ }^{\circ} \mathrm{C}$. ${ }^{1} \mathrm{H}$ NMR $(200.13 \mathrm{MHz}, \mathrm{THF}) \delta 2.66\left(\mathrm{~d}, 54 \mathrm{H}, J_{P-H}=10.1\right), 5.60\left(\mathrm{~d}, 1 \mathrm{H}, J_{P-H}=9.6\right), 6.67\left(\mathrm{dt}, 1 \mathrm{H}, J_{H-H}=\right.$ 6.6, $\left.J_{H-H}=1.6\right), 7.0-7.2(\mathrm{~m}, 4 \mathrm{H}) .{ }^{13} \mathrm{C} \mathrm{NMR}(50.32 \mathrm{MHz}, \mathrm{THF}) \delta 37.5\left(\mathrm{~d}, J_{C-P}=4.7\right), 118.5\left(\mathrm{~d}, J_{C-P}=7.3\right)$, $119.5,128.9,144.6$.

A sample of the free base was prepared from the $\mathrm{HBF}_{4}$ salt according to the general procedure to give colorless crystals. ${ }^{1} \mathrm{H}$ NMR $(200.13 \mathrm{MHz}, \mathrm{THF}) \delta 2.66\left(\mathrm{~d}, 54 \mathrm{H}, J_{P-H}=10.0\right), 5.94\left(\mathrm{dt}, 1 \mathrm{H}, J_{H-H}=6.8, J_{H-}\right.$ $\left.{ }_{H}=1.5\right), 6.66\left(\mathrm{ddd}, 2 \mathrm{H}, J_{H-H}=6.8, J_{H-H}=8.7, J_{P-H}=1.2\right), 6.77\left(\mathrm{ddd}, 2 \mathrm{H}, J_{H-H}=8.7, J_{H-H}=1.5, J_{P-H}=0.7\right)$. ${ }^{13} \mathrm{C}$ NMR (50.32 MHz, THF) $\delta 38.0\left(\mathrm{~d}, J_{C-P}=3.8\right), 109.7,121.7\left(\mathrm{~d}, J_{C-P}=24.0\right), 127.8\left(\mathrm{~d}, J_{C-P}=2.7\right)$, 157.9 .

$\left[(\mathbf{d m a})_{3} \mathbf{P}=\mathbf{N}\right]_{3} \mathbf{P}=\mathbf{N}-\mathrm{C}_{6} \mathrm{H}_{4}-4-O M e$ (39d). This compound was prepared as described for 40a. Phosphonium salt $\left[(\mathrm{dma})_{3} \mathrm{P}=\mathrm{N}-\right]_{3} \mathrm{P}^{+} \mathrm{Cl}_{,} \mathrm{Cl}^{-}$was synthesized from $8.2 \mathrm{mmol}(1.7 \mathrm{~g})$ of $\mathrm{PCl}_{5}$ and $49 \mathrm{mmol}$ $(8.7 \mathrm{~g})$ of $\mathbf{2 8 \mathbf { a } ^ { 1 \mathrm { c } }}$ in chlorobenzene. To the solvent-free residue $5.3 \mathrm{~g}$ of 4-methoxyaniline was added, the reaction flask was connected to rotary evaporator and heated under argon atmosphere at $85-90{ }^{\circ} \mathrm{C}$ for $6 \mathrm{~h}$. The excess of 4-methoxyaniline and other volatile components were distilled off at reduced pressure (0.5 Torr). The distillation residue (about $7 \mathrm{~g}$ ) was dissolved in $70 \%$ aq soln of $\mathrm{EtNH}_{2}$, extracted with diethylether, and to aq layer $10 \mathrm{mmol}(1.1 \mathrm{~g})$ of $\mathrm{NaBF}_{4}$ in small quantity of water was added. Formed $\mathrm{HBF}_{4}$ salt was extracted with dichloromethane, solvent removed and the residue dissolved in methanol. To the methanolic solution $7.6 \mathrm{mmol}(2.6 \mathrm{~g})$ of $\mathrm{NaBPh}_{4}$ was added. Raw 39d·HBPh 4 was twice recrystallized from 1:15 mixture of $\mathrm{MeCN} / \mathrm{MeOH}$. Yield 23\% (1.8 g) of 
colorless crystals, mp $124.8-125.7{ }^{\circ} \mathrm{C}$. Anal. Calc. for $\mathrm{C}_{49} \mathrm{H}_{82} \mathrm{BN}_{13} \mathrm{OP}_{4}: \mathrm{C}, 58.62 \% ; \mathrm{H}, 8.23 \%$; $\mathrm{N}$, 18.10\%. Found: C, 58.80\%; H, 8.46\%; N, 18.60\%. ${ }^{1} \mathrm{H}$ NMR $(200.13 \mathrm{MHz}, \mathrm{THF}) \delta 2.59\left(\mathrm{~d}, 54 \mathrm{H}, J_{P-H}=\right.$ 10.0), 3.6 (s, 3H, overlapped by solvent), $4.93\left(\mathrm{~d}, 1 \mathrm{H}, J_{P-H}=8.7\right), 6.65-6.75(\mathrm{~m}, 6 \mathrm{H}), 6.84\left(\mathrm{t}, 8 \mathrm{H}, J_{H-}\right.$ $H(a v)=7.3), 6.95\left(\mathrm{~d}, 2 \mathrm{H}, J_{H-H}=8.9\right), 7.27(\mathrm{~m}, 8 \mathrm{H}) .{ }^{13} \mathrm{C} \mathrm{NMR}(50.32 \mathrm{MHz}, \mathrm{THF}) \delta 37.5\left(\mathrm{~d}, J_{C-P}=4.5\right)$, $55.6,114.7,120.0\left(\mathrm{~d}, J_{C-P}=6.7\right), 121.7,125.6\left(\mathrm{~m}, J_{B-C}=2.9\right), 137.2\left(\mathrm{~m}, J_{B-C}=1.5\right), 137.4\left(\mathrm{~d}, J_{C-P}=0.9\right)$, $154.9,165.2\left(\mathrm{~m}, J_{B-C}=49.6\right)$.

A sample of the free base was prepared according to the general procedure to give colorless crystals. ${ }^{1} \mathrm{H}$ NMR (200.13 MHz, THF) $\delta 2.66\left(\mathrm{~d}, 54 \mathrm{H}, J_{P-H}=10.0\right), 3.6$ (s, 3H, overlapped by solvent), 6.36, $\left(\mathrm{dd}, 2 \mathrm{H}, J_{P-H}=1.3, J_{H-H}=9.0\right), 6.70\left(\mathrm{dd}, 2 \mathrm{H}, J_{P-H}=0.9, J_{H-H}=9.0\right) .{ }^{13} \mathrm{C} \mathrm{NMR}(50.32 \mathrm{MHz}, \mathrm{THF}) \delta 38.0$ $\left(\mathrm{d}, J_{C-P}=3.9\right), 56.3\left(\mathrm{~d}, J_{C-P}=2.3\right), 114.5\left(\mathrm{~d}, J_{C-P}=2.4\right), 121.2\left(\mathrm{~d}, J_{C-P}=23.5\right), 148.1,\left(\mathrm{~d}, J_{C-P}=2.7\right)$.

$\left[(\text { pyrr })_{3} \mathbf{P}=\mathbf{N}\right]_{3} \mathbf{P}=\mathbf{N}-\mathbf{P h}(\mathbf{4 0 a})$. To $15 \mathrm{~mL}$ of chlorobenzene $5.2 \mathrm{mmol}(1.08 \mathrm{~g})$ of $\mathrm{PCl}_{5}$ and $31.2 \mathrm{mmol}$ $(8.14 \mathrm{~g})$ of $\mathbf{3 0 a ^ { 1 \mathrm { c } }}$ were added while stirring under argon flow at $-30^{\circ} \mathrm{C}$. The temperature was allowed to rise to room temperature and the mixture was stirred for additional $3 \mathrm{~h}$. Chlorobenzene was removed at reduced pressure and $15 \mathrm{~mL}$ of $\mathrm{THF}$ was added to the residue to precipitate most of the formed 30a·HCl. It was filtered off and the solvent was evaporated. $\left({ }^{31} \mathrm{P}\right.$ NMR spectrum showed that the mixture contained beside the phosphonium salt still $6.8 \mathrm{mmol}$ of $\mathbf{3 0 a} \cdot \mathbf{H C l}$ ). To the residue $5 \mathrm{~mL}$ of aniline was added, the mixture was heated slowly up to $80{ }^{\circ} \mathrm{C}$ and kept at that temperature for $5 \mathrm{~h}$. The cooled mixture was worked up with a solution of $6.5 \mathrm{mmol}$ of $\mathrm{MeOK}$ in $4 \mathrm{~mL}$ of dry $\mathrm{MeOH}$. Solvents (aniline, $\mathrm{MeOH}$ ) and the free 30a base were distilled off at reduced pressure $\left(135^{\circ} \mathrm{C} / 0.05\right.$ Torr $)$, and the residue was dissolved in $20 \mathrm{~mL}$ of $70 \%$ aq soln of $\mathrm{EtNH}_{2}$. The solution was filtered and $5.9 \mathrm{mmol}(0.65$ g) of $\mathrm{NaBF}_{4}$ in water was added. To the slightly warm clear solution water was added until turbidity persisted. After standing overnight the crystals of $\mathbf{4 0 a} \cdot \mathbf{H B F} \mathbf{F}_{\mathbf{4}}$ were collected and recrystallized from 1:4 mixture of hexane/ethanol (yield 23\%, $1 \mathrm{~g}$, not optimized, $\mathrm{mp} \leq 182{ }^{\circ} \mathrm{C}$, decomp.). Anal. Calc. for $\mathrm{C}_{42} \mathrm{H}_{77} \mathrm{BF}_{4} \mathrm{~N}_{13} \mathrm{P}_{4}:$ C, 51.69\%; H, 7.95\%; N, 18.66\%, Found; C, 51.97\%; H, 8.13\%; N, 19.03\%. MS 
(ESI): m/z $888\left(\mathrm{M}^{+}\right) .{ }^{1} \mathrm{H}$ NMR $(200.13 \mathrm{MHz}, \mathrm{THF}) \delta 1.8(\mathrm{~m}, 36 \mathrm{H}$, overlapped by solvent), 3.20 (dt, $\left.36 \mathrm{H}, J_{P-H}=3.6, J_{H-H}=6.6\right), 5.5\left(\mathrm{~d}, 1 \mathrm{H}, J_{P-H}=9.2\right), 6.64\left(\mathrm{dt}, 1 \mathrm{H}, J_{H-H}=6.6, J_{H-H}=1.7\right), 7.0-7.2(\mathrm{~m}, 4 \mathrm{H})$. ${ }^{13} \mathrm{C}$ NMR (50.32 MHz, THF) $\delta 27.0\left(\mathrm{~d}, J_{C-P}=8.9\right), 47.5\left(\mathrm{~d}, J_{C-P}=4.7\right), 118.3\left(\mathrm{~d}, J_{C-P}=7.3\right), 119.2$, $128.9,144.8$.

A sample of the free base was prepared according to the general procedure to give nearly colorless crystals. ${ }^{1} \mathrm{H}$ NMR $\left(200.13 \mathrm{MHz}, \mathrm{C}_{6} \mathrm{D}_{6}\right) \delta 1.68(\mathrm{~m}, 36 \mathrm{H}), 3.35\left(\mathrm{dt}, 36 \mathrm{H}, J_{P-H}=4.0, J_{H-H}=6.6\right), 6.66(\mathrm{dt}$, $\left.1 \mathrm{H}, J_{H-H}=6.6, J_{H-H}=1.6\right), 7.1-7.5(\mathrm{~m}, 4 \mathrm{H}) .{ }^{13} \mathrm{C} \mathrm{NMR}\left(50.32 \mathrm{MHz}, \mathrm{C}_{6} \mathrm{D}_{6}\right) \delta 26.8\left(\mathrm{~d}, J_{C-P}=8.4\right), 47.1(\mathrm{~d}$, $\left.J_{C-P}=4.4\right), 109.9,121.6\left(\mathrm{~d}, J_{C-P}=24.7\right), 128.1,158.2\left(\mathrm{~d}, J_{C-P}=3.1\right)$.

$\left[(\text { pyrr) })_{3} \mathbf{P}=\mathbf{N}\right]_{3} \mathbf{P}=\mathbf{N}-\mathbf{C}_{6} \mathbf{H}_{4}-4-O M e(40 b) .\left[(\text { pyrr })_{3} \mathrm{P}=\mathrm{N}\right]_{3} \mathrm{P}^{+} \mathrm{Cl}, \mathrm{Cl}^{-}$was prepared from 9 mmol of $\mathrm{PCl}_{5}$ and $54 \mathrm{mmol}$ of $\mathbf{3 0 a}$ in $22 \mathrm{~mL}$ of chlorobenzene as described above for compound 40a. After working up with THF and concentrating of filtrate the residue, according to ${ }^{31} \mathrm{P}$ NMR spectrum, still contained $9 \mathrm{mmol}$ of $\mathbf{3 0 a}$ and $1.8 \mathrm{mmol}$ of its $\mathrm{HCl}$ salt. This residue was dissolved in $15 \mathrm{~mL}$ of dichloromethane, $8.6 \mathrm{~g}$ of 4-methoxyaniline dissolved in $13 \mathrm{~mL}$ of dichloromethane was added and the solvent removed. The mixture was heated at $80{ }^{\circ} \mathrm{C}$ for $4 \mathrm{~h}$ and allowed to cool to room temperature. It was taken up in 4 $\mathrm{mL}$ of $\mathrm{MeOH}$, and $2 \mathrm{mmol}$ of $\mathrm{MeOK}$ solution in $\mathrm{MeOH}$ was added. Excess of 4-methoxyaniline, 30a and other volatiles were distilled off (finally at $172{ }^{\circ} \mathrm{C} / 0.03$ Torr). The residue was dissolved in $40 \mathrm{ml}$ of $70 \%$ aq soln of $\mathrm{EtNH}_{2}, 9 \mathrm{mmol}(1 \mathrm{~g})$ of $\mathrm{NaBF}_{4}$ solution in $5 \mathrm{~mL}$ of water was added and then more water until turbidity persisted (about $12 \mathrm{~mL}$ ). The next day the crystals of $\mathbf{4 0 b} \cdot \mathbf{H B F} \mathbf{F}_{\mathbf{4}}$ salt were filtered off and recrystallized from 1:3 mixture of hexane/ethyl acetate to give $3.4 \mathrm{~g}$ colorless crystals (yield $37 \%$, mp $153-155^{\circ} \mathrm{C}$ ). Anal. Calc. for $\mathrm{C}_{43} \mathrm{H}_{80} \mathrm{BF}_{4} \mathrm{~N}_{13} \mathrm{OP}_{4}: \mathrm{C}, 51.34 \% ; \mathrm{H} ; 8.01 \%$; ; 18.10\%. Found: C, 51,56\%; H; 8.26\%; N; 18.42\%. MS (ESI): m/z $918\left(\mathrm{M}^{+}\right) .{ }^{1} \mathrm{H}$ NMR $\left(200.13 \mathrm{MHz}, \mathrm{CDCl}_{3}\right) \delta 1.78$ $(\mathrm{m}, 36 \mathrm{H}), 3.13\left(\mathrm{dt}, 36 \mathrm{H}, J_{P-H}=3.3, J_{H-H}=6.6\right), 3.75(\mathrm{~s}, 3 \mathrm{H}), 4.80,\left(\mathrm{~d}, 1 \mathrm{H}, J_{P-H}=7.8\right), 6.72\left(\mathrm{~d}, 2 \mathrm{H}, J_{H-H}=\right.$ 8.9), $6.90\left(\mathrm{~d}, 2 \mathrm{H}, J_{H-H}=8.9\right) .{ }^{13} \mathrm{C} \mathrm{NMR}\left(50.32 \mathrm{MHz}, \mathrm{CDCl}_{3}\right) \delta 26.3\left(\mathrm{~d}, J_{C-P}=8.8\right), 46.7\left(\mathrm{~d}, J_{C-P}=4.8\right)$, $55.9,114.2,118.7,\left(\mathrm{~d}, J_{C-P}=6.9\right), 137.1\left(\mathrm{~d}, J_{C-P}=1.6\right), 153.4$. 
A sample of the free base was prepared according to the general procedure to give colorless crystals.

${ }^{1} \mathrm{H}$ NMR $(200.13 \mathrm{MHz}, \mathrm{THF}) \delta 1.8\left(\mathrm{~m}, 36 \mathrm{H}\right.$, overlapped by solvent), $3.26\left(\mathrm{dt}, 36 \mathrm{H}, J_{P-H}=4.3, J_{H-H}=\right.$ 6.6), 3.7 (s, 3H, overlapped by solvent), $6.33\left(\mathrm{dd}, 2 \mathrm{H}, J_{P-H}=1.3, J_{H-H}=8.9\right), 6.62\left(\mathrm{~d}, 2 \mathrm{H}, J_{H-H}=8.9\right) .{ }^{13} \mathrm{C}$ $\operatorname{NMR}(50.32 \mathrm{MHz}, \mathrm{THF}) \delta 27.1\left(\mathrm{~d}, J_{C-P}=8.3\right), 47.5\left(\mathrm{~d}, J_{C-P}=4.4\right), 56.6,114.6\left(\mathrm{~d}, J_{C-P}=2.4\right), 121.0(\mathrm{~d}$, $\left.J_{C-P}=24.2\right), 147.8,153.1$.

$\left[(\text { pyrr })_{3} \mathbf{P}=\mathbf{N}\right]_{3} \mathbf{P}=\mathbf{N}-\mathbf{C}_{6} \mathbf{H}_{4}-\mathbf{4}-\mathbf{B r} \quad$ (40c). $\mathrm{Me}_{3} \mathrm{SiN}=\mathrm{P}(\text { pyrr })_{3}$, prepared $^{9}$ from $15 \mathrm{mmol}(2.86 \mathrm{~g})$ of $\mathrm{Me}_{3} \mathrm{SiCCl}_{3}$ and $15 \mathrm{mmol}(3.8 \mathrm{~g}$ ) of $\mathbf{3 0 a}$ was dissolved in $3 \mathrm{~mL}$ of toluene and added by means of a syringe to a solution of $14 \mathrm{mmol}(1.9 \mathrm{~g})$ of $\mathrm{PCl}_{3}$ in $3 \mathrm{~mL}$ of toluene. The mixture was stirred at room temperature for half an hour, and then the $\mathrm{Me}_{3} \mathrm{SiCl}$ and toluene were removed under reduced pressure. To the warm residue $11.25 \mathrm{mmol}$ (2.22 $\mathrm{g})$ of 4-bromophenylazide ${ }^{7}$ was added followed $32.5 \mathrm{mmol}(8.3$ g) of 30a elevating at the same time temperature of the mixture up to $115{ }^{\circ} \mathrm{C}$ and hold it for $8 \mathrm{~h}$. The cooled reaction mixture was taken up in $15 \mathrm{~mL}$ of THF, filtered and filtrate concentrated (finally at 80 ${ }^{\circ} \mathrm{C} / 3$ Torr). The residue was dissolved in $80 \mathrm{~mL}$ of $70 \%$ aq soln of $\mathrm{EtNH}_{2}$ and to the warm solution 1.1 $\mathrm{g} \mathrm{NaBF}_{4}$ and $11 \mathrm{~mL}$ of water was slowly added. Collected light beige precipitate was recrystallized from ethyl acetate to give $1.7 \mathrm{~g}$ (yield $14 \%$, not optimized) of $\mathbf{4 0 c} \cdot \mathbf{H B F}_{\mathbf{4}}$ crystals, $\mathrm{mp} 195.9-196.8^{\circ} \mathrm{C}$. Anal. Calc. for $\mathrm{C}_{42} \mathrm{H}_{77} \mathrm{BrBF}_{4} \mathrm{~N}_{13} \mathrm{P}_{4}$ : C, 47.83\%; H; 7.26\%; N; 17.26\%. Found: C; 47.91\%\%; H; 7.50\%; N, 17.59\%. MS (ESI): m/z $968\left(\mathrm{M}^{+}, 100 \%\right) .{ }^{1} \mathrm{H}$ NMR $\left(200.13 \mathrm{MHz}, \mathrm{CDCl}_{3}\right) \delta 1.78(\mathrm{~m}, 36 \mathrm{H}), 3.12(\mathrm{dt}$, $\left.36 \mathrm{H}, J_{P-H}=3.5, J_{H-H}=6.6\right), 5.15\left(\mathrm{~d}, 1 \mathrm{H}, J_{P-H}=8.9\right), 6.87\left(\mathrm{~d}, 2 \mathrm{H}, J_{H-H}=8.8\right), 7.22\left(\mathrm{~d}, 2 \mathrm{H}, J_{H-H}=8.8\right) .{ }^{13} \mathrm{C}$ $\operatorname{NMR}\left(50.32 \mathrm{MHz}, \mathrm{CDCl}_{3}\right) \delta 26.3\left(\mathrm{~d}, J_{C-P}=8.7\right), 46.7\left(\mathrm{~d}, J_{C-P}=4.8\right), 110.9,118.6\left(\mathrm{~d}, J_{C-P}=7.1\right), 131.3$, 142.7.

A sample of the free base was prepared according to the general procedure to give colorless crystals. ${ }^{1} \mathrm{H}$ NMR (200.13 MHz, THF) $\delta 1.8\left(\mathrm{~m}, 36 \mathrm{H}\right.$, overlapped by solvent), $3.25\left(\mathrm{dt}, 36 \mathrm{H}, J_{P-H}=4.0, J_{H-H}=\right.$ 6.6), $6.64(\mathrm{~m}, 4 \mathrm{H}) .{ }^{13} \mathrm{C}$ NMR (50.32 MHz, THF) $\delta 27.1\left(\mathrm{~d}, J_{C-P}=8.4\right), 47.5\left(\mathrm{~d}, J_{C-P}=4.4\right), 99.6,122.9(\mathrm{~d}$, $\left.J_{C-P}=24.8\right), 130.2\left(\mathrm{~d}, J_{C-P}=2.7\right), 157.3\left(\mathrm{~d}, J_{C-P}=3.6\right)$. 


\section{References for Synthesis and Liberation Procedures}

1. (a) Schwesinger, R.; Schlemper, H. Angew. Chem., 1987, 99, 1212-1214 and ref. cited therein;

(b) Schwesinger, R.; Willaredt, J.; Schlemper, H.; Keller, M.; Schmitt, D.; Fritz, H. Chem. Ber. 1994, 127, 2435-2454 and ref. cited therein; (c) Schwesinger, R. et al Liebigs Ann. 1996, 10551081.

2. Schwesinger, R.; Schlemper, H. Angew. Chem. Int. Ed. Engl. 1987, 26, 1167 - 1169.

3. (a) Nöth, H.; Vetter, H.-J. Chem. Ber. 1963, 96, 1109 - 1119. (b) Vetter, H.-J.; Nöth, H. Chem. Ber. 1963, 96, 1308-1315

4. (a) Raab, V.; Kipke, J.; Gschwind, R.M.; Sundermeyer, J. J. Chem. Eur. J. 2002, 1682-1692; (b) Raab, V.; Harms, K.; Sundermeyer, J.; Kovačević, B.; Maksić, Z. J. Org. Chem. 2003, 87908797.

5. Kaljurand I.; Kütt, A.; Sooväli, L.; Rodima, T.; Mäemets, V.; Leito, I.; Koppel, I. A. J. Org. Chem. 2005, 70, 1019-1028.

6. Lindsay, R. O.; Allen, C. F. H. Org. Synthesis; Wiley: New York, 1955, Collect. Vol III, p 710.

7. Spauschus, H. O.; Scott, J. M. J. Am. Chem. Soc.1951, 73, $208-210$.

8. Perrin, D. D.; Armarego, W. L. F. Purification of Laboratory Chemicals, Pergamon Press: New York, 1988.

9. Marchenko, A. P.; Bespalko, G. K.; Koidan, G. N.; Pinchuk, A. M.; Zh. Obsch. Khim. 1983, 53, $1436-1437$. 
Table S1. Ionic radii of the protonated forms of the bases included in present work and the ionic radii of the methanesulfonate and tetrafluoroborate anions.

\begin{tabular}{llll}
\hline Ion & $\begin{array}{l}\text { Ion-pair } \\
\text { radius, } \AA^{a}\end{array}$ & Ion & $\begin{array}{l}\text { Ion-pair } \\
\text { radius, } \AA^{a}\end{array}$ \\
\hline $\begin{array}{llll}(\mathrm{tmg})_{3} \mathrm{P}=\mathrm{NRH}^{+} ; \\
{\left[(\mathrm{dma})_{3} \mathrm{P}=\mathrm{N}\right]_{3} \mathrm{P}=\mathrm{NRH}^{+}}\end{array}$ & 5.5 & $\mathrm{TMGNH}^{+}$ & 4.7 \\
$\left(\mathrm{R}^{\prime}\right)(\mathrm{tmg})_{2} \mathrm{P}=\mathrm{NRH}^{+}$ & 4.9 & {$\left[(\mathrm{dma})_{3} \mathrm{P}=\mathrm{N}\right](\mathrm{dma})_{2} \mathrm{P}=\mathrm{NRH}^{+}$} & 4.8 \\
$\left(\mathrm{R}^{\prime}\right)_{2}(\mathrm{tmg}) \mathrm{P}=\mathrm{NRH}^{+}$ & 4.5 & $(\mathrm{pyrr})_{3} \mathrm{P}=\mathrm{NRH}^{+}$ & 4 \\
{$\left[(\mathrm{pyrr})_{3} \mathrm{P}=\mathrm{N}\right]_{3} \mathrm{P}=\mathrm{NRH}^{+}$} & 6.6 & $\begin{array}{l}(\mathrm{dma})_{3} \mathrm{P}=\mathrm{NRH}^{+} ; \\
(\mathrm{dma})_{2}(\mathrm{Me}) \mathrm{P}=\mathrm{NRH}^{+}\end{array}$ & 4 \\
{$\left[(\mathrm{pyrr})_{3} \mathrm{P}=\mathrm{N}\right]_{2}(\mathrm{pyrr}) \mathrm{P}=\mathrm{NRH}^{+} ;$} & 6 & $\mathrm{CH}_{3} \mathrm{SO}_{3}{ }^{-} ; \mathrm{DBUH}^{+}$ & 2.5 \\
{$\left[(\mathrm{pyrr})_{3} \mathrm{P}=\mathrm{N}\right]_{2}(\mathrm{R}) \mathrm{P}=\mathrm{NRH}^{+}$} & & & 3 \\
{$\left[(\mathrm{dma})_{3} \mathrm{P}=\mathrm{N}\right]_{2}(\mathrm{dma}) \mathrm{P}=\mathrm{NRH}^{+} ;$} & 5 & $\mathrm{MTBDH}^{+}$ & 2 \\
{$\left[(\mathrm{dma})_{3} \mathrm{P}=\mathrm{N}\right]_{2}\left(\mathrm{R}^{\prime}\right) \mathrm{P}=\mathrm{NRH}^{+}$} & & & 2 \\
{$\left[(\mathrm{pyrr})_{3} \mathrm{P}=\mathrm{N}\right]_{(\mathrm{pyrr})_{2} \mathrm{P}=\mathrm{NRH}^{+}}$} & 5.4 & $\mathrm{BF}_{4}^{-}$ & 2 \\
\hline
\end{tabular}

\footnotetext{
${ }^{a}$ Ionic radii from previous works (refs 1,2). In cases when no data were available, the radii were estimated by PM3 calculations; $\mathrm{R}=$ alkyl, aryl or $\mathrm{H} ; \mathrm{R}^{\prime}=\mathrm{dma}$ or $\mathrm{NEt}_{2}$. TMGN denotes N",N"'naphthalene-1,8-diylbis(N,N, N', N'-tetramethylguanidine), MTBD denotes 1,3,4,6,7,8-hexahydro-1methyl-2H-pyrimido[1,2-a]pyrimidine and DBU denotes 1,8-diazabicyclo[5.4.0]undec-7-ene.
} 


\section{Details of the UV-Vis Spectrophotometric Measurement Method}

The experimental method used set only few demands on the criteria of purity of the chemicals. The most important is that these must not contain impurities that change their UV-Vis absorption spectra in the region of wavelengths where calculations are carried out during the change in acidity of medium. This can be easily checked by titrating solution containing pure acid or base with an acidic or basic titrant, respectively. Any irregular behavior on the set of spectra or deviation of isosbestic points proves the presence of unwanted impurities. Reversibility of proton change processes could be easily checked by back titration. The presence of unwanted side reactions could be also determined from UV-Vis spectra as usually these reactions captivate the compounds under study and thus cause change in their spectra.

The preparation of all solutions and measurements were carried out in a professional glovebox in argon atmosphere, where the contents of $\mathrm{O}_{2}$ and $\mathrm{H}_{2} \mathrm{O}$ were less than 1 ppm. Individual concentrations of bases in the mixtures were $(1.7-4.9) \times 10^{-5} \mathrm{M}$ and overall concentration of bases never exceeded $8.5 \times 10^{-5}$. Solutions of methanesulfonic acid and $\mathbf{3 2} \mathbf{b}$ or $\mathbf{3 9 b}$ were used as acidic and basic titrants, respectively. The UV-Vis spectra measurements were carried out in an external cell compartment, situated in the glovebox. The cell compartment was connected to the UV-Vis spectrophotometer by means of two quartz fiber optic cables. Titration experiments were carried out in standard $1 \mathrm{~cm}$ path length $4 \mathrm{ml}$ open-top screw cap quartz cuvette. First, the diluted standard solution of both bases was titrated separately with acid and base by means of gastight microliter syringes. So were obtained spectra of pure neutral and protonated forms and some spectra of mixture of neutral and protonated form. Backtitration with stronger base shows the reversibility of protonation process. The mixture of two bases was titrated in similar way and 5-30 spectra of were obtained.

\section{Calculation methods.}


General essence of calculation methods of pure UV-Vis spectrophotometric method is as follows. According to the Lambert-Beer law the net absorbance $A^{\lambda}$ of the solution containing two partially protonated (expressed in ion-paired form) neutral bases (that is four separate compounds) in a layer of unit thickness at wavelength $\lambda$ and using normalized concentrations as defined in eq-s 2 and 3 expresses as follows:

$$
\begin{gathered}
A^{\lambda}=\left[\mathrm{HB}_{1}^{+} \mathrm{A}^{-}\right] \varepsilon_{\mathrm{HB}_{1}^{+} \mathrm{A}^{-}}^{\lambda}+\left[\mathrm{B}_{1}\right] \varepsilon_{\mathrm{B}_{1}}^{\lambda}+\left[\mathrm{HB}_{2}^{+} \mathrm{A}^{-}\right] \varepsilon_{\mathrm{HB}_{2}^{+} \mathrm{A}^{-}}^{\lambda}+\left[\mathrm{B}_{2}\right] \varepsilon_{\mathrm{B}_{2}}^{\lambda} \\
{\left[\mathrm{HB}_{1}^{+} \mathrm{A}^{-}\right]=1-\left[\mathrm{B}_{1}\right]} \\
{\left[\mathrm{HB}_{2}^{+} \mathrm{A}^{-}\right]=1-\left[\mathrm{B}_{2}\right]}
\end{gathered}
$$

where $\varepsilon_{\mathrm{x}}{ }^{\lambda}$ are normalized absorbance coefficient at given wavelength. The eq 1 can be rearranged:

$$
A^{\lambda}=\varepsilon_{\mathrm{HB}_{1}^{+} \mathrm{A}^{-}}^{\lambda}+\varepsilon_{\mathrm{HB}_{2}^{+} \mathrm{A}^{-}}^{\lambda}+\left[\mathrm{B}_{1}\right]\left(\varepsilon_{\mathrm{B}_{1}}^{\lambda}-\varepsilon_{\mathrm{HB}_{1}^{+} \mathrm{A}^{-}}^{\lambda}\right)+\left[\mathrm{B}_{2}\right]\left(\varepsilon_{\mathrm{B}_{2}}^{\lambda}-\varepsilon_{\mathrm{HB}_{2}^{+} \mathrm{A}^{-}}^{\lambda}\right)
$$

If we take the normalized absorbance coefficients of pure protonated forms to the left side of the equation and divide both sides of the equation with $\left(\varepsilon_{\mathrm{B}_{2}}^{\lambda}-\varepsilon_{\mathrm{HB}_{2}^{+} \mathrm{A}^{-}}^{\lambda}\right)$, we get:

$$
\frac{A^{\lambda}-\varepsilon_{\mathrm{HB}_{1}^{+} \mathrm{A}^{-}}^{\lambda}-\varepsilon_{\mathrm{HB}_{2}^{+} \mathrm{A}^{-}}^{\lambda}}{\left(\varepsilon_{\mathrm{B}_{2}}^{\lambda}-\varepsilon_{\mathrm{HB}_{2}^{+} \mathrm{A}^{-}}^{\lambda}\right)}=\left[\mathrm{B}_{1}\right] \frac{\left(\varepsilon_{\mathrm{B}_{1}}^{\lambda}-\varepsilon_{\mathrm{HB}_{1}^{+} \mathrm{A}^{-}}^{\lambda}\right)}{\left(\varepsilon_{\mathrm{B}_{2}}^{\lambda}-\varepsilon_{\mathrm{HB}_{2}^{+} \mathrm{A}^{-}}^{\lambda}\right)}+\left[\mathrm{B}_{2}\right]
$$

This equation describes the line with a slope $\left[\mathrm{B}_{1}\right]$ and intercept $\left[\mathrm{B}_{2}\right]$. At given wavelength all the $\varepsilon^{\lambda}$-s are constant and are easy to determine from the spectra of solutions of pure acid and base forms of compounds. At different wavelengths of solution of certain acidity are all the members except concentrations in equation 5 variables and with regression analysis the latter ones are determinable. Using the normalized concentrations from eq-s 2 and 3 and $\Delta \mathrm{p} K_{\text {ip }}$ calculation equation 4 of Experimental Section of article we get:

$$
\Delta \mathrm{p} K_{\mathrm{ip}}=\log \frac{\left[\mathrm{B}_{1}\right]\left(1-\left[\mathrm{B}_{2}\right]\right)}{\left(1-\left[\mathrm{B}_{1}\right]\right)\left[\mathrm{B}_{2}\right]}
$$


The method is universal, but to employ it one needs spectra of pure acid and base forms of the compounds to determine corresponding $\varepsilon^{\lambda}$-s. Also one needs to know the ratio of concentrations of compounds in mixture and pure forms.

Sometimes, depending on spectra of compounds, it is possible to use very simple and elegant calculation methods to get indicator ratios. On the simpler cases one needs only the spectra of acid and base form of the mixtures and a set spectra of mixtures of variable acidity. Some examples of different cases are given here.

a) If there is a wavelength $\lambda$, at which neither forms of one compound do not absorb and basic form of second compound absorb

$$
\varepsilon_{\mathrm{HB}_{1}^{+} \mathrm{A}^{-}}^{\lambda}=\varepsilon_{\mathrm{HB}_{2}^{+} \mathrm{A}^{-}}^{\lambda}=\varepsilon_{\mathrm{B}_{2}}^{\lambda}=0 \quad \text { and } \quad \varepsilon_{\mathrm{B}_{1}}^{\lambda} \neq 0
$$

then the eq 4 simplifies:

$$
A^{\lambda}=\left[\mathrm{B}_{1}\right] \varepsilon_{\mathrm{B}_{1}}^{\lambda}
$$

and the indicator ratio of first compound expresses then:

$$
\frac{\left[\mathrm{B}_{1}\right]}{\left[\mathrm{HB}_{1}^{+} \mathrm{A}^{-}\right]}=\frac{A^{\lambda}}{A_{\mathrm{B}}^{\lambda}-A^{\lambda}}
$$

$A^{\lambda}$ is absorbance of solution where both compounds are in acid and base form and $A_{\mathrm{B}}^{\lambda}$ is absorbance of solution having both compounds in base form.

b) If one compound has an isosbestic point at certain wavelength that is both acid an base form have same absorbance coefficients and only basic form of second compound absorbs

$$
\varepsilon_{\mathrm{HB}_{2}^{+} \mathrm{A}^{-}}^{\lambda}=\varepsilon_{\mathrm{B}_{2}}^{\lambda} \neq 0 \neq \varepsilon_{\mathrm{B}_{1}}^{\lambda} \quad \text { and } \quad \varepsilon_{\mathrm{HB}_{1}^{+} \mathrm{A}^{-}}^{\lambda}=0
$$

then eq 4 simplifies:

$$
A^{\lambda}=\left[\mathrm{B}_{1}\right] \varepsilon_{\mathrm{B}_{1}}^{\lambda}+\varepsilon_{\mathrm{HB}_{2}^{+} \mathrm{A}^{-}}^{\lambda}
$$

The indicator ratio of second compound expresses then as follows: 


$$
\frac{\left[\mathrm{B}_{1}\right]}{\left[\mathrm{HB}_{1}^{+} \mathrm{A}^{-}\right]}=\frac{A^{\lambda}-A_{\mathrm{HB}^{+} \mathrm{A}^{-}}^{\lambda}}{A_{\mathrm{B}}^{\lambda}-A^{\lambda}}
$$

$A_{\mathrm{HB}^{+} \mathrm{A}^{-}}^{\lambda}$ is here a net absorbance of mixture solution where both compounds are in acid forms.

c) If there is a spectrum of the mixture where both compounds are in base form then the net absorbance from eq 1 we get:

$$
A^{\lambda}=\left[\mathrm{B}_{1}\right] \varepsilon_{\mathrm{B}_{1}}^{\lambda}+\left[\mathrm{B}_{2}\right] \varepsilon_{\mathrm{B}_{2}}^{\lambda}
$$

The rightsided members of this eq can be expressed as absorbances of pure compounds in base forms multiplied by coefficients $b_{n}$ :

$$
\left[\mathrm{B}_{1}\right]_{\text {mixture }} \varepsilon_{\mathrm{B}_{1}}^{\lambda}=\mathrm{b}_{1}^{\mathrm{B}} \quad A_{\mathrm{B}_{1} \text { pure }}^{\lambda}
$$

and

$$
\left[\mathrm{B}_{2}\right]_{\text {mixture }} \varepsilon_{\mathrm{B}_{2}}^{\lambda}=\mathrm{b}_{2}^{\mathrm{B}} A_{\mathrm{B}_{2} \text { pure }}^{\lambda}
$$

These coefficients $b_{n}^{B}$ are constant over the wavelength range, where $\varepsilon^{\lambda}$-s do not equal to zero. From the combination of eq-s 11,12 and 13 is possible to calculate from the spectrum of the mixture of compounds in base form, and from the spectra of both compounds in base form coefficients $b_{1}^{B}$ and $b_{2}^{B}$ using least squares minimization over a wavelength range by minimizing $S_{p}$ :

$$
\mathrm{S}_{\mathrm{p}}=\sum_{\lambda}\left[A^{\lambda}-\left(\mathrm{b}_{1}^{\mathrm{B}} A_{\mathrm{B}_{1} \text { pure }}^{\lambda}+\mathrm{b}_{2}^{\mathrm{B}} A_{\mathrm{B}_{2} \text { pure }}^{\lambda}\right)\right]^{2}
$$

These coefficients $b_{1}^{B}$ and $b_{2}^{B}$ show the ratio of concentrations in mixture and pure forms. Analogously the absorbance of the mixture solution where both compounds are in acid and base form by combining eq-s $4,12,13$, and introducing for both compounds a dissociation level $\alpha_{n}$, which shows the ratio of base form to analytical concentration we get: 


$$
A^{\lambda}=\mathrm{b}_{1}^{\mathrm{A}^{2}} A_{\mathrm{HB}_{1}^{+} \mathrm{A}_{\text {pure }}^{-}}^{\lambda}+\mathrm{b}_{2}^{\mathrm{A}^{\mathrm{z}}} A_{\mathrm{HB}_{2}^{+} \mathrm{A}_{\text {pure }}^{-}}^{\lambda}+\alpha_{1} \mathrm{~b}_{1}^{\mathrm{B}}\left(A_{\mathrm{B}_{1} \text { pure }}^{\lambda}-A_{\mathrm{HB}_{1}^{+} \mathrm{A}_{\text {pure }}^{-}}^{\lambda}\right)+\alpha_{2} \mathrm{~b}_{2}^{\mathrm{B}}\left(A_{\mathrm{B}_{2} \text { pure }}^{\lambda}-A_{\mathrm{HB}_{2}^{+} \mathrm{A}^{-} \text {pure }}^{\lambda}\right)
$$

from this eq using the least squares minimization over the wavelength range described in eq 14 by minimizing $S_{\mathrm{s}}$ respective $\alpha_{1}$ and $\alpha_{2}$ for compounds at different acidities are found

$$
\mathrm{S}_{\mathrm{s}}=\sum_{\lambda}\left\{A^{\lambda}-\mathrm{b}_{1}^{\mathrm{A}^{z}} A_{\mathrm{HB}_{1}^{+} \mathrm{A}_{\text {pure }}^{-}}^{\lambda}-\mathrm{b}_{2}^{\mathrm{A}^{2}} A_{\mathrm{HB}_{2}^{+} \mathrm{A}_{\text {pure }}^{-}}^{\lambda}-\left[\alpha_{1} \mathrm{~b}_{1}^{\mathrm{B}}\left(A_{\mathrm{B}_{1} \text { pure }}^{\lambda}-A_{\mathrm{HB}_{1}^{+} \mathrm{A}_{\text {pure }}^{-}}^{\lambda}\right)+\alpha_{2} \mathrm{~b}_{2}^{\mathrm{B}}\left(A_{\mathrm{B}_{2 \text { pure }}}^{\lambda}-A_{\mathrm{HB}_{2}^{+} \mathrm{A}_{\text {pure }}^{-}}^{\lambda}\right)\right]\right\}^{2}
$$

These $\alpha_{1}$ and $\alpha_{2}$ are substituted to $\Delta \mathrm{p} K_{\text {ip }}$ equation and the $\Delta \mathrm{p} K_{\text {ip }}$ expresses then:

$$
\Delta \mathrm{p} K_{\mathrm{ip}}=\log \frac{\alpha_{1}\left(1-\alpha_{2}\right)}{\left(1-\alpha_{1}\right) \alpha_{2}}
$$

This so called least-squares of linear combination method is universal and can be used when compounds have overlapping absorbances, the only limit is that, the spectra must not be identical. From UV-Vis spectrophotometric data it is possible to calculate with good confidence level $\Delta \mathrm{p} K_{\text {ip }}$ values up to 2.5 units. Usually the $\Delta \mathrm{p} K_{\text {ip }}$ values obtained using different data treatment methods agreed well. The raw spectrophotometric data was imported to and calculations were done in spreadsheet calculation program MS EXCEL.

The calculation method used for $\Delta \mathrm{p} K_{\mathrm{ip}}$ calculation of the base pairs in which one of them has poor

UV spectra is described in detail in ref 1.

The correction for ion-pairing was calculated as in refs $1,3,4$.

\section{References to Details of the UV-Vis Spectrophotometric Measurement Method}

1. Rodima, T.; Kaljurand, I.; Pihl, A.; Mäemets, V.; Leito, I.; Koppel, I. J. Org. Chem. 2002. 67, 1873 - 1881 .

2. Kaljurand, I.; Rodima, T.; Pihl, A.; Mäemets, V.; Leito, I.; Koppel, I. A.; Mishima, M. J. Org. Chem. 2003, 68, 9988-9993.

3. Abdur-Rashid, K.; Fong, T. P.; Greaves, B.; Gusev, D. G.; Hinman, J. G.; Landau, S. E.; Lough, A. J.; Morris, R. H. J. Am. Chem. Soc. 2000, 122, 9155-9171.

4. Fuoss, R. M. J. Am. Chem. Soc. 1958, 80, 5059-5061. 


\section{Crystal Structure Analyses}

8c. All three guanidine centers $\mathrm{C}(1), \mathrm{C}(6)$ and $\mathrm{C}(11)$ are almost trigonal planar $\left(\sum \leq 360^{\circ}\right)$. The guanidine double bond lengths of 8c (N4-C6 128.7(2) pm, N7-C11 129.4(2) pm, N1-C1 128.3(2) pm)

are slightly longer than the "normal" $\mathrm{C}-\mathrm{N}$ double bonds $(127.9 \mathrm{pm}) .{ }^{1}$ On the other hand these C-N distances are shorter than the value found for $\mathrm{Ph}_{2}$ PTMG (129.3(4) pm). ${ }^{2}$ Meanwhile, there is a distinct difference in bond lengths between guanidine $\mathrm{C}-\mathrm{N}$ double bonds on one hand and the distances of carbon atoms of the guanidine imino group, $\mathrm{C}(1), \mathrm{C}(6)$ and $\mathrm{C}(11)$ carbons, to the nitrogen atoms $\mathrm{N}(2)$, $\mathrm{N}(3), \mathrm{N}(5), \mathrm{N}(6), \mathrm{N}(8)$ and $\mathrm{N}(9)$ on the periphery (average $138.3 \mathrm{pm}$ ) on the other hand. The phosphorus atom in the 8c with the angles N10-P1-N4: $107.16(7)^{\circ}, \mathrm{N} 4-\mathrm{P} 1-\mathrm{N} 7: 105.24(7)^{\circ}, \mathrm{N} 14-\mathrm{P} 1-$ N1: $108.89(7)^{\circ}$, N7-P1-N1: 103.33 (7) ${ }^{\circ}$ being smaller and N10-P1-N7: $117.36(7)^{\circ}$, N10-P1-N1: $114.32(7)^{\circ}$ angles larger than the ideal tetrahedral angle, slightly deviates from the tetrahedral coordination. The P-N bonds lengths to tmg groups of $\mathbf{8 c}$ are slightly longer than the value for TMG substituted phosphorus (III) compounds (for $\mathrm{Ph}_{2} \mathrm{P}(\operatorname{tmg})$ 169.6(3) pm was found ${ }^{2}$ ). The average P-N-C-N torsion angle $\left(30.2^{\circ}\right)$ for the evaluation of planarity at the $\mathrm{C}-\mathrm{N}$ double bond indicate on a deviation of the C-N double bond from the expected planar geometry. In agreement with this trend are the angles P1-N1-C1, 134.5 (14), P1-N7-C11, 127.8 (13) and P1-N10-C16, 129.13 (13) (average P-N-C angle of $\left.130.5^{\circ}\right)$, which are greater than the expected angle for $\mathrm{sp}^{2}$-hybridised nitrogen. 


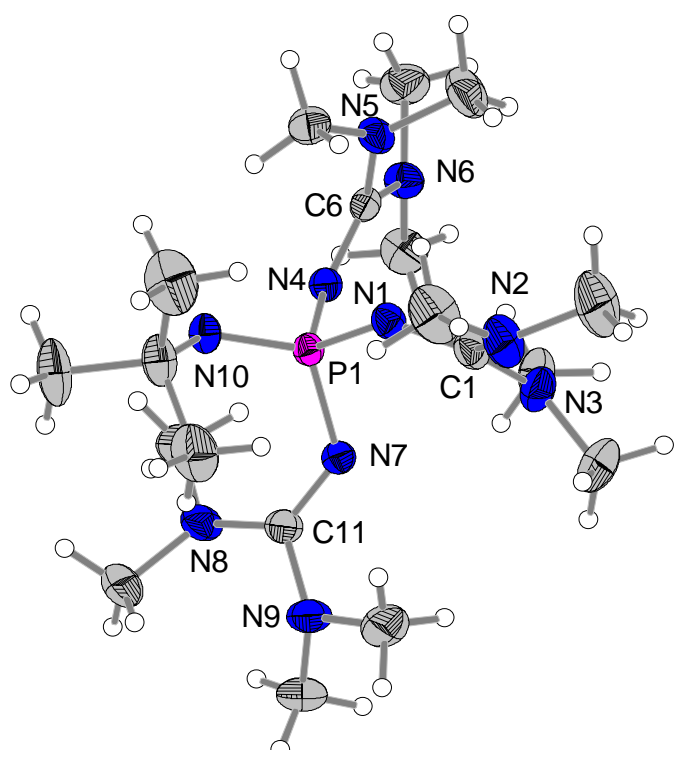

Figure $\mathrm{S} 1$. Molecular structure of $\left[(\mathrm{dma})_{2} \mathrm{C}=\mathrm{N}\right]_{3} \mathrm{P}=\mathrm{N}-t-\mathrm{Bu}(\mathbf{8 c})$ with $50 \%$ thermal ellipsoids.

$\mathbf{8 c} \cdot \mathrm{HBF}_{4} \cdot$ This salt crystallizes with two anion-cation pairs $\left(\mathrm{A} \cdot \mathrm{BF}_{4}\right.$ and $\left.\mathrm{B} \cdot \mathrm{BF}_{4}\right)$ in the asymmetric unit. The difference between the cations is negligible. Therefore only the pair $\mathrm{A} \cdot \mathrm{BF}_{4}$ is discussed. The position of the proton was taken from the difference-fourier-map and refined isotropically. Its location on the former phosphimino nitrogen is in accordance with the observation of ${ }^{2} J_{\mathrm{PH}}$ constant in ${ }^{1} \mathrm{H}$ and ${ }^{31} \mathrm{P}$ NMR spectra. For the phosphazenium cation of $\mathrm{A} \cdot \mathrm{BF}_{4}$ only a slight deviation from tetrahedral arrangement of phosphorus atom was revealed. The angles N1-P1-N7 107.89(12) ${ }^{\circ}$ and N4-P1-N10 $105.01(12)^{\circ}$ are slightly smaller and the angles N1-P1-N10 109.20(12 ${ }^{\circ}$, N4-P1-N7 $110.40(12)^{\circ}$, N7P1-N10 110.82(12) N1-P1-N4 113.52(12) ${ }^{\circ}$, are larger than the ideal tetrahedral angle.

All three guanidine centers $\mathrm{C}(1), \mathrm{C}(6)$ and $\mathrm{C}(11)$ are almost ideally trigonal planar: The sums of the $\mathrm{N}-\mathrm{C}-\mathrm{N}$ angles are $359.9^{\circ}, 360.0^{\circ}$ and $360.0^{\circ}$, respectively. Also, the dimethylamino nitrogen atoms are in nearly planar configurations. The average (of 6 values) of sums of the C-N-C angles is $357.8^{\circ}$. This is larger than the same characteristic in the neutral base $355.1^{\circ}$. Since these sums of angles are rather insensitive to out-of-planarity distortions in close-to-planar configurations, this difference of $2.7^{\circ}$ is 
significant. As was previously observed for peralkylated polyguanidines and 1,8bis(tetramethylguanidino)naphthalene and their protonated forms the dimethylamino groups in the periphery of $\mathrm{A} \cdot \mathrm{BF}_{4}$ as a result of steric repulsion deviate from the ideal (coplanar with the guanidine core) geometry. The average angle between the guanidine moieties and the dimethylamino groups (calculated as the average of two N-C-N-C torsional angles) is $26.9^{\circ}$.

On protonation of the free base 8c the bond lengths of imino groups between C1, C6, C11 and N1, N4, N7, respectively, become elongated. The guanidine double bonds lengths $(136.0 \pm 0.1 \mathrm{pm})$ of $\mathrm{A} \cdot \mathrm{BF}_{4}$ are shorter than the "normal" $\mathrm{C}-\mathrm{N}$ single bond $(141.6 \mathrm{pm})^{2}$, meanwhile these bonds are longer than the "normal" C-N double bond $(127.9 \mathrm{pm})^{2}$. On the other hand the average $\mathrm{C}-\mathrm{N}$ guanidine double bond lengths $(136 \pm 10 \mathrm{pm})$ are very similar to the average bond length $(136.5 \mathrm{pm})$ between the $\mathrm{C} 1$, C6 and $\mathrm{C} 11$ carbons and the nitrogens of the $\mathrm{NMe}_{2}$ groups. These observations imply significant delocalization of positive charge in the $\mathrm{A} \cdot \mathrm{BF}_{4}$ over the three $\mathrm{TMG}$ groups due to conjugation of guanidino moieties with the phosphonium center. The P-N bonds to guanidine groups reveal partial double bond character. The P-N bonds to guanidine groups [P1-N1 163,3(2), P1-N4 162,0(2), P1-N7 161,9(2) pm, average $162.4 \mathrm{pm}]$ reveal partial double bond character.

The P-N-C angles in A.BF 4 , C1-N1-P1, 130.0(2) ${ }^{\circ}$, C6-N4-P1, 130.81(19) and C11-N7-P1, 131.7(2), apparently, due to conjugation of the tmg units with positively charged phosphorus atom, are significantly larger than the expected to be $120^{\circ}$ for $\mathrm{sp}^{2}$-hybridised nitrogen.

The average $\mathrm{P}-\mathrm{N}-\mathrm{C}-\mathrm{N}$ torsion angle $\left(36.4^{\circ}\right)$ indicating on the deviation from the planar arrangement of at the $\mathrm{C}=\mathrm{N}$ bond was found to be larger than the respective value in $\mathbf{8 c}\left(30.2^{\circ}\right)$, but on the other hand is much smaller than the respective average value found for the $(\operatorname{tmg})_{3} \mathrm{PH}^{+}$cation $\left(\text {average } 43.8^{\circ}\right)^{1 \mathrm{~b}}$. 


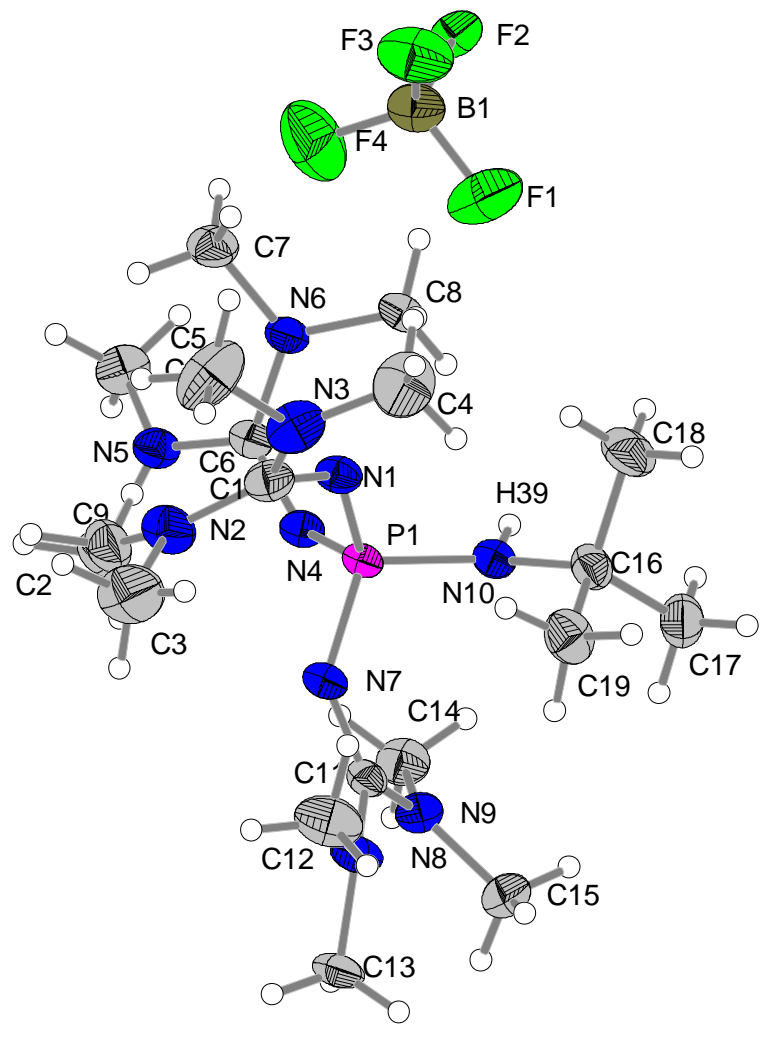

Figure S2. Molecular structure of $\left[(\mathrm{dma})_{2} \mathrm{C}=\mathrm{N}\right]_{3} \mathrm{P}=\mathrm{N}-t-\mathrm{Bu} \cdot \mathrm{HBF}_{4}\left(\mathbf{8 c} \cdot \mathbf{H B F}_{4}\right)$ with $50 \%$ thermal ellipsoids.

\section{References for Crystal Structure Analyses}

1. Münchenberg, J.; Thönnessen, H.; Jones, P. G.; Schmutzler, R. Phosphorus, Sulphur, and Silicon $1997,123,57-74$.

2. Münchenberg, J.; Böge, O; Fischer, A. K; Thönnessen, H.; Jones, P. G.; Schmutzler, R. Phosphorus, Sulphur, and Silicon 1994, 86, 103-111. 


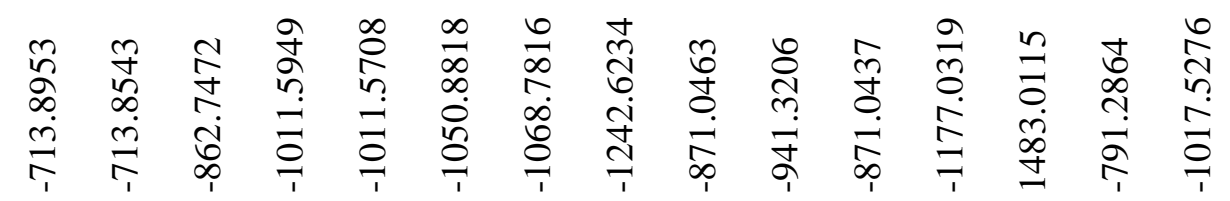

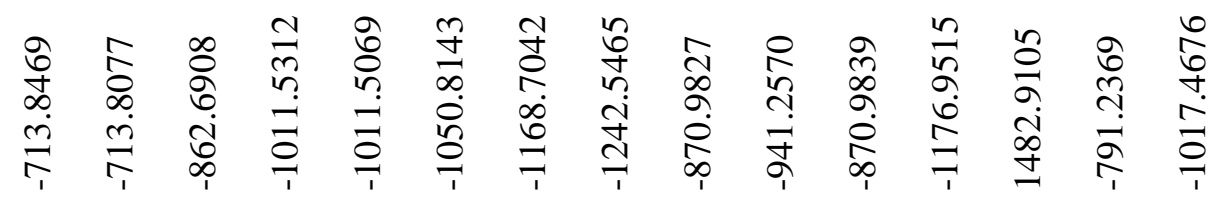

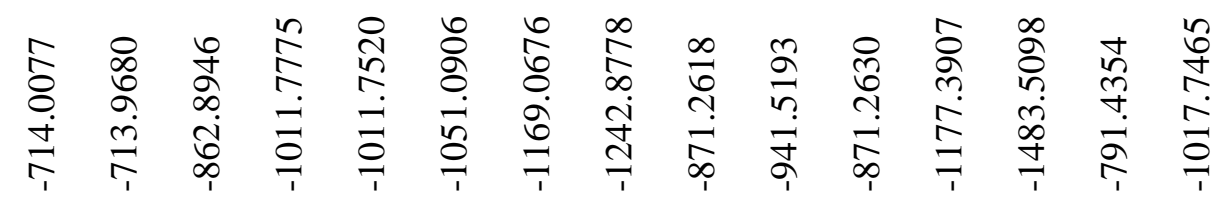

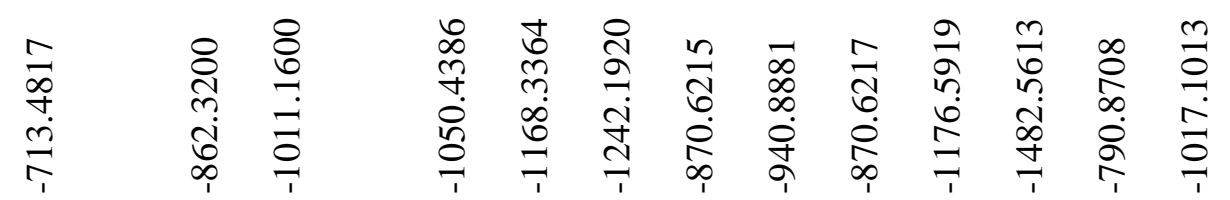

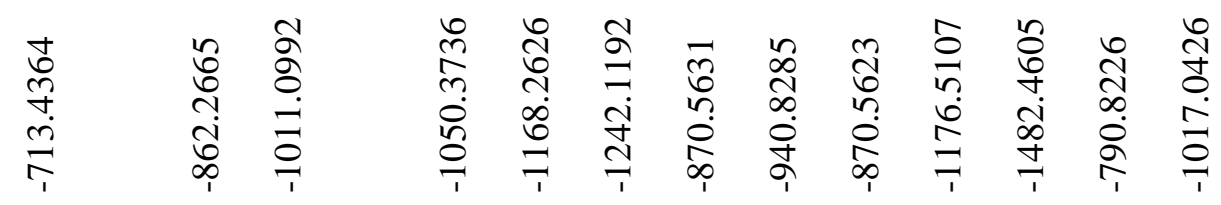

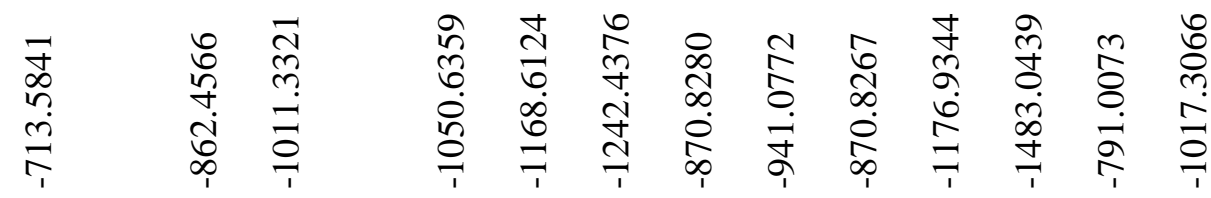

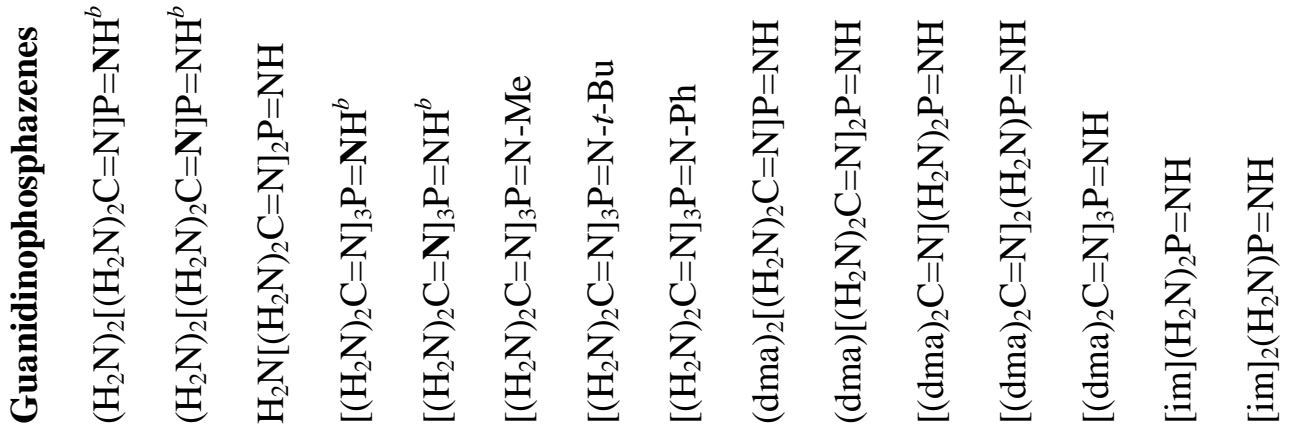




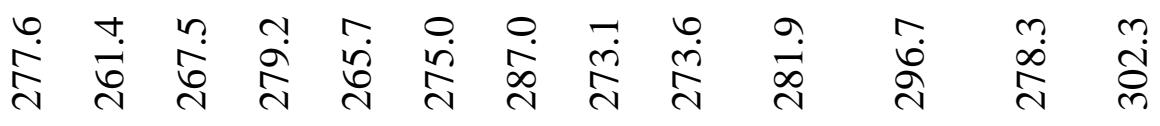

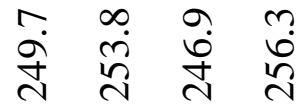

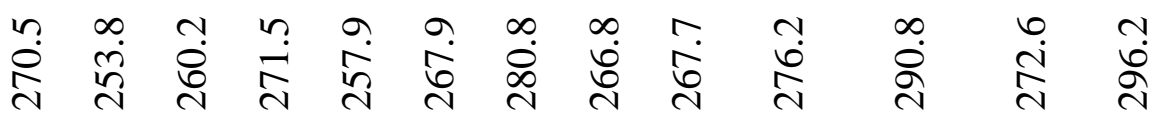

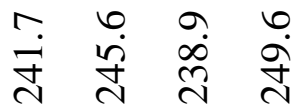

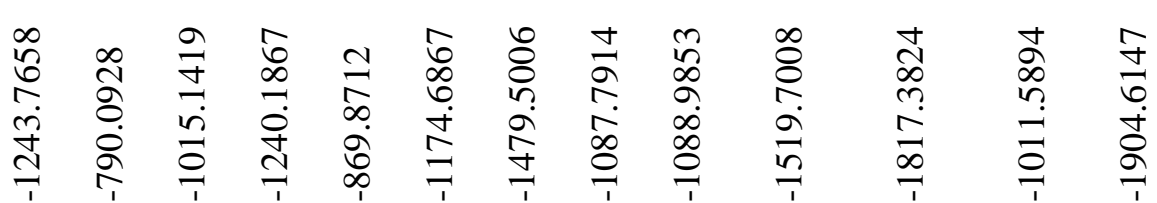

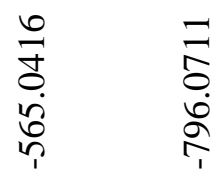

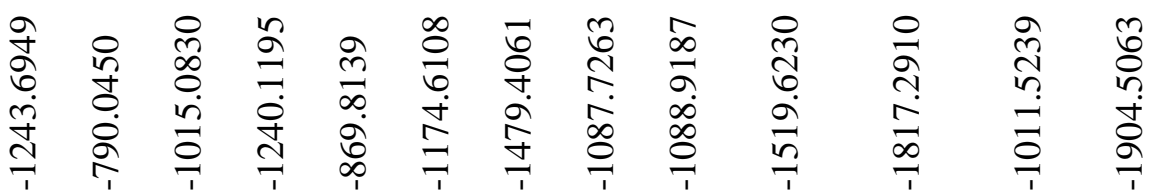

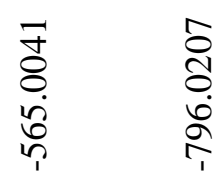

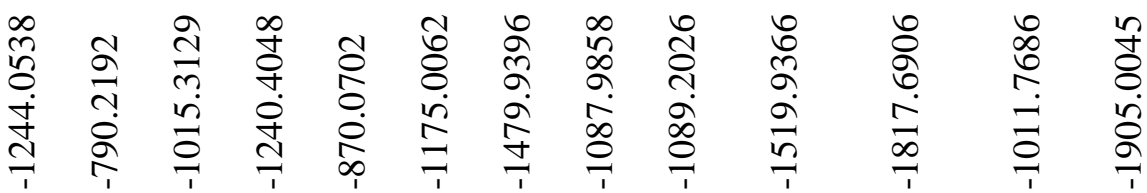

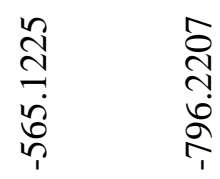

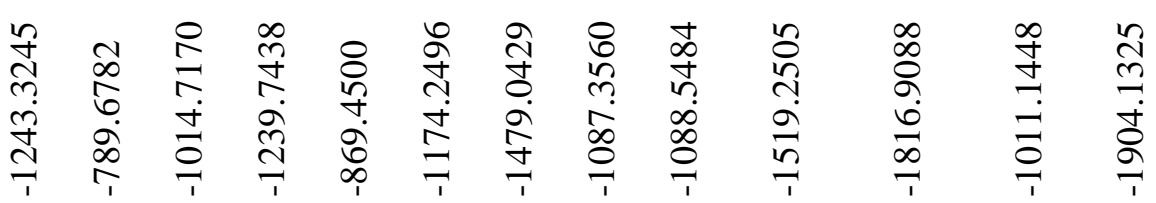

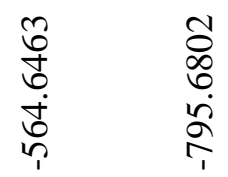

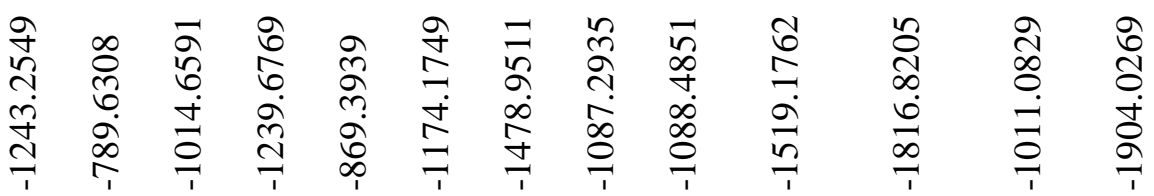

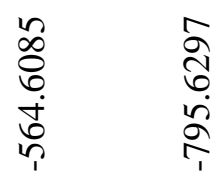

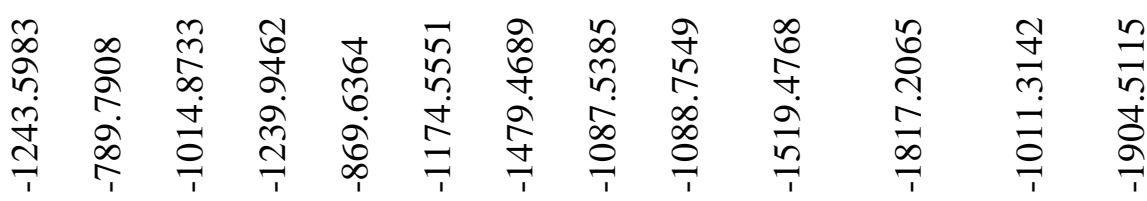

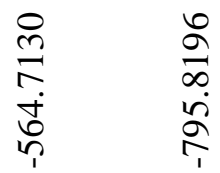

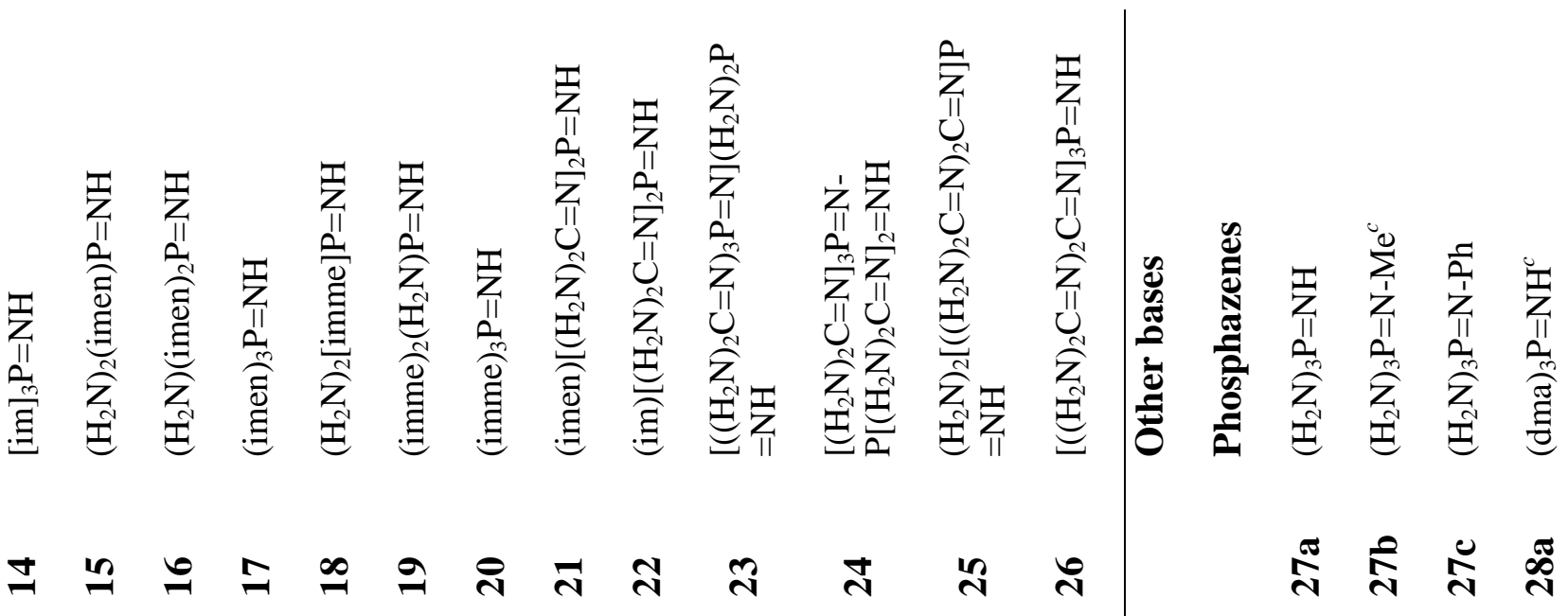




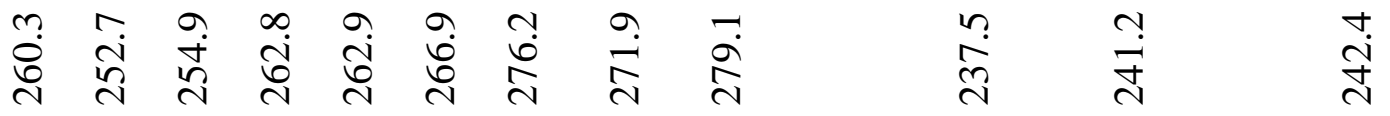

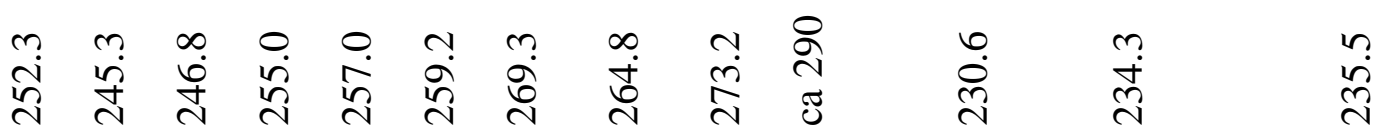

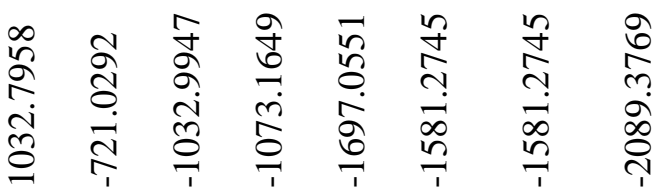

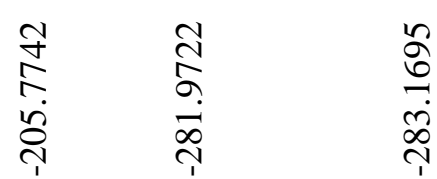

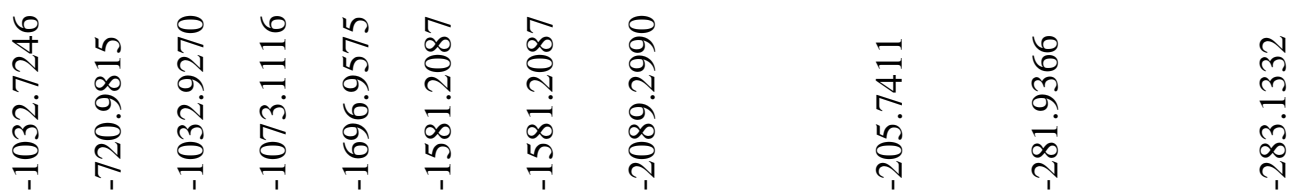

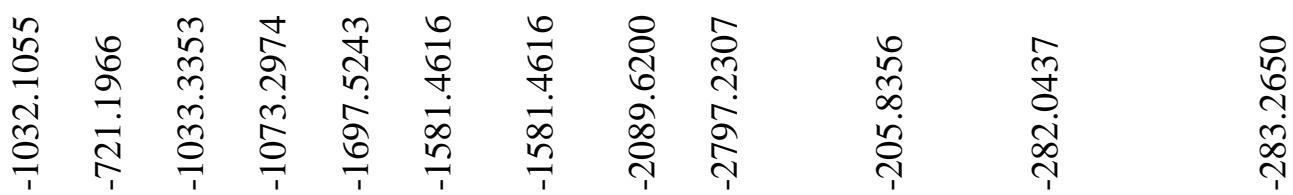

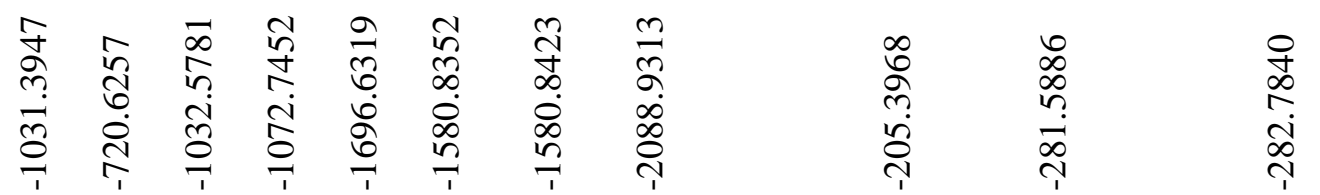

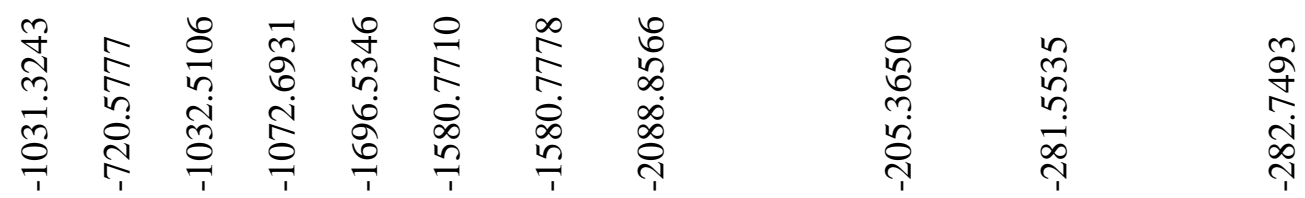

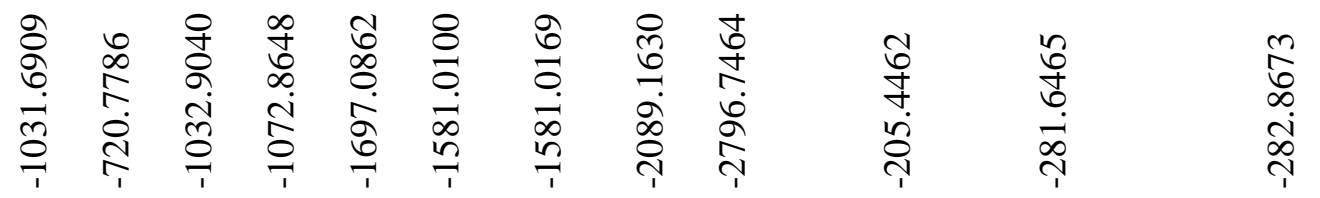

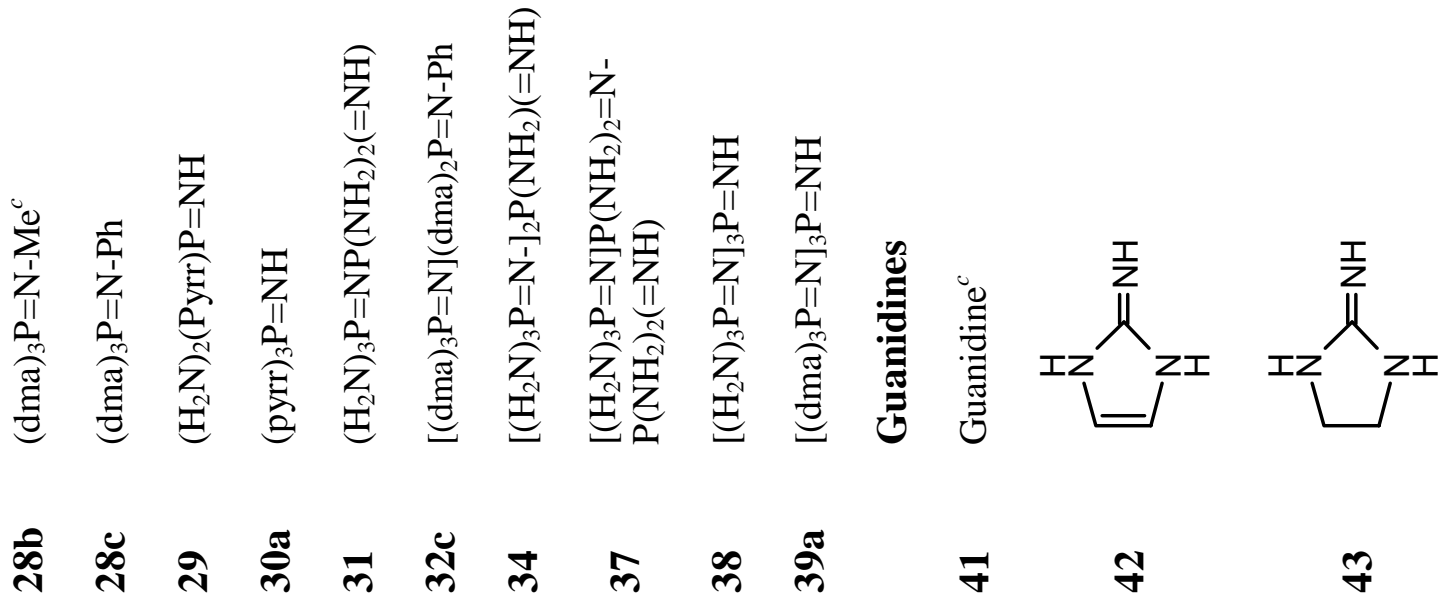




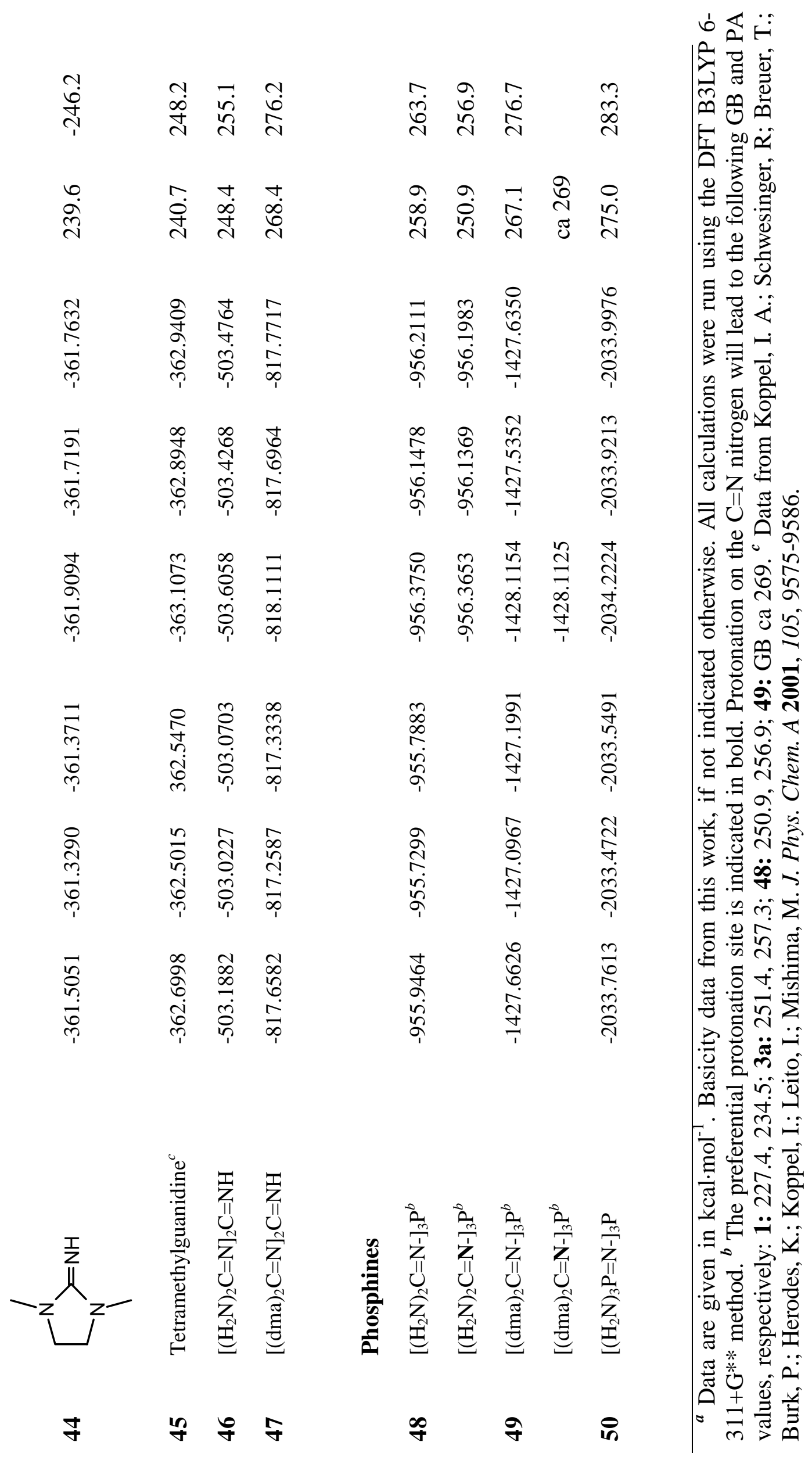




\section{References (full citations)}

7. (c) Schwesinger, R.; Schlemper, H.; Hasenfratz, C.; Willaredt, J.; Dambacher, T.; Breuer, T.;

Ottaway, C.; Fletschinger, M.; Boele, J.; Fritz, H.; Putzas, D.; Rotter, H. W.; Bordwell, F. G.; Satish, A. V.; Ji G.-Z.; Peters, E.-M.; Peters, K.; von Schnering, H. G.; Walz, L. Liebigs Ann. 1996, 1055-1081.

21. Gaussian 03, Revision C.02, Frisch, M. J.; Trucks, G. W.; Schlegel, H. B.; Scuseria, G. E.; Robb, M. A.; Cheeseman, J. R.; Montgomery, Jr., J. A.; Vreven, T.; Kudin, K. N.; Burant, J. C.; Millam, J. M.; Iyengar, S. S.; Tomasi, J.; Barone, V.; Mennucci, B.; Cossi, M.; Scalmani, G.; Rega, N.; Petersson, G. A.; Nakatsuji, H.; Hada, M.; Ehara, M.; Toyota, K.; Fukuda, R.; Hasegawa, J.; Ishida, M.; Nakajima, T.; Honda, Y.; Kitao, O.; Nakai, H.; Klene, M.; Li, X.; Knox, J. E.; Hratchian, H. P.; Cross, J. B.; Bakken, V.; Adamo, C.; Jaramillo, J.; Gomperts, R.; Stratmann, R. E.; Yazyev, O.; Austin, A. J.; Cammi, R.; Pomelli, C.; Ochterski, J. W.; Ayala, P. Y.; Morokuma, K.; Voth, G. A.; Salvador, P.; Dannenberg, J. J.; Zakrzewski, V. G.; Dapprich, S.; Daniels, A. D.; Strain, M. C.; Farkas, O.; Malick, D. K.; Rabuck, A. D.; Raghavachari, K.; Foresman, J. B.; Ortiz, J. V.; Cui, Q.; Baboul, A. G.; Clifford, S.; Cioslowski, J.; Stefanov, B. B.; Liu, G.; Liashenko, A.; Piskorz, P.; Komaromi, I.; Martin, R. L.; Fox, D. J.; Keith, T.; Al-Laham, M. A.; Peng, C. Y.; Nanayakkara, A.; Challacombe, M.; Gill, P. M. W.; Johnson, B.; Chen, W.; Wong, M. W.; Gonzalez, C.; and Pople, J. A.; Gaussian, Inc., Wallingford CT, 2004. 


\section{Optimized Geometries Obtained from the}

\section{Computations}

1

Brutoformula: C1H9N6P1

0,1

$\mathrm{N},-0.8239272775,-0.9195084199,-2.0588348835$

$\mathrm{P},-0.6728052502,0.1864707615,-0.9584227351$

$\mathrm{N}, 0.7707558725,0.3934625459,-0.1404453013$

$\mathrm{N},-1.911777504,-0.2007406484,0.1622064468$

$\mathrm{N},-0.9489790904,1.8238876117,-1.3452665421$

$\mathrm{H},-2.4030372552,0.610079299,0.51988857$

$\mathrm{H},-2.5609603161,-0.8584801574,-0.2565470631$

$\mathrm{H},-1.4740246379,1.9589078782,-2.2003843448$

$H,-0.1140580515,2.3948664863,-1.3253019089$

$\mathrm{H},-0.0731916553,-0.9752705743,-2.7375955441$

C, $1.181458505,-0.2853948039,0.8829214355$

$\mathrm{N}, 0.406964173,-1.0215066739,1.7377483427$

$\mathrm{N}, 2.5268029914,-0.2753105697,1.193579353$

$\mathrm{H}, 3.064675983,0.3750846187,0.6411071071$

$H, 2.7803123289,-0.3188730699,2.1697140739$

$\mathrm{H}, 0.828523013,-1.7963637368,2.2246264586$

$\mathrm{H},-0.5767318298,-1.0913105472,1.4910065343$

$\mathrm{HF}=-713.5840785 \mathrm{NImag}=0$

$1 \mathrm{H}+$

Brutoformula: C1H10N6P1(1+)

1,1

$N, 0.0958265325,-1.2161442643,-1.6693676177$ $\mathrm{P}, 0.1059680288,-1.1045617947,-0.0134066855$

$\mathrm{N}, 1.65162115,-1.5500481131,0.3716830533$

$\mathrm{H},-0.4648581373,2.2012592995,2.2350469511$

$\mathrm{N},-0.1315526172,0.2802926139,0.7482272239$

$\mathrm{N},-1.1673526642,-2.0670667049,0.4213874246$

$\mathrm{H},-0.7273790512,-1.5293683287,-2.1634123781$

$H, 0.9580189567,-1.2110409334,-2.1952143016$

$\mathrm{H}, 2.0355037839,-1.1963598661,1.237908893$

$\mathrm{H}, 2.0022995437,-2.4626740011,0.1107290791$

C, $-0.3862894786,1.5028244287,0.3330138162$

$\mathrm{N},-0.4991235502,1.8698473815,-0.9626778918$

$\mathrm{N},-0.5474136118,2.4601430592,1.265352505$

$\mathrm{H},-0.6941623232,2.8200834584,-1.2337916779$

$\mathrm{H},-0.3796408185,1.1837697764,-1.6906028192$

$\mathrm{H},-0.7371828123,3.4219345896,1.0361203899$

$\mathrm{H},-1.6221833085,-1.8670162714,1.3022379244$

$H,-1.1809077137,-3.0464271195,0.1671562402$

$H F=-714.0076764 \quad N I m a g=0$

$1 \mathrm{H}+$, protonated on $\mathrm{C}=\mathrm{N}$
Brutoformula: C1H10N6P1(1+)

1,1

N,-0.187259784,-1.1415684673,-1.5431487298

P, $-0.12644868837,-1.3663100042,0.1288332689$

$\mathrm{N}, 1.5270001407,-1.3824671111,0.425342889$

$\mathrm{N},-1.1847666011,-2.3689620217,0.5938428805$

$\mathrm{N},-0.4884503843,0.2745791306,0.7435393315$

$\mathrm{H},-1.2385436602,-2.7856961237,1.5118906173$

$\mathrm{H},-1.0392988331,-1.5236084277,-1.9462116914$

$\mathrm{H}, 0.6217952524,-1.51679576,-2.0288901977$

$\mathrm{H}, 1.842743789,-0.9543790424,1.2867231418$

$\mathrm{H}, 1.9874298453,-2.2748557865,0.2773572336$

C,- $0.2056685546,1.5052997932,0.2605178056$

$\mathrm{N}, 0.2858860998,1.6469646572,-0.9628377193$

$\mathrm{N},-0.43535888183,2.5783995621,1.0296609893$

$\mathrm{H}, 0.6284757006,2.5339923843,-1.2974498622$

$\mathrm{H}, 0.2465976561,0.8376306787,-1.5842692914$

$\mathrm{H},-0.64689439993,2.4823126322,2.0106138913$

$\mathrm{H},-0.4144173668,3.5126305634,0.6496315727$

$\mathrm{H},-1.1533464785,0.2493166661,1.5078953383$

$H F=-713.9680102 \quad N I m a g=0$

\section{2}

Brutoformula: $\mathrm{C} 2 \mathrm{H} 11 \mathrm{~N} 8 \mathrm{P} 1$

0,1

$\mathrm{N}, 0.7061091223,0.8120253943,-1.1289697415$

P. $0.4937157743,0.456487375,0.488650042$

$\mathrm{N}, 1.8441856157,-0.5770358013,0.8724690829$

$\mathrm{N},-0.723227216,-0.6635475649,0.6651988646$

$\mathrm{N}, 0.2668731185,1.7350033304,1.3902128611$

$\mathrm{H}, 0.7626140767,2.5704452226,1.102051648$

C, $1.0698810529,-0.0048918073,-2.0688364218$

C, $-1.8511555021,-0.4415567711,1.2765316534$

$\mathrm{H}, 2.6992251475,-0.0362819765,0.9754306933$

H,1.6754319403,-1.06457584477,1.7479151171

$\mathrm{N}, 1.6743160405,-1.2209698163,-1.9187314618$ $\mathrm{N}, 0.8555252406,0.3699450718,-3.3811638464$ $\mathrm{N},-2.2611652724,0.7347412936,1.8206553299$

$\mathrm{N},-2.7342428326,-1.5005588675,1.4037232517$ $\mathrm{H}, 1.5364139885,0.0785755162,-4.0672462145$ $H, 0.5317885895,1.3210874274,-3.4750757418$ $H, 1.8090416395,-1.5285052705,-0.9583728167$ $H, 1.5503655531,-1.916963609,-2.6363532593$

$\mathrm{H},-2.4945547084,-2.2895817966,0.8221200263$ H, $-3.7182167267,-1.27534909,1.4210677169$ H,-2.9581158508,0.7026651561,2.5482388309 $\mathrm{H},-1.510700285,1.4426438309,1.8805415968$

State $=1-A \quad N I m a g=0$

$2 \mathrm{H}+$

Brutoformula: C2H12N8P1(1+) 1,1

$N, 1.2149215209,0.8264590823,-0.8483360511$ $\mathrm{P}, 0.6604891906,0.4868122399,0.6322780724$ $\mathrm{N}, 1.7984927842,-0.0288586986,1.7314152222$ 
$\mathrm{N},-0.4615713449,-0.6936165186,0.6858479861$ $\mathrm{H},-3.4023364858,0.4703874022,1.5242317511$ $\mathrm{N}, 0.1373597956,1.9861552588,1.1822270413$ C, $1.3371320791,0.0159176308,-1.8821865222$ C, $-1.7470287792,-0.6373634171,0.9769743998$ $\mathrm{H}, 2.7172046386,0.3961146308,1.7085287072$ $\mathrm{H}, 1.8176253717,-1.0178633883,1.9401686477$ $\mathrm{N}, 0.8795685051,-1.2559156453,-1.9249950692$ $\mathrm{N}, 1.9768469702,0.4866277763,-2.9720444336$ $\mathrm{N},-2.431818903,0.4905261689,1.2569080506$ $\mathrm{N},-2.4428082771,-1.7974910073,0.9677825825$ $\mathrm{H}, 2.3385095017,1.4257060214,-2.9403109851$ $\mathrm{H}, 2.0568780174,-0.0355869304,-3.828681497$ $\mathrm{H}, 0.9424626397,-1.8122676383,-2.7623846543$ $H, 0.2820625807,-1.5740068235,-1.1720240056$ $\mathrm{H},-1.9293879617,-2.65877106655,0.8811807297$ H,-3.4113990923,-1.8465047002,1.2380875275 $\mathrm{H},-1.9327708497,1.3707609996,1.2806367917$ $H, 0.3223167521,2.7538596052,0.5473829032$ $\mathrm{H}, 0.3684926791,2.2131245112,2.1422608902$

$H F=-862.894581 \quad N I m a g=0$

\section{$3 a$}

\section{Brutoformula: C3H13N10P1}

0,1

$\mathrm{N}, 0.5150377961,-0.4532787429,-1.1739946118$ $\mathrm{P},-0.0007927528,-0.3373422817,0.437515029$ $\mathrm{N}, 1.3134362237,0.143566118,1.3410878782$ $\mathrm{N},-0.6802442077,-1.6692782287,1.0183937386$ $\mathrm{N},-1.0319866426,0.9744662635,0.3655665255$ $\mathrm{H},-0.1131651503,-2.121064482,1.7280174012$ C, $0.2461005112,-1.456351113,-1.9515702504$ C, $-2.240399451,0.9997637744,0.833291086$ C, $2.2423628061,0.9678437429,0.9787119906$ $\mathrm{N},-0.5973072113,-2.4947239178,-1.6702582441$ $\mathrm{N}, 0.8478841345,-1.5129661546,-3.2008244869$ $\mathrm{N},-3.0131569088,2.1265172554,0.591403739$ $\mathrm{N},-2.8625272761,0.0204236895,1.55697109$ $\mathrm{N}, 3.0782110736,1.4935979004,1.9488875563$ $\mathrm{N}, 2.5211169285,1.3874241324,-0.2936138485$ $H, 1.2885690116,-0.6471226004,-3.4728229752$ $\mathrm{H}, 0.3096637994,-1.9466712828,-3.9372148996$ $H,-0.4332034433,-3.3621628642,-2.1589593238$ $H,-0.8385996677,-2.5556114515,-0.667437169$ $H, 1.8865595289,1.0414403275,-1.0110257913$ $H, 2.9268682698,2.3020320791,-0.4136896969$ $\mathrm{H}, 4.0438822106,1.6372701386,1.6905568705$ $\mathrm{H}, 2.9431463882,1.072370034,2.8560174432$ H, $-3.8684682279,-0.0256277715,1.5000449517$ $\mathrm{H},-2.3395886822,-0.8672491798,1.5672566522$ $\mathrm{H},-2.4755486651,2.8970045547,0.2221069818$ $H,-3.6678503955,2.3857300597,1.3155823608$

$$
H F=-1011.3323143 \quad \mathrm{NImag}=0
$$

\section{$3 \mathrm{aH}+$}

Brutoformula: C3H14N10P1(1+)

1,1

$N, 0.2120454113,-0.2551931218,1.6759071497$

P, $-0.0599110184,-0.5529516319,0.1091686312$

$\mathrm{N},-1.5483480176,-0.0557877094,-0.3666606387$ $\mathrm{H}, 3.9138531107,-1.394246628,-0.2337766369$ $\mathrm{N}, 1.0720328973,0.090665136,-0.8939996572$ $\mathrm{N}, 0.1160354969,-2.2380465949,0.0397806102$ C, $-0.4382523118,0.5091804526,2.5230926039$ C, $2.3648977302,-0.1907261728,-0.8843501273$ C,- $-1.9521995902,0.3621359145,-1.5492293827$ $\mathrm{N}, 0.1533571034,0.7753162088,3.7144518476$ $\mathrm{N},-1.6615698222,1.0436469394,2.3116777678$ $\mathrm{N}, 2.9166213225,-1.2783840223,-0.3091107827$ $N, 3.2001775052,0.6636660199,-1.5178319615$ $\mathrm{N},-1.1435322942,0.5910478537,-2.6069248307$ $\mathrm{N},-3.2795822163,0.5889844629,-1.7171834754$ $\mathrm{H},-2.0896162383,0.8806652243,1.4070551304$ $\mathrm{H},-2.0441520711,1.7423550972,2.9272447369$ $H, 1.0205544736,0.3013684064,3.9084422101$ $\mathrm{H},-0.3742731398,1.1278314574,4.4966453712$ $\mathrm{H},-3.9053665797,0.2397059301,-1.0099401404$ H, $-3.6694552653,0.8115490141,-2.6185397275$ $\mathrm{H},-1.4954223513,1.0233444543,-3.4460216003$ $\mathrm{H},-0.1444747612,0.6142015345,-2.4144003437$ $\mathrm{H}, 2.8195471277,1.5202409179,-1.8830474386$ $\mathrm{H}, 4.1688327742,0.4514969855,-1.690162244$ $\mathrm{H}, 2.3041120318,-1.9780406824,0.0920096252$ $\mathrm{H},-0.1084399049,-2.6579141005,-0.8568344904$ $\mathrm{H},-0.3474714026,-2.7361114332,0.7925377959$

$H F=-1011.7768415 \quad$ NImag $=0$

\section{$3 \mathrm{aH}+$ protonated on $\mathrm{C}=\mathrm{N}$}

Brutoformula: C3H14N10P1(1+) 1,1 N, $-0.9674950245,0.9760872066,0.3122814021$ $\mathrm{P},-0.0102600713,-0.0900683463,-0.5156799229$ $\mathrm{N}, 1.309225565,-0.279806041,0.6710830165$ $\mathrm{N}, 0.7565954675,0.4135123028,-1.8133841898$ $\mathrm{N},-0.7151790217,-1.5458083077,-0.5988850015$ $\mathrm{H}, 0.3853724667,0.0371167676,-2.6800076526$ C, $-0.9748626328,2.284307937,0.1016584092$ $\mathrm{H},-0.3517902215,3.9010278613,-1.0084795893$ C,- $-1.8773836782,-1.970194748,-0.1555760691$ $\mathrm{N},-1.8146148787,3.0376682357,0.8542461122$ $\mathrm{N},-0.2093037611,2.9249882124,-0.8043074524$ $\mathrm{N},-2.2667016461,-3.2162247385,-0.5165893879$ $\mathrm{N},-2.7111493138,-1.271030613,0.65168024$ $H, 0.316184318,2.3407340761,-1.4603598165$ $\mathrm{H},-2.2957657255,2.5942595708,1.6182901655$ $\mathrm{H},-2.4719270127,-0.2932974138,0.7981908754$ H,-3.6689955487,-1.5607941796,0.7703417805 H,-1.6194726958,-3.7667481214,-1.0567146213 $\mathrm{H},-3.0547154903,-3.6773598964,-0.092963163$ $\mathrm{H},-1.8069244711,4.0435732037,0.8181233449$ C,2.6159577411, $-0.5236727998,0.4508865127$ $H, 1.0134450539,-0.269088788,1.6382929768$ 
N,3.1274906328,-0.3529763506,-0.7567100905 $\mathrm{N}, 3.3937830084,-0.9074892327,1.4828367248$ $\mathrm{H}, 2.9939540761,-1.1844630721,2.364199276$ $\mathrm{H}, 4.3940326347,-0.9730303317,1.3841548806$ $H, 4.0607002191,-0.6598152901,-0.9791194249$ $\mathrm{H}, 2.4498000103,-0.0114071055,-1.4774893364$

$H F=-1011.7520308 \quad \mathrm{NImag}=0$

\section{$3 b$}

Brutoformula: $\mathrm{C} 15 \mathrm{H} 37 \mathrm{~N} 10 \mathrm{P} 1$

0,1

N, $0.4595828237,-1.3492834725,0.6136041491$ $\mathrm{P},-0.4541904522,0.0029856284,1.0471560801$ $\mathrm{N}, 0.6015169923,1.2692321755,0.7876013471$ $\mathrm{N},-1.0229320573,0.0959432174,2.5235081442$ $\mathrm{N},-1.5864410599,0.0833631363,-0.199151387$ $\mathrm{H},-1.8341754962,-0.4872246825,2.6961517791$ C, $0.1941801219,-2.4956631274,0.0940801918$ C, $1.8633922282,1.4206601042,1.0066888974$ C, $-2.1473275455,1.0718952642,-0.8124975087$ $\mathrm{N},-0.9941071871,-3.2089437271,0.1589036951$ $\mathrm{N}, 1.199603697,-3.1661212229,-0.616442472$ $\mathrm{N},-2.7661387613,0.8196842081,-2.0497963045$ $\mathrm{N},-2.2326442223,2.3945826733,-0.4239175036$ $\mathrm{N}, 2.6629715342,0.7552581905,1.9130963304$ $\mathrm{N}, 2.556589804,2.3850680005,0.2554969378$ C,-2.1675344606,2.8206430232,0.9684531217 C,-2.1992940579,3.4899329543,-1.3825104861 C, $-2.4538861999,-0.4367026618,-2.7117929277$ C,-4.1482862748,1.24659344,-2.2556536155 C, $1.8914304307,2.913455607,-0.9258269168$ C, $3.35997555555,3.3873911983,0.9529044514$ C,2.1284334982,0.0968235381,3.0988458478 C.4.0573877401,0.442600993,1.6346782522 C, $2.3781671374,-2.4003990818,-0.9916545227$ C, $1.4888584893,-4.5682906453,-0.3261386171$ C, $-1.9626789239,-2.9528552713,1.2113604686$ C,-1.5138306403,-3.9552670779, -0.9786160465 $H,-2.7022857206,-0.34339668009,-3.7734375239$ $\mathrm{H},-3.0204448541,-1.280672413,-2.2938408216$ $\mathrm{H},-1.3941936371,-0.6572205176,-2.6056446819$ $\mathrm{H}_{-}-4.3799350383,2.1124873732,-1.6403416848$ $\mathrm{H},-4.850558045,0.4421009097,-1.9903175214$ H,-4.3144297745,1.509532814,-3.3052181037 H,-3.1143038722,4.0955595461,-1.3399901422 $\mathrm{H},-2.0766610112,3.1079449375,-2.3933087616$ H,-1.3542797459,4.1494491774,-1.1499777928 H,-3.0108527649,3.4924809842,1.1733182173 $\mathrm{H},-1.2327163719,3.3521256355,1.1720066991$ $\mathrm{H},-2.2086522618,1.9677118406,1.6426965826$ $\mathrm{H}, 1.1349654921,3.6697437636,-0.6743176113$ $H, 1.3958985306,2.1088592314,-1.4641126728$ $\mathrm{H}, 2.6440698967,3.3744366223,-1.5724735922$ $H, 3.7248180769,2.9983172761,1.9001999813$ $\mathrm{H}, 2.7655227867,4.2892676205,1.1618327785$ $\mathrm{H}, 4.2188594602,3.6804687032,0.3408691719$ $H, 1.1056396653,0.4138401301,3.2944169092$
$\mathrm{H}, 2.764343884,0.3497226966,3.9561353519$ $\mathrm{H}, 2.1216819094,-0.9918075566,2.9754719831$ H,4.1964615455,-0.6456254342,1.6505638069 $H, 4.7264790563,0.8746223539,2.3902353745$ $\mathrm{H}, 4.3437637239,0.8164311403,0.6545620517$ $\mathrm{H},-2.7207247411,-2.2226458231,0.9052277453$ $\mathrm{H},-1.4521200116,-2.5819679899,2.0979150836$ $\mathrm{H},-2.4612471035,-3.8941600041,1.4662255679$ $\mathrm{H},-1.7265416037,-4.9978312521,-0.7101162242$ $\mathrm{H},-0.7968222376,-3.9422274827,-1.7963072645$ $\mathrm{H},-2.4489018605,-3.4999251347,-1.3285788796$ $\mathrm{H}, 0.6144085263,-5.061599725,0.0908509904$ H,2.3095395629,-4.6545877347,0.4012401369 $\mathrm{H}, 1.7875700363,-5.0946103466,-1.2384146114$ $\mathrm{H}, 2.0845156005,-1.4009743706,-1.3039318327$ $\mathrm{H}, 2.8778364138,-2.9103346408,-1.8208347764$ $\mathrm{H}, 3.0906737781,-2.3008780375,-0.1611353199$

$H F=-1483.0439286 \quad N I m a g=0$

$3 \mathrm{bH}+$

Brutoformula: C15H38N10P1(1+) 1,1

N,- $0.2598175353,1.3938236797,-0.3504567355$ $P, 0.3659236768,-0.0775127974,-0.6523981923$ $\mathrm{N}, 1.6732737773,-0.3151557361,0.2976255823$ C, $-0.8201204817,0.457181553,2.4243618519$ $\mathrm{N},-0.5060442848,-1.4382141045,-0.4943802611$ $\mathrm{N}, 0.6847065481,0.0122933462,-2.3118036706$ C,-1.1032157132,1.9633970517,0.4687296833 C, $2.9678352079,-0.2530093999,0.1210145402$ C, $-1.7601621135,-1.8096598573,-0.4699316414$ $\mathrm{N},-1.5665869689,1.4457964173,1.6529761099$ $\mathrm{N},-1.5883571672,3.2063944443,0.128751944$ N,-2.8303113915,-1.1074225417,-0.968353883 $\mathrm{N},-2.0539108505,-3.016774601,0.1167111729$ $\mathrm{N}, 3.7633921833,-1.1040141055,0.8418915007$ $\mathrm{N}, 3.6214251439,0.6088813017,-0.733831382$ C,-1.0438329128,-3.6662891285,0.9486467648 C, $-3.0405729385,-3.9383878177,-0.4549931959$ C,-4.1676249921,-1.1751131306,-0.3830686367 C,-2.7154262645,-0.211653826,-2.1150180302 C, $3.1334463734,1.9563603264,-0.9976077793$ C,4.8618797893,0.257189827,-1.4217748401 C, $5.0432885162,-0.6878816613,1.4184569201$ C,3.1675619763,-2.2796006941,1.4704040676 C,-1.4044329766,3.6927535265,-1.2359305339 C,-1.734073328,4.2738500317,1.1237903074 C,-2.9079973152,1.7231479923,2.1650910686 $\mathrm{H}, 1.109350769,-0.8156895112,-2.7117425273$ $\mathrm{H}, 1.1394346735,0.8588995808,-2.6269278253$ $\mathrm{H},-4.8830987149,-1.6798647912,-1.0411471233$ $\mathrm{H},-4.5308106969,-0.1560478981,-0.2162329207$ H, $-4.1397236914,-1.6944577407,0.5722008769$ H,-3.4535743266,-0.5004871249,-2.8710109035 $\mathrm{H},-1.7231754831,-0.2711343163,-2.5534963507$ $\mathrm{H},-2.9139580571,0.8255006242,-1.8265135001$ $H,-2.5349420014,-4.8593001031,-0.7619904597$ 
H,-3.5094524543,-3.5055212975,-1.33494744782 $\mathrm{H},-3.8156844464,-4.1989147949,0.271432437$ $\mathrm{H},-1.5492319507,-4.3265530585,1.656974831$ $\mathrm{H},-0.4721223548,-2.9188329918,1.4922223418$ $\mathrm{H},-0.3488744811,-4.26171944446,0.3452219707$ $\mathrm{H}, 4.9881177143,-0.7658332664,2.509008305$ $H, 5.2604670027,0.3471021269,1.166298558$ $H, 5.8659561968,-1.3201043804,1.0715227712$ $\mathrm{H}, 3.9253292326,-3.0641463711,1.5341580097$ $\mathrm{H}, 2.3293550636,-2.6298853628,0.8741611146$ $\mathrm{H}, 2.8082855466,-2.0560289495,2.4817405292$ $\mathrm{H},-3.4902028661,2.2762146136,1.4320094805$ $\mathrm{H},-2.8801337712,2.2924585539,3.1000750809$ H,-3.4131904814,0.7730765209,2.3670829847 $\mathrm{H},-1.2794401184,-0.5347950988,2.3543111813$ $\mathrm{H},-0.8193554575,0.757751806,3.476834904$ $\mathrm{H}, 0.2089897762,0.3898003312,2.080135496$ $\mathrm{H},-1.4877363369,2.8707598182,-1.9417376643$ $\mathrm{H},-0.4242998565,4.1662969549,-1.3692116986$ $\mathrm{H},-2.1799155295,4.4318097033,-1.4488961278$ $\mathrm{H},-2.7447864317,4.691762205,1.1163731011$ $\mathrm{H},-1.0287381825,5.0799717754,0.8956987982$ $\mathrm{H},-1.5102423979,3.9049705225,2.1212931041$ $H, 5.0670796949,-0.8050555637,-1.3102488467$ $\mathrm{H}, 5.7207676148,0.8268663848,-1.0500086303$ $\mathrm{H}, 4.7494826204,0.4777265945,-2.4882229645$ $\mathrm{H}, 2.9527977035,2.109547199,-2.0682022956$ $H, 3.8845032624,2.6910580908,-0.6847304337$ $\mathrm{H}, 2.2102149216,2.1425251592,-0.4544511605$

$H F=-1051.09061 \quad \mathrm{NImag}=0$

\section{$3 c$}

\section{Brutoformula: C7H21N10P1}

\section{0,1}

N,1.0735923712,0.9997441605,0.3081004148 $\mathrm{P}, 0.0733615783,-0.35835558695,0.5040993518$ $\mathrm{N},-1.3393639628,-0.0665392359,-0.3602232183$ $\mathrm{N},-0.2827278531,-0.7232714912,1.9964977934$ $\mathrm{N}, 0.805027635,-1.5820951849,-0.3777503656$ $\mathrm{C}, 0.5758553712,-0.9189274059,3.1667486185$ C, $0.7448854641,2.2040807915,-0.0261063748$ C,-2.4939727567,-0.6064600466, -0.0858857931 C,2.0142954733,-1.7186788268,-0.7909465964 $\mathrm{N}, 1.6249747898,3.245593171,0.2245595995$ $\mathrm{N},-0.4148698875,2.5921067427,-0.6466292674$ $\mathrm{N}, 2.4247586727,-2.9546007047,-1.2769223764$ $\mathrm{N}, 3.0027706069,-0.7584384697,-0.8202650061$ $\mathrm{N},-2.8327091689,-1.2123146215,1.0783060061$ $\mathrm{N},-3.4896075694,-0.55213344417,-1.0451334258$ $\mathrm{H}, 2.7463029069,0.1030100998,-0.3422730896$ $\mathrm{H}, 3.9513983552,-1.0811111287,-0.7004693197$ H,1.6554811158,-3.5971073546,-1.3983749539 $\mathrm{H}, 3.0719220383,-2.9360193323,-2.0527180774$ $H,-4.440408712,-0.4430625756,-0.7247311$ H, $-3.2448498315,-0.0190104999,-1.8653433146$ H,-3.5548129579,-1.9151277165,1.0693227099 $\mathrm{H},-2.043978642,-1.273573118,1.7458776974$
$\mathrm{H},-1.0954730226,1.8373394612,-0.7453237072$ $\mathrm{H},-0.7684801439,3.5114864077,-0.428951512$ $H, 2.5215480429,2.9507707298,0.5796076551$ $\mathrm{H}, 1.664245501,3.9858834357,-0.4611281969$ C, $1.8410090895,-1.7497222476,2.8620429744$ C, $-0.2674287921,-1.6794145584,4.2101294191$ C, $0.9913979454,0.4428068884,3.7652937131$ $\mathrm{H}, 2.4060103495,-1.9509252243,3.7785729123$ $\mathrm{H}, 2.5041002217,-1.2175545198,2.1735550511$ $H, 1.5713290609,-2.704627334,2.4044292447$ $H, 1.5796736594,0.3122954997,4.68082811$ $\mathrm{H}, 0.1019175051,1.0316867185,4.004218927$ $\mathrm{H}, 1.5873232711,1.0097058193,3.0464286481$ $\mathrm{H}, 0.2887788278,-1.8269096465,5.1417020747$ $H,-0.5561590336,-2.6604448964,3.8218093892$ H,-1.1784191043,-1.1189774669,4.4383793452

$H F=-1168.6124375 \quad \mathrm{NImag}=0$

\section{$3 \mathrm{cH}+$}

Brutoformula: $\mathrm{C} 7 \mathrm{H} 22 \mathrm{~N} 10 \mathrm{P} 1(1+)$ 1,1 N,- $-0.1109602358,1.6877735084,-0.2154891574$ $P, 0.0658144362,0.0857299604,0.1399831293$ $\mathrm{N},-1.2755905191,-0.7922558026,-0.2158135937$ $\mathrm{H},-3.2955927059,2.412655972,-0.3598298951$ $\mathrm{N}, 1.346973288,-0.539947738,-0.6854018756$ $\mathrm{N}, 0.3474799708,0.0973963655,1.7774251649$ C,- $-1.2293943112,2.3681689946,-0.3471641984$ C,- $-1.4314156657,-1.8438813491,-0.9917539058$ C, $2.5069238347,0.0560245114,-0.8770300463$ $\mathrm{N},-2.4707850613,1.8377545151,-0.3167779501$ N,-1.1446244135,3.7151601556,-0.5070673238 $\mathrm{N}, 2.7280341758,1.3766284651,-0.7132745672$ $\mathrm{N}, 3.5634045665,-0.7008961763,-1.2675373108$ $\mathrm{N},-0.438568303,-2.4956377367,-1.6300915991$ $\mathrm{N},-2.6958035622,-2.3186162783,-1.1657210251$ $H, 3.4194259074,-1.6896928488,-1.3834875289$ $\mathrm{H}, 4.3890310637,-0.292779733,-1.6745217761$ H,3.6516382634,1.7727813537,-0.7691238909 $\mathrm{H}, 1.9263783842,1.9693624015,-0.5220354415$ $\mathrm{H},-3.4054353697,-1.9698695524,-0.5423635488$ H,-2.8535568136,-3.2280636255,-1.5697115278 $H,-0.6352528485,-3.2139297486,-2.3076445796$ $H, 0.4847762987,-2.0682593495,-1.5850042454$ H, $-1.9262595647,4.2536061953,-0.8437534625$ $\mathrm{H},-0.2275143869,4.1158771921,-0.6104290261$ $\mathrm{H},-2.5531423429,0.8296077349,-0.2341137556$ C, $0.3711116555,-1.013342901,2.7775956158$ $\mathrm{H}, 0.1963268456,1.0092465529,2.1884756577$ C, $1.0177258845,-2.2664474702,2.1729020193$ C,-1.0592702411,-1.3241710388,3.2537555797 C, $1.2207130866,-0.5124821936,3.9559328925$ $\mathrm{H}, 2.2415009356,-0.2928459711,3.6352507048$ H, 1.2598930429,-1.2673670629,4.7444966372 $\mathrm{H}, 0.7930476023,0.3961332459,4.3918788623$ $\mathrm{H},-1.0488642724,-2.1088393297,4.014969624$ $\mathrm{H},-1.682359617,-1.6566900305,2.4213967354$ 
$\mathrm{H},-1.5222259496,-0.4361733123,3.6931982589$ $\mathrm{H}, 2.03389968,-2.0609025712,1.8311675937$ $\mathrm{H}, 0.4418684357,-2.658944781,1.3315298437$ $H, 1.0634507549,-3.0500143985,2.9323399749$

$H F=-1169.0676254 \quad \mathrm{NImag}=0$

\section{$3 d$}

Brutoformula: C9H17N10P1

0,1

$\mathrm{N},-1.0956514616,-0.4866653635,1.5606514054$ $P,-0.7939116136,-0.4196147175,-0.0655560064$ $\mathrm{N},-0.0019547135,-1.8604768068,-0.4780850005$ $\mathrm{N},-0.0360291648,0.9283365578,-0.5127315127$ $\mathrm{N},-2.2591303417,-0.5389816327,-0.8276304855$ C,1.0941615424,1.5097930887,0.0548598602 C,-1.1971255456,-1.512507525,2.3396558133 C, $0.8453895835,-1.9634371321,-1.4559183112$ C,-2.911786802,0.4095160598,-1.4258203162 $\mathrm{N},-1.1126788285,-2.8311485154,1.9742867423$ $\mathrm{N},-1.4060401997,-1.2944811416,3.6886993035$ $\mathrm{N},-4.2345868875,0.1817982294,-1.7608787306$ $\mathrm{N},-2.42268442,1.630369134,-1.786327021$ $\mathrm{N}, 1.507291605,-3.1629931098,-1.6438705612$ $\mathrm{N}, 1.1670729285,-0.9862180785,-2.3578969475$ $\mathrm{H},-3.0735576173,2.3967367745,-1.8614799436$ $\mathrm{H},-1.4829375777,1.8151939305,-1.4133640574$ H,-4.5721558776,0.6112209106,-2.6099757056 $\mathrm{H},-4.5190688269,-0.7774881135,-1.6296129157$ $\mathrm{H}, 2.0737842704,-1.0432357916,-2.7971494959$ $\mathrm{H}, 0.8616642989,-0.0498186738,-2.0868383743$ H,1.1136458172,-3.9345030512,-1.1277340777 H, 1.783607662,-3.3909176559,-2.5875811935 H, $-1.6445446878,-0.3381215042,3.9056924414$ $H,-1.9360704281,-1.9889619956,4.194247981$ $\mathrm{H},-0.8207449544,-3.48489923988,2.6855224472$ $\mathrm{H},-0.7124030244,-2.9682126014,1.0458993722$ C,3.4069071017,2.828038414,1.0566671865 C, $1.5350901639,2.7426386853,-0.4768018798$ C,1.8599256105,0.9587870643,1.1058494433 C,2.9901977237,1.6105559351,1.5929272997 C,2.6645995941,3.3863072161,0.0142494156 $\mathrm{H}, 0.964491782,3.184925388,-1.2869812384$ $H, 1.5588432084,0.0173946047,1.5486982201$ $H, 3.551172213,1.157339149,2.4044364363$ $\mathrm{H}, 2.9676990285,4.3336543741,-0.4205647533$ H,4.287518838,3.3300771332,1.440455159

$H F=-1242.4376422 \quad \mathrm{NImag}=0$

\section{$3 \mathrm{dH}+$}

Brutoformula: C9H18N10P1(1+) 1,1 $\mathrm{N},-2.1821824907,0.6945710373,-0.5778329429$ $\mathrm{P},-0.7685484452,-0.0397297823,-0.1718252081$ $\mathrm{N},-0.7251349893,-0.5474869359,1.3781977316$ $H,-2.334118286,0.5667690042,1.995940875$
$\mathrm{N},-0.4296836912,-1.2923651538,-1.1778005639$ $\mathrm{N}, 0.34451575,1.1971093079,-0.3824794743$ C, $-3.1375988161,1.1247414598,0.2208116525$ C, $-0.382401463,-1.7091192032,1.8982675977$ C, $-0.6566758235,-1.3349350643,-2.4779588962$ $\mathrm{N},-3.0989326175,1.0830670855,1.5706918569$ $\mathrm{N},-4.2493110546,1.6572579952,-0.34596527$ $\mathrm{N},-1.4439974767,-0.4662991163,-3.1447538062$ $\mathrm{N},-0.0803546269,-2.3296817992,-3.1932942898$ $\mathrm{N},-0.0542174519,-2.8070334517,1.1919340147$ $\mathrm{N},-0.3914432254,-1.8147169775,3.2527933573$ $\mathrm{H}, 0.6385939004,-2.8794884042,-2.7544312053$ $\mathrm{H},-0.2063324755,-2.4202358085,-4.1877208763$ H,-1.59846899017,-0.5418237932,-4.1367523311 $\mathrm{H},-2.0014111554,0.1804412381,-2.5957981232$ $H,-0.4175745026,-0.9553252973,3.777369741$ $H, 0.0001818999,-2.6203232428,3.7137615039$ $\mathrm{H},-0.1092988447,-2.7404502698,0.1791126777$ $\mathrm{H}, 0.1722587367,-3.6801173842,1.6383426063$ H,-4.242063088, 1.8164114333,-1.3393971251 H, $-4.9337007828,2.1535840214,0.2009885203$ $\mathrm{H},-3.9190026221,1.2844690606,2.1197531291$ C, $1.7187041199,1.2220529605,-0.0322359647$ $\mathrm{H},-0.0750090415,2.1011246487,-0.5492007946$ C, $4.4372495489,1.3579025419,0.642089063$ C, $2.4844381169,0.0545189757,0.0442027864$ C,2.324346833,2.4572082558,0.2262689249 C,3.6748759898, 2.521756308,0.5524995368 C,3.8330614757,0.1293381162,0.3885037315 $\mathrm{H}, 2.0385298571,-0.9051389302,-0.1848943676$ $\mathrm{H}, 1.7367031259,3.3681831867,0.1721325284$ $\mathrm{H}, 4.1297456889,3.4867835721,0.7434661863$ $\mathrm{H}, 4.4166278342,-0.7827100305,0.4442431309$ H,5.4876289959,1.409690436,0.9009700878

$H F=-1242.8778344 \quad N I m a g=0$

\section{4}

Brutoformula: C5H17N6P1

0,1

N, $-0.3319741598,-0.864077156,-1.4122870758$ P, $-0.1870406658,-0.8653685974,0.2713872978$ N, $1.4618294573,-0.760483276,0.5244755414$ $H, 2.3785758479,2.2291481763,1.2644505563$ $H, 3.8260988676,-0.9284669435,1.0290220374$ C, $0.4186257517,0.0144755138,-2.2963509902$ C, $-1.3607512611,-1.6572331854,-2.0735409254$ H,4.2186146392,0.7168058159,0.8527042145 $\mathrm{N},-0.9531170009,-2.0111958518,1.0082235053$ $\mathrm{N},-0.8795569157,0.644063822,0.7905647479$ C,2.2207057042,0.2519384195,0.7678223892 $\mathrm{N}, 3.534952075,0.0315522457,1.1397813847$ $\mathrm{N}, 1.8686554682,1.5813960268,0.6816798747$ $H, 0.8597707502,1.7258780423,0.6306473282$ $\mathrm{H},-0.5069642377,-2.9216162656,1.0002648043$ C, $-0.9985997606,0.7544057805,2.2565687809$ C,- $-2.1292564077,1.0497258997,0.1325274002$ $\mathrm{H},-0.9104642247,-2.3049616139,-2.8361884247$ 
$\mathrm{H},-2.1054475924,-1.0173781945,-2.5690137175$ H, $-1.8684239285,-2.27961929,-1.3378400511$ $\mathrm{H}, 0.8806084612,-0.5653418914,-3.1049874828$ $H, 1.2130036677,0.5263603157,-1.7558326021$ $\mathrm{H},-0.2279623473,0.7763940384,-2.75668249$ $\mathrm{H},-0.064339346,0.458865924,2.7365006207$ $\mathrm{H},-1.7932534248,0.110453423,2.64878688853$ $\mathrm{H},-1.2104707364,1.7960030182,2.5206488438$ $\mathrm{H},-2.3573658719,2.0831884353,0.4115092054$ $\mathrm{H},-2.9784844121,0.4175305307,0.4255283786$ $\mathrm{H},-2.0179683958,1.007556838,-0.95037004$

$H F=-870.8280428 \quad \mathrm{NImag}=0$

\section{$4 \mathrm{H}+$}

Brutoformula: $\mathrm{C} 5 \mathrm{H} 18 \mathrm{~N} 6 \mathrm{P} 1(1+)$

1,1

N,-0.4559363438, $0.0525417072,-1.414957727$ P, $-0.3469333325,-0.1789081725,0.2259755441$ $\mathrm{N}, 1.0957798426,-0.4253331494,0.8996613911$ $\mathrm{H}, 2.111193327,-3.5189742581,0.5425195428$ $\mathrm{H}, 3.436393271,-0.4347427204,1.6232761236$ C, $0.0605943796,1.3064428825,-1.9968154121$ C, $-0.4489062948,-1.0579345397,-2.3851224189$ $\mathrm{H}, 3.7689255483,-2.1252535886,1.442095696$ $\mathrm{H},-2.6004461995,1.2567242625,-0.3687877516$ $\mathrm{N},-0.9133239356,1.2059893019,0.9159084335$ C, $1.8673075045,-1.4937951085,0.8971331234$ $\mathrm{N}, 3.1349274276,-1.3507380493,1.333710791$ $\mathrm{N}, 1.489473109,-2.7280393679,0.4877423491$ $\mathrm{H}, 0.5189623777,-2.8958039089,0.2631763247$ $\mathrm{N},-1.301786264,-1.5632924719,0.4474694692$ C, $-0.3411427468,1.8237923331,2.1225207383$ C, $-2.2428340313,1.7185906707,0.551186969$ $H, 0.564437918,-1.2607106613,-2.7485126885$ $\mathrm{H},-1.0714286381,-0.7790817003,-3.2383706415$ $\mathrm{H},-0.8550294283,-1.967376122,-1.9494445019$ $\mathrm{H}, 1.0871755551,1.1804318933,-2.3560828182$ $\mathrm{H}, 0.0410468765,2.108241985,-1.2617847998$ $\mathrm{H},-0.5733443343,1.5901985738,-2.8398570758$ $\mathrm{H}, 0.6561743446,1.434376545,2.303313199$ $\mathrm{H},-0.9714427036,1.6287361582,2.9963116115$ $\mathrm{H},-0.2796039143,2.9045755135,1.9709198753$ $\mathrm{H},-2.1840523917,2.7974620482,0.3858388281$ $\mathrm{H},-2.9673673815,1.5294405586,1.3501374456$ H,-1.4127006688,-1.8265671878,1.4219095786 H,-2.2045393156,-1.5707094502,-0.0162613535

$$
\mathrm{HF}=-871.2640131 \mathrm{NImag}=0
$$

\section{5}

Brutoformula: C4H15N8P1

0,1

$\mathrm{N}, 0.3719417197,0.9868436289,0.6679623536$ $\mathrm{P}, 0.0683341409,-0.6781907428,0.4913903543$ $\mathrm{N},-1.2750526998,-0.8442180813,-0.483706794$ $\mathrm{N},-0.1789425407,-1.5242194412,1.8064476195$
N,1.4313614858,-1.1795119696,-0.395960552 $\mathrm{H}, 0.6884599636,-1.7853951345,2.2683458299$ C, $1.5362458834,-2.6159623963,-0.6650630146$ C, $1.9388406525,-0.3653740353,-1.4986499066$ C, $-1.8988367419,0.0206942205,-1.2056090651$ C, $0.1607210655,1.6142685452,1.7891107606$ $\mathrm{N}, 0.3010866199,2.9945667201,1.8025863147$ $\mathrm{N},-0.205433517,1.0575433524,2.9759595024$ $\mathrm{N},-1.5380322013,1.3285225715,-1.4447493759$ $\mathrm{N},-3.0695686392,-0.3637014664,-1.8390511128$ $\mathrm{H},-0.4476481376,0.0575532126,2.9215517958$ $\mathrm{H},-0.6543556292,1.63839588222,3.6661065404$ $\mathrm{H}, 0.5764880517,3.4126094422,2.6799734326$ $\mathrm{H}, 0.8062104017,3.3510177384,1.0046864285$ $\mathrm{H},-2.2865310966,1.9799922579,-1.6295844334$ $\mathrm{H},-0.794394355,1.6658785531,-0.8367691634$ H, $-3.2613049265,0.0497649683,-2.7401811727$ $\mathrm{H},-3.2388117345,-1.3573742412,-1.7859369631$ H,1.3603586529,-0.5076197303,-2.4249413711 $\mathrm{H}, 2.9761630997,-0.6508714862,-1.7018158466$ $H, 1.9179456082,0.6873166167,-1.2244129392$ $\mathrm{H}, 1.0129722145,-2.9028781453,-1.5890833109$ H,1.1095287273,-3.1834599087,0.1610769662 $\mathrm{H}, 2.592253931,-2.88619093,-0.769682879$

$\mathrm{HF}=-941.0772395 \mathrm{NImag}=0$

\section{$5 \mathrm{H}+$}

Brutoformula: C4H16N8P1(1+) 1,1 $\mathrm{N}, 0.7491542416,1.2615448038,0.0224209358$ $\mathrm{P}, 0.4583223591,-0.3037746128,-0.3593607103$ $\mathrm{N},-0.9260599975,-0.636428353,-1.1345497922$ $H, 0.1592244938,-3.3515219579,0.5695910967$ $\mathrm{N}, 1.7942988368,-0.6617345792,-1.28028986$ $\mathrm{N}, 0.3874195463,-1.2699141845,1.0179199356$ $\mathrm{H},-1.3339612117,-2.3835320551,0.5121918233$ $\mathrm{H}, 2.3082535565,-2.146756533,1.3637189624$ C,- $-1.4767987865,0.0765386206,-2.0945082337$ C, $0.3034125986,1.9316469751,1.0689978046$ $\mathrm{N}, 0.5465423777,3.2631603382,1.1076419447$ N, $-0.3977204476,1.4009757851,2.093496401$ $\mathrm{N},-1.0840767691,1.3195799711,-2.4615541947$ $\mathrm{N},-2.5074244764,-0.4693365797,-2.7766297735$ $\mathrm{H},-0.5213681361,0.3959243036,2.1191972685$ $\mathrm{H},-0.6773227569,1.9507545216,2.8896864543$ $H, 0.3645188516,3.8169926845,1.9288446126$ $H, 1.1610537222,3.6452739222,0.4073380851$ $\mathrm{H},-1.536315696,1.8233828895,-3.2071867875$ $\mathrm{H},-0.3793955162,1.7951506708,-1.9151891453$ $\mathrm{H},-3.0696071885,0.0555452494,-3.4259841363$ H, $-2.8166574698,-1.3885218345,-2.5066908224$ H,1.4136732657,-1.6377961266,2.8139706586 $\mathrm{H}, 2.1836543412,-0.4277754018,1.7787153106$ $\mathrm{H}, 2.4529255775,0.0714188601,-1.4955406221$ $\mathrm{H},-0.5935775447,-2.7884000468,2.0738321077$ H,1.7808543913,-1.4395641751,-1.9233376906 C,1.6487992598,-1.377973991,1.7799009948 
C, $-0.3918214236,-2.5248591645,1.0333573723$

$$
\mathrm{HF}=-941.5193296 \mathrm{NImag}=0
$$

\section{6}

Brutoformula: C5H17N6P1

0,1

$\mathrm{N}, 2.0177089245,0.0530926684,-2.7721940046$ $P, 0.8989224619,0.9877250349,-1.8742002639$ $\mathrm{H},-1.3044951247,0.4770077374,3.0553424935$ $\mathrm{N}, 1.8766023186,1.895474821,-0.8287143319$ $\mathrm{N}, 0.2058431351,-0.2811721885,-1.0492174223$ H,1.6917881914,-0.8857411492,-2.9619919432 $\mathrm{H}, 2.326501976,0.5102071498,-3.622264113$ $\mathrm{H}, 2.8277846222,1.5630462824,-0.7459651208$ $H, 1.8401617146,2.8838745502,-1.0450122843$ $\mathrm{N}, 0.008968043,2.0566552403,-2.6096951679$ C, $-0.2479731836,-0.4247783472,0.1557736712$ $\mathrm{N},-0.4178160421,-1.7223809327,0.6377106371$ $\mathrm{N},-0.5886801173,0.5607348311,1.056870894$ C,-1.6697101049,-2.1059164837,1.2882502733 C, $0.2068738413,-2.808303695,-0.1057774308$ C, $-0.3659789151,0.414369698,2.4902213346$ C, $-1.0097190011,1.895606394,0.6490896631$ $\mathrm{H},-0.3659422237,-3.0797009092,-1.0024225963$ $H, 0.2730491531,-3.6824620931,0.5477452709$ $\mathrm{H}, 1.2076164479,-2.5166796659,-0.4166648737$ $\mathrm{H},-2.3285622273,-2.6236679784,0.577488718$ $\mathrm{H},-2.1957599492,-1.2293455795,1.6576909773$ $\mathrm{H},-1.4777089949,-2.7799375129,2.1289572656$ $\mathrm{H},-0.2520355908,2.6414833373,0.9078534817$ $\mathrm{H},-1.9425956053,2.148050151,1.1674417117$ $\mathrm{H}_{-}-1.1748282467,1.9439365165,-0.4249718589$ $H, 0.2892839248,1.2218526465,2.836953197$ $\mathrm{H}, 0.1126937409,-0.5380911522,2.7052539096$ $\mathrm{H},-0.6986389305,1.6765942375,-3.2289748412$

$H F=-870.826765$ NImag $=0$

\section{$6 \mathrm{H}+$}

Brutoformula: C5H18N6P1(1+)

1,1

N,1.7499400522,2.2422123075,-1.3298234041 $\mathrm{P}, 0.536795591,1.2616484684,-1.8914803212$ $\mathrm{H},-0.221658381,-0.2890128397,3.3084315342$ $\mathrm{N},-0.6217614472,2.3888220011,-2.2847313953$ $\mathrm{N},-0.2203706552,0.1191710151,-1.08514187$ $\mathrm{H}, 2.6766173579,1.8605419388,-1.2025942985$ $\mathrm{H}, 1.5274058457,3.0253418031,-0.7329290275$ $\mathrm{H},-0.3742430597,3.1409390323,-2.915638334$ $\mathrm{H},-1.5615495923,2.0434731863,-2.4288024149$ $\mathrm{N}, 1.3364450805,0.4646795044,-3.1079883442$ C, $-0.26798884898,-0.3825237664,0.1391025942$ $\mathrm{N},-0.5199602605,-1.7085195692,0.2732440174$ $\mathrm{N},-0.1023133619,0.3527868219,1.2774012778$ C, $-1.3317564011,-2.2571581804,1.3665034232$ C, $-0.3433596275,-2.6048073609,-0.8710379399$
C, $0.5038156575,-0.1929485737,2.4954019237$ C, $-0.4447572023,1.7711600931,1.3472441898$ $\mathrm{H},-1.2339220755,-2.6223584692,-1.5072155966$ $\mathrm{H},-0.158158635,-3.6114915812,-0.4935203028$ $\mathrm{H}, 0.5123040907,-2.2910912212,-1.46372262$ $\mathrm{H},-2.1643879044,-2.8173840684,0.9335261248$ $\mathrm{H},-1.7438365131,-1.4572272217,1.9760281561$ $\mathrm{H},-0.7522605985,-2.9340189069,1.9994327204$ $H, 0.4509512039,2.3935827402,1.4437674112$ $\mathrm{H},-1.0683491207,1.9451996726,2.2287472311$ $\mathrm{H},-1.0062225205,2.0743262237,0.4668157387$ $H, 1.2950300088,0.4866174695,2.8243253096$ $H, 0.9492681912,-1.1643063166,2.2948206376$ $H, 0.9133344675,-0.3795185933,-3.4668797058$ $H, 1.8377005511,0.9991026965,-3.8056339142$

\section{$H F=-871.2629915 \quad \mathrm{~N} / \mathrm{mag}=0$}

\section{7}

Brutoformula: C10H27N8P1

0,1

N, $-0.9231908927,-0.7678445567,-0.1894494984$ $\mathrm{P},-0.4527772859,0.7723066204,0.2953028468$ $\mathrm{N}, 1.190255195,0.6384750375,0.0101501635$ N, $-1.0522003729,1.2494268238,1.6791060991$ C, $2.1826909089,1.0227532024,0.7504711457$ $\mathrm{H},-1.1023395393,0.5031049921,2.3656135031$ C, $-1.9216977405,-1.2254329869,-0.8585094534$ $\mathrm{N},-0.8739023829,1.9769920205,-0.8277725766$ $\mathrm{H},-0.5526020875,1.8116750814,-1.7726118424$ $\mathrm{H},-1.8417110449,2.2663875537,-0.7995887284$ $\mathrm{N},-1.8386943718,-2.5244000933,-1.3756700854$ $\mathrm{N},-3.1039455027,-0.5657463936,-1.1813141367$ $\mathrm{N}, 2.2155507758,2.08688849643,1.630543381$ $\mathrm{N}, 3.3764114168,0.3146361196,0.6654656607$ C, $1.3598680079,3.2567240184,1.456863366$ C, $2.8423216207,1.9809344626,2.941607721$ C. $4.6653826758,0.9963111644,0.6304282066$ C, $3.3640087146,-0.9754023157,-0.0088369333$ C, $-3.758737405,0.3542055443,-0.2630134051$ C, $-3.8228269652,-0.8051246406,-2.4233373846$ C,-2.9255510603,-3.4668062165,-1.1162577598 C, $-0.5235210132,-3.1528611532,-1.3739322064$ $\mathrm{H},-4.0223730242,0.1534221309,-2.9177517614$ H,- $-4.7909652758,-1.2980143608,-2.2573227043$ H, $-3.2254899752,-1.4240572483,-3.0893076858$ $\mathrm{H},-3.9613912835,1.3145657824,-0.7538121297$ $\mathrm{H},-3.1405995496,0.5407319475,0.6146385045$ $\mathrm{H},-4.7254823113,-0.0575143756,0.0593121972$ $\mathrm{H},-3.0250252412,-4.1707693618,-1.9480320953$ $\mathrm{H},-3.8707853852,-2.9442677216,-0.9905984509$ $\mathrm{H},-2.731704936,-4.0437813753,-0.2003697583$ H, $-0.5357712201,-3.9869353317,-2.0815137019$ $\mathrm{H},-0.2491151146,-3.5338196819,-0.3810486256$ $\mathrm{H}, 0.2301416922,-2.4286358344,-1.6745648627$ $\mathrm{H}, 2.0778952921,2.0776619579,3.7221496624$ $\mathrm{H}, 3.5875835567,2.7714644928,3.0962817945$ $H, 3.3285384634,1.013821143,3.0525622804$ 
$H, 0.4673285945,3.2008954435,2.0855317023$ $\mathrm{H}, 1.0314445701,3.3247677683,0.42178764$ $\mathrm{H}, 1.9443541931,4.1505722831,1.704945349$ H,4.1950950379,-1.5786919594,0.3689331651 $H, 3.4728036625,-0.8692721759,-1.096751086$ $\mathrm{H}, 2.4219126985,-1.4814917003,0.1867573777$ $H, 5.3856627421,0.5103410291,1.2975485645$ $\mathrm{H}, 4.5542409569,2.0347883376,0.9326520428$ $\mathrm{H}, 5.0789102042,0.977019564,-0.3872855007$

$H F=-1176.9343537 \quad N I m a g=0$

\section{$7 \mathrm{H}+$}

Brutoformula: C10H28N8P1(1+) 1,1 $\mathrm{N},-0.8513996257,-0.847199008,-0.1754984804$ $P,-0.4797997588,0.1986301135,0.9998880298$ $\mathrm{N}, 0.7437017604,1.143851472,0.537870349$ $\mathrm{H}, 2.3552437238,-1.9520021962,1.2228749836$ C, $2.0428253624,1.1823784085,0.7280703903$ $\mathrm{N},-0.3221745847,-0.7467308792,2.3756666554$ C, $-1.9263273747,-1.0964774882,-0.8955541259$ $\mathrm{N},-1.5954529454,1.3326403023,1.5029388129$ $\mathrm{H},-2.5023816101,1.0332055361,1.8290320608$ $\mathrm{H},-1.5960449662,2.2182252094,1.0182716774$ $\mathrm{N},-3.2155623992,-1.039047331,-0.4276934363$ $\mathrm{N},-1.7598492503,-1.4549292999,-2.1989876963$ $\mathrm{N}, 2.6610384977,2.3996715817,0.6937577899$ $\mathrm{N}, 2.8426420505,0.0916030877,0.9604278634$ C,3.9770597386,2.5967811498,0.0786016344 C, $1.8616302998,3.6162725825,0.8262165868$ C, $2.5376632388,-1.2287822107,0.4200479283$ C, $4.0373645206,0.1505626201,1.8029950527$ C, $-0.4934484262,-1.175979689,-2.8740844325$ C,-2.6031257807,-2.452812923,-2.8630452591 C,- $4.3468509733,-0.6347753015,-1.2631537567$ C, $-3.559856256,-1.3802847919,0.948545149$ H,-1.96535844438,-3.2562653745,-3.2422107028 $\mathrm{H},-3.1518162208,-2.0235178216,-3.7059505792$ H,-3.3092783132,-2.8870327556,-2.1596803245 $\mathrm{H}, 0.2112810056,-2.0069786561,-2.7597669855$ $\mathrm{H},-0.045157314,-0.2746596148,-2.4646772782$ $\mathrm{H},-0.6910990375,-1.0296669015,-3.9380878802$ $\mathrm{H},-5.024740051,-1.4675262,-1.4765727547$ $\mathrm{H},-3.9921393457,-0.2139805962,-2.2011908082$ $\mathrm{H},-4.91508558666,0.1360577069,-0.7338401596$ H,-4.2913071578,-2.1952607504,0.9526198792 $\mathrm{H},-4.0182085578,-0.5300578058,1.466709493$ H,-2.6781219694,-1.7009474516,1.497257788 H, 1.4469463814,3.9335273224,-0.136904586 $\mathrm{H}, 2.5025402687,4.410845256,1.2130979264$ $\mathrm{H}, 1.0437817757,3.4501798138,1.5230304827$ H, 3.8803251918,3.3070986828,-0.7478130945 $\mathrm{H}, 4.356427565,1.6611987899,-0.3245506166$ $H, 4.6999313799,2.9984250248,0.7941851924$ $\mathrm{H}, 4.9583698837,0.0230283207,1.2248979388$ $\mathrm{H}, 3.9869513806,-0.6570857794,2.5395999026$ $H, 4.0789905551,1.0982398888,2.3347385552$
H,3.3919995596,-1.5900501518,-0.1622766147 $H, 1.664973486,-1.1877056391,-0.2269976118$ $\mathrm{H},-0.02985899968,-0.2875236588,3.2289118093$ $H, 0.0827573223,-1.6651425957,2.2582832542$

$H F=-1177.3906705 \quad \mathrm{NImag}=0$

8

Brutoformula: $\mathrm{C} 15 \mathrm{H} 37 \mathrm{~N} 10 \mathrm{P} 1$

0,1

$\mathrm{N}, 0.4595828237,-1.3492834725,0.6136041491$ P, $-0.4541904522,0.0029856284,1.0471560801$ $\mathrm{N}, 0.6015169923,1.2692321755,0.7876013471$ $\mathrm{N},-1.0229320573,0.0959432174,2.5235081442$ $\mathrm{N},-1.5864410599,0.0833631363,-0.199151387$ $\mathrm{H},-1.8341754962,-0.4872246825,2.6961517791$ C, $0.1941801219,-2.4956631274,0.0940801918$ C,1.8633922282,1.4206601042,1.0066888974 C,-2.1473275455, 1.0718952642,-0.8124975087 $\mathrm{N},-0.9941071871,-3.2089437271,0.1589036951$ $\mathrm{N}, 1.199603697,-3.1661212229,-0.616442472$ N,-2.7661387613,0.8196842081,-2.0497963045 $\mathrm{N},-2.2326442223,2.3945826733,-0.4239175036$ $\mathrm{N}, 2.6629715342,0.7552581905,1.9130963304$ $\mathrm{N}, 2.556589804,2.3850680005,0.2554969378$ C, $-2.1675344606,2.8206430232,0.9684531217$ C,-2.1992940579,3.4899329543,-1.3825104861 C, $-2.4538861999,-0.4367026618,-2.7117929277$ C,- $-4.1482862748,1.24659344,-2.2556536155$ C, $1.8914304307,2.913455607,-0.9258269168$ C,3.3599755555,3.3873911983,0.9529044514 C, $2.1284334982,0.0968235381,3.0988458478$ C, $4.0573877401,0.442600993,1.6346782522$ C, $2.3781671374,-2.4003990818,-0.9916545227$ C, $1.4888584893,-4.5682906453,-0.3261386171$ C, $-1.9626789239,-2.9528552713,1.2113604686$ C, $-1.5138306403,-3.9552670779,-0.9786160465$ $\mathrm{H},-2.7022857206,-0.3433966809,-3.7734375239$ $\mathrm{H},-3.0204448541,-1.280672413,-2.2938408216$ $\mathrm{H},-1.3941936371,-0.6572205176,-2.6056446819$ $\mathrm{H},-4.3799350383,2.1124873732,-1.6403416848$ $\mathrm{H},-4.850558045,0.4421009097,-1.9903175214$ $\mathrm{H},-4.3144297745,1.509532814,-3.3052181037$ H, $-3.1143038722,4.0955595461,-1.3399901422$ H,-2.0766610112,3.1079449375,-2.3933087616 $\mathrm{H},-1.3542797459,4.1494491774,-1.1499777928$ $\mathrm{H},-3.0108527649,3.4924809842,1.1733182173$ H,-1.2327163719,3.3521256355,1.1720066991 $\mathrm{H},-2.2086522618,1.9677118406,1.6426965826$ $\mathrm{H}, 1.1349654921,3.6697437636,-0.6743176113$ $\mathrm{H}, 1.3958985306,2.1088592314,-1.4641126728$ $\mathrm{H}, 2.6440698967,3.3744366223,-1.5724735922$ $\mathrm{H}, 3.7248180769,2.9983172761,1.9001999813$ $H, 2.7655227867,4.2892676205,1.1618327785$ $\mathrm{H}, 4.2188594602,3.6804687032,0.3408691719$ $\mathrm{H}, 1.1056396653,0.4138401301,3.2944169092$ $\mathrm{H}, 2.764343884,0.3497226966,3.9561353519$ $H, 2.1216819094,-0.9918075566,2.9754719831$ 
$\mathrm{H}, 4.1964615455,-0.6456254342,1.6505638069$ $\mathrm{H}, 4.7264790563,0.8746223539,2.3902353745$ $\mathrm{H}, 4.3437637239,0.8164311403,0.6545620517$ $\mathrm{H},-2.7207247411,-2.2226458231,0.9052277453$ $\mathrm{H},-1.4521200116,-2.5819679899,2.0979150836$ $\mathrm{H},-2.4612471035,-3.8941600041,1.4662255679$ $\mathrm{H},-1.7265416037,-4.9978312521,-0.7101162242$ $\mathrm{H},-0.79682222376,-3.9422274827,-1.7963072645$ $\mathrm{H},-2.4489018605,-3.4999251347,-1.3285788796$ $\mathrm{H}, 0.6144085263,-5.061599725,0.0908509904$ $\mathrm{H}, 2.3095395629,-4.6545877347,0.4012401369$ $H, 1.7875700363,-5.0946103466,-1.2384146114$ $\mathrm{H}, 2.0845156005,-1.4009743706,-1.3039318327$ H,2.8778364138,-2.9103346408,-1.8208347764 $H, 3.0906737781,-2.3008780375,-0.1611353199$

$H F=-1483.0439286 \quad \mathrm{NImag}=0$

\section{$8 \mathrm{H}+$}

Brutoformula: C15H38N10P1(1+)

1,1

$\mathrm{N},-0.2598175353,1.3938236797,-0.3504567355$ $\mathrm{P}, 0.3659236768,-0.0775127974,-0.6523981923$ $\mathrm{N}, 1.6732737773,-0.3151557361,0.2976255823$ C, $-0.8201204817,0.457181553,2.4243618519$ $\mathrm{N},-0.5060442848,-1.4382141045,-0.4943802611$ $\mathrm{N}, 0.6847065481,0.0122933462,-2.3118036706$ C, $-1.1032157132,1.9633970517,0.4687296833$ C, $2.9678352079,-0.2530093999,0.1210145402$ C,-1.7601621135,-1.8096598573,-0.4699316414 $\mathrm{N},-1.5665869689,1.4457964173,1.6529761099$ $\mathrm{N},-1.5883571672,3.2063944443,0.128751944$ $\mathrm{N},-2.8303113915,-1.1074225417,-0.968353883$ N,-2.0539108505,-3.016774601,0.1167111729 $\mathrm{N}, 3.7633921833,-1.1040141055,0.8418915007$ N,3.6214251439,0.6088813017,-0.733831382 C, $-1.0438329128,-3.6662891285,0.9486467648$ C,-3.0405729385,-3.9383878177,-0.4549931959 C,- $-4.1676249921,-1.1751131306,-0.3830686367$ C, $-2.7154262645,-0.211653826,-2.1150180302$ C,3.1334463734,1.9563603264,-0.9976077793 $\mathrm{C}, 4.8618797893,0.257189827,-1.4217748401$ C, $5.0432885162,-0.6878816613,1.4184569201$ C,3.1675619763,-2.2796006941,1.4704040676 C,-1.4044329766,3.6927535265,-1.2359305339 C,-1.734073328,4.2738500317,1.1237903074 C,-2.9079973152,1.72314799923,2.1650910686 $\mathrm{H}, 1.109350769,-0.8156895112,-2.7117425273$ $\mathrm{H}, 1.1394346735,0.8588995808,-2.6269278253$ $\mathrm{H},-4.8830987149,-1.6798647912,-1.0411471233$ $\mathrm{H},-4.5308106969,-0.1560478981,-0.2162329207$ H,-4.1397236914,-1.69445774407,0.5722008769 H,-3.4535743266,-0.5004871249,-2.8710109035 $H,-1.7231754831,-0.2711343163,-2.5534963507$ $\mathrm{H},-2.9139580571,0.8255006242,-1.8265135001$ H,-2.5349420014,-4.8593001031,-0.7619904597 H,-3.5094524543,-3.5055212975,-1.3349474782 H,-3.8156844464,-4.1989147949,0.271432437
$\mathrm{H},-1.5492319507,-4.3265530585,1.656974831$ $\mathrm{H},-0.4721223548,-2.9188329918,1.4922223418$ $\mathrm{H},-0.3488744811,-4.2617194446,0.3452219707$ $\mathrm{H}, 4.9881177143,-0.7658332664,2.509008305$ H,5.2604670027,0.3471021269,1.166298558 $\mathrm{H}, 5.8659561968,-1.3201043804,1.0715227712$ H,3.9253292326,-3.0641463711,1.5341580097 $\mathrm{H}, 2.3293550636,-2.6298853628,0.8741611146$ $H, 2.8082855466,-2.0560289495,2.4817405292$ $\mathrm{H},-3.4902028661,2.2762146136,1.4320094805$ H,-2.8801337712,2.29245855539,3.1000750809 $\mathrm{H},-3.4131904814,0.7730765209,2.3670829847$ H, $-1.2794401184,-0.5347950988,2.3543111813$ $\mathrm{H},-0.8193554575,0.757751806,3.476834904$ $H, 0.2089897762,0.3898003312,2.080135496$ $\mathrm{H},-1.4877363369,2.8707598182,-1.9417376643$ H, $-0.4242998565,4.1662969549,-1.3692116986$ $\mathrm{H},-2.1799155295,4.4318097033,-1.4488961278$ $\mathrm{H},-2.7447864317,4.691762205,1.1163731011$ $\mathrm{H},-1.0287381825,5.0799717754,0.8956987982$ $\mathrm{H},-1.5102423979,3.9049705225,2.1212931041$ $H, 5.0670796949,-0.8050555637,-1.3102488467$ $\mathrm{H}, 5.7207676148,0.8268663848,-1.0500086303$ $\mathrm{H}, 4.7494826204,0.4777265945,-2.4882229645$ $H, 2.9527977035,2.109547199,-2.0682022956$ $\mathrm{H}, 3.8845032624,2.6910580908,-0.6847304337$ $\mathrm{H}, 2.2102149216,2.1425251592,-0.4544511605$

$H F=-1483.50979291 \quad \mathrm{NImag}=0$

12

Brutoformula: C3H11N6P1

0,1

N,0.385812851,-1.8895453644,1.2111990609

P,-1.1835901605,-1.3198679888,0.8123856141 $\mathrm{N},-1.927947742,-1.0363154096,2.320465433$ $\mathrm{N},-1.7492083741,-2.4375200755,-0.1306901008$ $\mathrm{N},-1.0637708566,0.272153985,0.3201162239$ $\mathrm{H},-2.6093473635,-2.2113688492,-0.6171405986$ C, $-0.086540336,0.7545008753,-0.3739042038$ $\mathrm{H}, 0.6143711107,-1.7752087922,2.1917240435$ $\mathrm{H}, 0.4732493232,-2.8628535034,0.9375392863$ $\mathrm{H},-2.3685037315,-0.1289797648,2.3970342182$ H,-2.544167397,-1.781494525,2.619726309 $\mathrm{N}, 1.0781084975,0.1566994864,-0.7850748622$ $\mathrm{N},-0.0695626611,2.0592716927,-0.8295975584$ $H, 1.3862217993,-0.6488646405,-0.248071866$ C, $1.9944704627,1.1451717896,-1.3466779763$ C,1.0113200297,2.2414801135,-1.797487034 $\mathrm{H},-0.9655655926,2.5047505298,-0.9558158198$ $\mathrm{H}, 1.4432903129,3.2412272755,-1.7368513856$ $\mathrm{H}, 0.6725041453,2.0609600123,-2.8256966138$ $\mathrm{H}, 2.5713564105,0.7343755379,-2.1764202777$ $\mathrm{H}, 2.688514468,1.5306971833,-0.5887224839$

$H F=-791.0073128 \mathrm{NImag}=0$

$12 \mathrm{H}+$ 
Brutoformula: C3H12N6P1(1+)

1,1

N, $-0.5395870443,-0.8153369318,3.2414260383$

P, $-0.4293244919,-0.896420041,1.5947034854$

N,-1.854531782,-1.5954687103,1.1741781422

$\mathrm{H},-0.5222673504,2.2850578481,-2.788135541$

$\mathrm{N},-0.2260869645,0.5252876405,0.8867825946$ $\mathrm{N}, 0.8492180499,-1.9077219149,1.1992035594$ $\mathrm{C}, 0.1201215853,0.7993143964,-0.3540155091$ $H,-1.2583137869,-0.217431309,3.6333378539$ $H, 0.3210891164,-0.7805796832,3.772109697$ $\mathrm{H},-2.2386432995,-1.4936345532,0.2465491188$ $\mathrm{H},-2.2937037925,-2.2893439604,1.7619901079$ $N, 0.2008006679,2.0631658462,-0.8108550558$ $\mathrm{N}, 0.4305242128,-0.0558220574,-1.3684598305$ $\mathrm{H},-0.1968378998,2.8206591448,-0.2762112588$ C, $0.419588294,2.1064991502,-2.2607272711$ C, $0.9611329887,0.685612597,-2.5262756401$ $H, 0.7440103058,-0.9914606217,-1.1489802738$ $H, 0.5968112221,0.2672488234,-3.4632872006$ $H, 2.0550237973,0.667505587,-2.5267404874$ $H, 1.1326546397,2.8833683641,-2.5331085344$ $H, 0.7683625739,-2.8869896635,1.4503199358$ $H, 1.7879436772,-1.5569255831,1.3565231273$

$H F=-791.4313748 \quad N I m a g=0$

\section{3}

Brutoformula: C6H15N8P1

0,1

$N,-1.5212213048,0.0359297433,-2.797729985$ $\mathrm{P},-0.6474765609,-0.0575616546,-1.349179691$ $\mathrm{N},-1.1730087177,1.1131080285,-0.284780645$ $\mathrm{N}, 0.9349304214,0.0747285622,-1.5649271295$ N,-1.2891493563,-1.4792118453,-0.7479871476 $H, 1.2772621906,-0.4571780093,-2.3603095693$ $H,-1.4393181992,0.9243054648,-3.2767111592$ $H,-2.4895978999,-0.2495370126,-2.7125348263$ C,- $0.4688690517,2.1449809198,0.0541999429$ C, $-0.562998925,-2.3272788723,-0.0998576777$ $\mathrm{N},-1.0978997085,-3.4173042775,0.5651296284$ $\mathrm{N}, 0.7958295409,-2.3736369372,0.0755819112$ $\mathrm{N}, 0.7467217691,2.5705989429,-0.4064801107$ $\mathrm{N},-0.8903812718,3.0424754838,1.0223874977$ C, $-0.0384660891,-4.3544242768,0.9332706306$ $\mathrm{H},-2.001339191,-3.7381281789,0.2527582007$ C,1.1709560086,-3.4034155935,1.0337011126 $H, 1.3380046159,-1.5472399371,-0.1663970926$ $\mathrm{H},-1.8842711978,3.1003301461,1.183427689$ C, $-0.0492445619,4.2372789901,0.9928138267$ C,1.258219692,3.6550102133,0.4213026512 $H, 1.3048529255,1.8507117512,-0.8814296409$ $\mathrm{H},-0.2547762932,-4.8563275841,1.8774115624$ $H, 2.1082805656,-3.8904788607,0.7595575515$ $H, 0.1276728526,-5.1127241535,0.1563489185$ $H, 1.2665200591,-2.9998864049,2.050338544$ $H,-0.4545329885,5.0088960194,0.3242449882$
$H, 1.819378145,4.3838586868,-0.1658719564$ $H, 1.9029301943,3.2818796563,1.2285590632$ $\mathrm{H}, 0.0807670928,4.6647288006,1.9882242385$

$H F=-1017.3065856 \quad N I m a g=0$

$13 \mathrm{H}+$

Brutoformula: C6H16N8P1(1+)

1,1

N,-1.194992691,-2.0827874729,-1.0944971569

P, $-0.8706179748,-1.1074208003,0.2434580797$ $\mathrm{N}, 0.514670116,-0.2888149681,-0.085595892$ $\mathrm{H}, 3.0346914087,-2.1026375963,-2.7659990076$ $\mathrm{N},-2.0696222517,-0.1232016159,0.6569839064$ $\mathrm{N},-0.8038077294,-2.2494223631,1.4467993043$ H, $-1.3192049726,-1.5780500224,-1.9666614784$ $\mathrm{H},-1.9618524641,-2.7335373512,-0.9545953666$ C, $1.6134775074,-0.8210525624,-0.57660235$ C, $-2.0726660086,1.1841109214,0.7877695472$ N,-3.2169511799, 1.8820120047,0.9855560079 $\mathrm{N},-1.0315818168,2.0507482211,0.7725996007$ $\mathrm{N}, 2.7683846023,-0.1225166636,-0.7028507027$ $\mathrm{N}, 1.8234476612,-2.0924939451,-1.0242086765$ C,-2.9333885367,3.2790371513,1.3281471916 $\mathrm{H},-4.0548732247,1.3961999191,1.2661086929$ C, $-1.5039106935,3.4398400614,0.7665845905$ $\mathrm{H},-0.142979443,1.7346899857,0.4034136505$ H,1.0227910587,-2.6248850107,-1.3430177748 C,3.1362517243,-2.2006206934,-1.68072892 C,3.8861548538,-0.9976710988,-1.0750654044 $\mathrm{H}, 2.8965278132,0.7227704789,-0.1682713396$ H, $-3.6452422545,3.957457045,0.8596576747$ H, $-0.8792795193,4.0763465747,1.392368535$ H, $-2.9567693451,3.4289432557,2.4124936806$ $\mathrm{H},-1.5182244032,3.8428976673,-0.2513642796$ H,3.6162092153,-3.1514115265,-1.4530091508 $H, 4.4637007831,-1.2885703291,-0.1919032913$ $\mathrm{H}, 4.54985886661,-0.5146083942,-1.791071328$ $\mathrm{H},-0.0889729211,-2.964037178,1.4263611688$ H,-1.0612281812,-1.9513136921,2.3771404905

$H F=-1017.7458883 \quad$ NImag $=0$

\section{4}

Brutoformula: C9H19N10P1

0,1

$\mathrm{N}, 0.0742739588,0.9482564156,1.2187702511$

$\mathrm{P}, 0.6540958264,0.3311718087,-0.2213270883$ $\mathrm{N}, 2.1097569572,-0.4029457961,0.1217948941$ $\mathrm{N}, 0.7888939272,1.4396307753,-1.377472578$ $\mathrm{N},-0.4513992201,-0.9177718366,-0.5513298349$ $H, 1.6882092816,1.3935407768,-1.8457782641$ C, $-0.3052163025,2.1737135379,1.3605570645$ C,-1.1945647354,-0.9137686302,-1.6119360613 C, $2.230203093,-1.5288786765,0.7388193829$ $\mathrm{N},-0.6108723509,2.7220783083,2.5989026919$ $\mathrm{N},-0.4922329212,3.1504371646,0.4167049103$ 
$\mathrm{H},-2.1273338864,-2.7202917469,-1.345226595$ $\mathrm{N},-1.173338996,-0.0779490853,-2.6899627422$ N,1.2666327106,-2.3630576568, 1.2474879124 N,3.4629760155,-2.1118353876,0.9927925857 $\mathrm{H}, 0.0005278577,2.9889187271,-0.4705236004$ C, $-0.7000857537,4.4428877813,1.0554786984$ C,- $-1.2737087667,4.0120318155,2.4192541884$ $\mathrm{H},-0.9107993223,2.0755261069,3.3124323844$ C, $-2.6628892486,-1.770888944,-3.2107234036$ $\mathrm{N},-2.2144547024,-1.8349402053,-1.8196287731$ $\mathrm{H},-0.6139350726,0.777846627,-2.5888620981$ C,- $-2.3125410312,-0.3113429773,-3.5627835385$ $\mathrm{H}, 0.3394403726,-2.2744728852,0.8369672647$ C, $1.851334841,-3.631994954,1.6637474558$ C,3.3063173362,-3.2114105235,1.942975744 H,4.2458784317,-1.4790761975,1.0586686615 H, $-1.02315136,4.7100444145,3.2197492428$ $\mathrm{H},-1.392748706,5.0688013238,0.4898918016$ $H, 0.2426482514,4.9913987931,1.1870947154$ $\mathrm{H},-2.3662599107,3.9098393393,2.3644937609$ $\mathrm{H},-2.108833685,-2.4677804131,-3.8540082879$ $\mathrm{H},-2.0501833844,-0.1877408342,-4.6150406352$ $\mathrm{H},-3.7302051456,-1.9794321693,-3.2989412931$ $\mathrm{H},-3.1512481597,0.3584327092,-3.328995282$ $H, 1.8112543299,-4.3826398979,0.8626683093$ $\mathrm{H}, 3.4184273054,-2.8749034043,2.9821983308$ $\mathrm{H}, 4.0187453244,-4.0156182868,1.7523442818$ H,1.35638688415,-4.0358159137,2.5487455428

$H F=-1243.5983048 \quad N I m a g=0$

\section{$14 \mathrm{H}+$}

Brutoformula: C9H20N10P1(1+) 1,1

$\mathrm{N},-0.2576124757,-0.0400455249,-0.8040565815$ P, $-0.4676942395,-0.8707085407,0.6016154552$ $\mathrm{N}, 0.6235704479,-2.0378926708,0.8715545841$ $\mathrm{H}, 3.9317600066,-3.5666285146,3.2999747107$ $\mathrm{N},-0.5281688335,0.197529605,1.8472065201$ $\mathrm{N},-1.8907167645,-1.7741182597,0.4301088728$ C, $-0.3159733855,-0.5774780649,-2.002536302$ C,- $-0.8892959853,1.4563269477,1.791320826$ C, $1.6299798887,-2.0222127779,1.7069318809$ $\mathrm{N},-0.6607910237,-1.838163499,-2.3655984031$ $\mathrm{N},-0.0240304857,0.1334662888,-3.1286792563$ $\mathrm{N},-1.2561366842,2.1984798082,0.712334354$ $\mathrm{N},-0.9392699446,2.2471021304,2.9012991053$ $\mathrm{N}, 2.4817025191,-3.075328735,1.8291709067$ $\mathrm{N}, 2.0231892849,-1.0480231181,2.5729536871$ $\mathrm{H}, 0.5624448774,0.9492284944,-3.0397554668$ C, $0.0529714773,-0.7505745721,-4.2978825325$ C, $-0.7883388668,-1.9520954251,-3.822811344$ H,-1.1944303993,-2.4041731612,-1.7177309134 C,- $-1.3547585722,3.6181004357,1.0718156664$ $\mathrm{H},-0.9447397007,1.868911336,-0.1966842236$ $\mathrm{H},-1.0320950435,1.8061340124,3.8037489778$ C, $-1.574114433,3.5340386214,2.5950280241$ $\mathrm{H}, 2.5198149305,-3.7638909574,1.0938288266$
C,3.631293909,-2.7308106133,2.6689496427 C,3.059393645,-1.5516906325,3.4815522633 H, 1.3355103979, $-0.3523153493,2.8379139506$ H, $-1.8343469308,-1.8539575478,-4.131546433$ $\mathrm{H}, 1.08832378,-1.0447172962,-4.4997185023$ $\mathrm{H},-0.3612213042,-0.2753282208,-5.1863816784$ $\mathrm{H},-0.400110876,-2.90400616,-4.1837403509$ $\mathrm{H},-0.4255636762,4.1467492649,0.8337478296$ $\mathrm{H},-1.0974327306,4.3530468302,3.1325064332$ $\mathrm{H},-2.1819505102,4.104406672,0.5557122294$ $\mathrm{H},-2.6406514302,3.5161566938,2.8437568209$ $\mathrm{H}, 4.4861082064,-2.4174136986,2.0597099188$ $\mathrm{H}, 2.621040453,-1.8962069291,4.4244510973$ $H, 3.8079872051,-0.7893360244,3.6953253478$ $\mathrm{H},-1.9881125848,-2.5226673209,1.1077059227$ $\mathrm{H},-2.7444339031,-1.2290613145,0.3709945596$

$H F=-1244.0538682 \quad \mathrm{NImag}=0$

15

Brutoformula: C3H9N6P1 0,1 $\mathrm{N}, 0.010201959,-1.1102307852,2.7779547527$ $\mathrm{P},-0.0571367473,0.1944048513,1.6842639775$ $\mathrm{N}, 1.5810382965,0.5427128164,1.2794604774$ $\mathrm{N},-0.5834641297,1.5818391083,2.1950515592$ $\mathrm{N},-0.7351478343,-0.6092223697,0.395139456$ $\mathrm{H},-1.5837780095,1.6425036237,2.3485184036$ $\mathrm{H},-0.1146265772,-0.8453711908,3.746418983$ $\mathrm{H},-0.5666833715,-1.8998320481,2.5201731861$ $H, 1.8609354094,1.4024143249,1.7415453824$ $\mathrm{H}, 2.2167747588,-0.2069577558,1.5290396731$ C, $-0.4755594885,-0.3171288695,-0.8459160003$ $\mathrm{N},-1.1861346732,-0.7883492423,-1.9255672002$ $\mathrm{N}, 0.5148180109,0.4550566197,-1.4048209409$ C, $-0.6324635843,-0.3312674862,-3.1212862985$ $\mathrm{H},-1.9955986199,-1.3753945686,-1.8150835139$ $H, 1.2465816445,0.8350789821,-0.8103149289$ $\mathrm{C}, 0.4287952603,0.4366838674,-2.7939054511$ $\mathrm{H},-1.0452710848,-0.5847737066,-4.0813559669$ $H, 1.1167187819,0.9778338301,-3.4193155492$

$H F=-789.7908459 \mathrm{~N} I m a g=0$

$15 \mathrm{H}+$

Brutoformula: C3H10N6P1(1+) 1,1 $\mathrm{N}, 1.456409115,-2.4192862387,1.0269235039$ $\mathrm{P}, 0.7059981541,-0.9596137134,1.0304049803$ $\mathrm{N}, 1.5940847383,0.4380639651,1.3327033389$ $\mathrm{H},-1.4003825686,3.2895239275,-1.5427661171$ $\mathrm{N}, 0.0622053168,-0.8659267529,-0.429017333$ $\mathrm{N},-0.1915488111,-1.0151172606,2.4235273889$ $\mathrm{H}, 1.9419698818,-2.7670687923,1.8406445195$ $\mathrm{H}, 1.6996331815,-2.8456114556,0.1448909872$ $\mathrm{H}, 2.0006878792,0.5322957324,2.2577116532$ $\mathrm{H}, 2.2676533863,0.6902152321,0.6171399595$ 
C, $-0.5037835532,0.1767965244,-1.0149422459$ $\mathrm{N},-1.1897732277,0.0976091145,-2.1828103194$ $\mathrm{N},-0.5465681259,1.4956979514,-0.6700597531$ C,- $-1.6546550618,1.3507157739,-2.570993395$ $\mathrm{H}_{-}-1.3291509034,-0.7756691641,-2.669006306$ $\mathrm{H},-0.0707845375,1.8692768361,0.1389605677$ C, $-1.2525782746,2.2273946458,-1.6271330253$ $\mathrm{H},-2.223506543,1.4988361373,-3.4718225714$ $\mathrm{H},-0.6232762826,-0.1710725564,2.7749461692$ $\mathrm{H},-0.7426337646,-1.8470599055,2.590697998$

$H F=-790.2191799 \mathrm{NImag}=0$

\section{6}

Brutoformula: $\mathrm{C} 6 \mathrm{H} 11 \mathrm{~N} 8 \mathrm{P} 1$

0,1

$\mathrm{N}, 0.6714135009,-0.6510306128,-0.3538727281$ P, $-0.0956198584,0.2048442502,0.8729771086$ $\mathrm{N},-0.1536461481,1.8031224468,0.4207973505$ $\mathrm{N}, 0.5891228785,-0.1985341954,2.2560057883$ $\mathrm{H}, 1.3893273268,0.7883660684,-1.560217576$ $\mathrm{H}, 0.217753071,0.2821973931,3.0684511569$ C, $1.4242603542,-1.6938864385,-0.1000624793$ $\mathrm{H}, 0.1475020582,4.3773475499,-0.1629615077$ C, $0.5496236621,2.3548481437,-0.5194757234$ $\mathrm{N}, 1.8741780882,-2.1922715196,1.0880592479$ $\mathrm{N}, 1.9606152705,-2.5238390432,-1.0590779667$ C. $1.425821642,3.9838327801,-1.8565631471$ $\mathrm{H}, 2.5073254478,2.5700343786,-3.1570838868$ $\mathrm{N}, 1.3359078543,1.8047841525,-1.5028861939$ $\mathrm{N}, 0.6226268476,3.7120725934,-0.7489429062$ H, 1.7145817782,-2.4547049252,-2.0318778987 $H, 1.6123266169,4.9851133289,-2.2017629304$ $\mathrm{H}, 3.1255022581,-3.8500682998,1.6863180491$ $\mathrm{H}, 1.6013163766,-1.6485883252,1.9347115741$ C,2.6674583175,-3.3098292787,0.8762709034 C, $1.8646441945,2.7948162119,-2.3240973893$ C. $2.720959801,-3.5295910757,-0.4571701277$ $\mathrm{H}, 3.2237828127,-4.2902808715,-1.0272980836$ $\mathrm{N},-1.7514245939,-0.1635388529,0.8160833613$ $\mathrm{H},-2.0888605395,-0.7639766791,1.5545225441$ $\mathrm{H},-2.3714847118,0.6060348552,0.6092779127$

$H F=-1014.8733265$ NImag=0

\section{$16 \mathrm{H}+$}

Brutoformula: $66 \mathrm{H} 12 \mathrm{~N} 8 \mathrm{P} 1(1+)$

1,1

$H,-0.511000807,-2.8493922926,-2.6100524409$ $\mathrm{P}, 0.380798522,0.3989943486,0.041489085$ $\mathrm{N},-0.0347101091,-0.8039549919,-0.9752307522$ $\mathrm{H}, 2.4736713243,-0.7866885172,-4.7563492022$ $\mathrm{N},-0.7828990128,1.4867850747,0.2998706479$ $\mathrm{N}, 1.6834631106,1.3301387988,-0.4836451203$ C,-4.3100902156,1.6271280061,0.3771494388 C,- $2.0810381401,1.2551172243,0.2283345079$ C, $0.5151552553,-1.0923400727,-2.1422595839$
C,- $-4.1431665745,0.3854372896,-0.1248223728$ C, $1.7391248822,-1.1300526631,-4.0496034467$ $\mathrm{N},-2.7686462824,0.1620472345,-0.2079074615$ N,-3.0370515634,2.1513242295,0.5916415836 $\mathrm{N}, 1.484865308,-0.4547961604,-2.8556502169$ $\mathrm{N}, 0.165649784,-2.1639497177,-2.9061437093$ $\mathrm{H}, 0.7912250589,-2.9693654737,-4.8206031103$ $\mathrm{H},-4.8651744456,-0.35422149,-0.4221818979$ $\mathrm{H}, 1.4857687883,2.3232335681,-0.5301148208$ C,0.9161310943,-2.1976368659,-4.0821127057 $\mathrm{H}, 2.5654686566,1.1408461857,-0.0216152693$ $\mathrm{H},-2.2881429305,-0.6415608787,-0.5936262932$ $\mathrm{H},-2.8137924316,3.0612092313,0.9644907548$ $\mathrm{N}, 0.932699568,-0.4006486787,1.3984436878$ H,-5.2043939157,2.1800913832,0.6032999038 $\mathrm{H}, 1.9333111752,0.3841857136,-2.5090780222$ $\mathrm{H}, 0.966782443,0.10628352,2.2744099933$ $\mathrm{H}, 0.6488241757,-1.3650326137,1.504037736$

$$
H F=-1015.3128822 \quad N I m a g=0
$$

\section{7}

Brutoformula: C9H13N10P1

\section{0,1}

N,1.2403066971,-1.108275643,-0.4450784643 $P, 0.1413546342,-0.4516570927,0.6475094258$ N,-0.3748327226, $1.0197994698,-0.0216520934$ $\mathrm{N}, 0.8628911989,-0.3579944645,2.0682529772$ $\mathrm{N},-1.2046810876,-1.430479916,0.632796189$ $\mathrm{H}, 0.2550583162,-0.0638247048,2.82581571$ C, $2.1937798708,-1.9044894045,-0.0210211774$ C, $-2.4180920639,-1.1150331226,0.321235416$ C, $0.3664447523,1.7614543046,-0.7897251875$ $\mathrm{N}, 2.626710613,-2.1607915696,1.2469505376$ $\mathrm{N}, 3.0141645607,-2.651473369,-0.836083299$ $\mathrm{N},-2.9831775182,0.0791867337,-0.0710196899$ $\mathrm{N},-3.4833977592,-1.996494227,0.3365175981$ $\mathrm{N}, 1.5174392188,1.4645834241,-1.4766760894$ $\mathrm{N}, 0.1038056735,3.0758276657,-1.1221583106$ $\mathrm{H}, 2.8574750617,-2.7363399787,-1.8260250259$ H, $-4.9731513352,0.7512499094,-0.6055306738$ $\mathrm{H}, 4.1777285711,-3.3827148323,2.124688633$ H,2.1496507046,-1.6083632686, 1.9965411058 C,3.6871325074,-3.0526476112,1.2255728301 H,-2.370621132,0.8851100879,-0.1790904356 $\mathrm{H},-3.368973584,-2.9596856741,0.6019871196$ H,4.6621046752,-4.0278044317,-0.5054471075 $\mathrm{H},-5.6088725494,-1.86744985551,-0.0835233152$ $\mathrm{H}, 1.8489083271,0.4992848077,-1.4535420187$ $\mathrm{H},-0.6327255361,3.6027990861,-0.6852672466$ C,- $-4.6641880507,-1.3554720413,-0.0362551554$ C, $-4.3487584861,-0.0669217951,-0.2917938996$ C,3.9319195624,-3.3715004096,-0.0664559942 C, $1.0777556776,3.5672631059,-1.9941094347$ C, $1.9468646226,2.5584053809,-2.2190272985$ H,1.06081955,4.5756691375,-2.3674723595 $H, 2.8302402858,2.526721484,-2.8323353067$ 
$H F=-1239.9462416 \quad N I m a g=0$

\section{$17 \mathrm{H}+$}

Brutoformula: C9H14N10P1(1+) 1,1 N,1.6227377863,0.1599475871, 0.470680947 $\mathrm{P}, 0.3059561262,0.7509829326,-0.2928987121$ N, $-0.3273873973,-0.2523485044,-1.435123234$ H,3.1857888822,-2.4771826659,-3.2391528385 $\mathrm{N},-0.8642201214,1.1544452593,0.7852049624$ $\mathrm{N}, 0.9295826426,2.0461765313,-1.1577399102$ C, $1.7499272331,-0.0571004854,1.7658222191$ C,-2.1620980353,1.1473310453,0.5403315267 C, $0.4437704201,-1.0043320994,-2.2029026874$ $\mathrm{N}, 0.9061568325,0.2111353211,2.7998887583$ $\mathrm{N}, 2.8490997602,-0.61919428666,2.3457697178$ $\mathrm{N},-2.8621365438,0.6046847921,-0.4937831102$ N,-3.1074028381,1.69849974466,1.3555635606 $\mathrm{N}, 1.7776178349,-1.2691234216,-2.1180766623$ $\mathrm{N}, 0.0123378326,-1.7198125993,-3.2800223046$ $\mathrm{H}, 3.662844981,-0.8973917892,1.821525861$ $\mathrm{H},-4.9587399894,0.4510590344,-1.0246099321$ $H, 0.96958884103,-0.0491859937,4.9512795908$ $\mathrm{H}, 0.0066420078,0.6457201604,2.6165647848$ C, $1.4764665445,-0.1750007788,4.011030913$ $\mathrm{H},-2.3692858561,0.0776552064,-1.2105753455$ $\mathrm{H},-2.8776710681,2.2266028649,2.1820714852$ $\mathrm{H}, 3.4481881141,-1.1024879369,4.3735121368$ H, $-5.2706396828,1.8552601949,1.3234241438$ $\mathrm{H}, 2.3369576942,-0.8969342715,-1.3577467397$ $\mathrm{H},-0.9416874174,-1.707568548,-3.6020645701$ C, $-4.3845221417,1.4945177613,0.8322946636$ C, $-4.2293551578,0.8076179933,-0.3190736814$ C, $2.6906780088,-0.6922008188,3.7298755297$ C, $1.0684214504,-2.4253287859,-3.8571778949$ C,2.1691841356,-2.1436198242,-3.1295425892 $\mathrm{H}, 0.9363529755,-3.050211171,-4.722332206$ $\mathrm{H}, 0.311360134,2.4983986624,-1.8195272315$ $H, 1.4954864422,2.708988886,-0.6424911509$

$H F=-1240.4047963 \quad \mathrm{NImag}=0$

\section{8}

Brutoformula: C5H15N6P1

0,1 $\mathrm{N}, 1.9662680693,0.7157988713,-2.035020919$ $\mathrm{P}, 2.0999331966,-0.3374101235,-0.7142359002$ N,3.4502552076,0.1276257745,0.2177231601 $\mathrm{N}, 2.1609217853,-1.7629265874,-1.3816228748$ $\mathrm{N}, 0.9318169413,0.18270852,0.3490591672$ $\mathrm{H}, 2.3379342301,-2.528821205,-0.7409891876$ $H, 2.4810154455,0.3851980727,-2.8421870974$ $\mathrm{H}, 2.191593109,1.6799475341,-1.8261120651$ $H, 3.2620364212,0.30211251,1.1945135781$ $\mathrm{H}, 4.2796264514,-0.4305397118,0.0695382261$ C, $-0.3591210428,0.1213187507,0.3398895934$ H,-1.0621661294,1.9187664203,3.0633985826
$\mathrm{N},-1.0931455797,0.7432948977,1.3439097923$ C, $-2.622045494,-0.131476609,-0.1447399513$ $H, 0.529247992,1.4656664613,2.4093303709$ C, $-0.4823282127,1.1153219592,2.6028045165$ C, $-2.4733233771,0.2826229053,1.3176834325$ $\mathrm{H},-2.9700436045,0.7075350566,-0.7650740108$ $\mathrm{H},-3.1656858914,1.0744295762,1.61181346$ $\mathrm{H},-3.3034161552,-0.9729780505,-0.2863423756$ $\mathrm{H},-2.6164754524,-0.5754723364,1.9929507051$ $\mathrm{H},-0.4345177832,0.2683306832,3.3030283761$ $\mathrm{N},-1.25479596,-0.5032138595,-0.5016267361$ C, $-0.99886333521,-0.9241589241,-1.8734577794$ $\mathrm{H},-0.0134813635,-1.3819512992,-1.9566103181$ $\mathrm{H},-1.0709111724,-0.0819994501,-2.5721410318$ $\mathrm{H},-1.7504833781,-1.6712846457,-2.1406491248$

$H F=-869.6364705 \quad \mathrm{Nlmag}=0$

\section{$18 \mathrm{H}+$}

Brutoformula: C5H16N6P1(1+) 1,1 $\mathrm{N}, 1.9860710809,-1.7274440232,-0.9747266047$ $P, 2.0978039598,-0.1841254983,-0.3585549307$ N,3.0359525441,0.9534068668,-1.1019137043 $\mathrm{H},-2.270338649,0.6594165234,-2.8452871665$ $\mathrm{N}, 0.6512503861,0.4558528886,-0.4069344236$ N. $3.0142697503,-0.492218598,0.9889415422$ $\mathrm{H}, 1.3243723126,-1.8884099203,-1.7216525396$ $\mathrm{H}, 2.82775228887,-2.2826485585,-1.0639534421$ $\mathrm{H}, 2.6037758932,1.5790026669,-1.7651876607$ $\mathrm{H}, 4.0228941666,0.7912157441,-1.2416554247$ C, $-0.5918767877,0.2695438229,-0.0231638648$ $\mathrm{H},-0.7716776716,-0.2325629396,3.2612581187$ $\mathrm{N},-1.0533405844,-0.0400564364,1.2137408883$ C, $-2.9030654357,0.4625344032,-0.1173048421$ $\mathrm{H}, 0.7062969229,0.0222383136,2.3334761762$ C, $-0.253678534,-0.4904648894,2.336581094$ C. $-2.506804497,-0.2467144791,1.1841427736$ $\mathrm{H},-3.2267916067,1.4950703032,0.0621942797$ $\mathrm{H},-2.9777792438,0.1878310814,2.0663112846$ $\mathrm{H},-3.6877641547,-0.0601401971,-0.6646922051$ $\mathrm{H},-2.7369773452,-1.3181754211,1.1531875347$ H, $-0.0932023736,-1.5751684623,2.3195013314$ $\mathrm{N},-1.6420611231,0.4526377953,-0.8656077651$ C, $-1.5456182822,1.1041303376,-2.1614118674$ $\mathrm{H},-0.5441138781,0.961648776,-2.5604114744$ $\mathrm{H},-1.7467121486,2.1784715208,-2.0796010603$ $H, 3.4429357888,0.2778721359,1.4826612402$ $\mathrm{H}, 2.8384272213,-1.3127437575,1.5500627113$

$H F=-870.0702187 \quad N I m a g=0$

19

Brutoformula: $\mathrm{C} 10 \mathrm{H} 23 \mathrm{~N} 8 \mathrm{P} 1$ 0,1 N,-0.3527193082,0.013419253,-1.1678514885 P,-1.037192643,-0.3615117192,0.2977392054 
$\mathrm{H}, 0.519381233,1.9742978488,3.0120332848$ $\mathrm{N},-2.4771202032,-0.9958947834,0.1271200311$ $\mathrm{N},-0.8005282788,1.0179394588,1.1971563823$ $\mathrm{H},-2.9313357185,-1.1995495243,1.0136790487$ C, $-0.0695080961,-0.564000237,-2.2777135162$ C, $-1.3747748408,2.1658409789,1.2349628704$ $\mathrm{H},-0.759762996,2.5119981176,4.1204664688$ $\mathrm{N},-0.4243462604,-1.794447689,-2.8096392902$ $\mathrm{N}, 0.7711582452,0.0616320331,-3.2017526834$ $\mathrm{N},-2.4618206706,2.6892715769,0.5549054261$ $\mathrm{N},-0.9181279226,3.1560363068,2.106487437$ $\mathrm{H},-3.9778558122,2.6009169418,-0.8562085601$ $\mathrm{H},-2.0593728369,-2.1914547708,-1.5392268735$ C, $1.6678064419,1.1193154032,-2.7823673333$ C, $1.2198582013,-0.8954028298,-4.2003101662$ C, $0.0872465985,-1.9191366422,-4.1725264823$ C, $-1.6587571929,-2.507798141,-2.5046303242$ C, $-2.5965506648,4.1131086993,0.8464754823$ C,-2.969612572,2.2015663222,-0.719199856 C,- $-0.1284674075,2.8094434319,3.2699707922$ C,- $-1.8924301767,4.2320634164,2.1963803213$ $\mathrm{H},-3.0321808906,1.1135904893,-0.7091476804$ $\mathrm{H},-1.4635996941,-3.5844922271,-2.4924590978$ $\mathrm{H}, 2.6170763757,0.7208447636,-2.3934882896$ $H,-2.4134247103,-2.3033845281,-3.2775053696$ $\mathrm{H},-0.6994371795,-1.6646492061,-4.8984074608$ $H, 2.1790460674,-1.3506593549,-3.9059078949$ $H, 1.3486821675,-0.4276561366,-5.1793779711$ $H, 0.4241998452,-2.9383564395,-4.3761267667$ $\mathrm{H},-2.0920018418,4.7194721652,0.0787639503$ H, $-1.408867052,5.200664801,2.3434449829$ $\mathrm{H},-3.6478954487,4.4072870614,0.8833693002$ $\mathrm{H},-2.5953284011,4.0633648491,3.0278532342$ H,1.1822013379,1.6901638784,-1.9935034385 H,-2.3436110913,2.5298406632,-1.5591579301 $\mathrm{H}, 1.8857240771,1.7742202255,-3.6299819731$ $\mathrm{N}, 0.0176929674,-1.3779837715,1.1670046524$ $\mathrm{H}, 0.480849211,3.6666653234,3.5676679213$ $\mathrm{H}, 0.0796824286,-2.3177157376,0.796585005$ $\mathrm{H}, 0.9314876353,-0.9905154576,1.3684181245$

$H F=-1174.5551341 \quad \mathrm{NImag}=0$

\section{$19 \mathrm{H}+$}

Brutoformula: C10H24N8P1(1+) 1,1 $\mathrm{N},-0.7324194204,0.0466261131,-1.4588613663$ P,-1.0979072661, $-0.1757246514,0.0938091994$ $H,-0.9165358781,2.0737057469,4.168603936$ $\mathrm{H},-1.9656460705,-3.0495207992,-3.0153997014$ $\mathrm{N},-0.8351902829,1.133089575,0.9845941263$ $\mathrm{N},-2.6537334814,-0.8124940188,0.1453371632$ C, $-0.1569276083,-0.6352511548,-2.4191098193$ C, $-1.3795528322,2.29670736,1.2126855561$ H,-2.2254933999, 1.8745387728,-1.2713192958 $\mathrm{N},-0.1816966773,-1.9828697562,-2.6644433123$ $\mathrm{N}, 0.5884324839,-0.0196858747,-3.3761774101$ $\mathrm{N},-2.3582900614,2.9644916742,0.5236603029$
$\mathrm{N},-1.0053253336,3.0468604755,2.2899090815$ $\mathrm{H},-3.7703212731,2.7250672955,-1.0131118376$ H,1.0628577111,1.8331195032,-4.2189195338 C, $1.1048310911,1.3318796841,-3.2498509391$ C, $1.2662217476,-0.9972340545,-4.2265962336$ C, $0.4611728009,-2.2723898268,-3.9545239094$ C,-1.2273115607,-2.8942044752,-2.2189517425 C,-2.563828102,4.2987982806,1.1021069797 C, $-2.6865789571,2.7786527099,-0.8812870551$ C,- $-0.2538512813,2.5100262376,3.4109209053$ C,- $-1.9260444051,4.1648350668,2.4874422985$ H,- $-0.7890191272,-3.8621505566,-1.9651563905$ $\mathrm{H}, 0.4917290093,1.8740903179,-2.5340560245$ $\mathrm{H},-3.0480645461,-0.9655668072,1.0662814758$ $\mathrm{H},-1.7463886793,-2.4970197363,-1.3503089685$ $\mathrm{H},-0.3080482869,-2.437211464,-4.7191244357$ H,2.3140157124,-1.1004378992,-3.9179693364 $H, 1.2434605753,-0.6961737322,-5.2750328552$ $H, 1.0835298939,-3.1659601866,-3.8919952732$ $\mathrm{H},-2.0504603725,5.0510451186,0.4898689449$ $H,-1.3959727113,5.0653676271,2.8006809126$ $\mathrm{H},-3.624630686,4.550308646,1.1426157898$ $H,-2.6694581131,3.9137013685,3.2551721548$ $\mathrm{H}, 2.1440216393,1.3250166367,-2.9000881559$ $\mathrm{H},-3.3278045038,-0.4247074544,-0.5019100653$ $\mathrm{H},-2.3105936035,3.6238427677,-1.4704974225$ $\mathrm{N},-0.2260287306,-1.3277944925,0.9225412381$ $\mathrm{H}, 0.3259005352,3.312575328,3.8698935302$ $\mathrm{H}, 0.4253330251,1.7423109458,3.0482258816$ $\mathrm{H},-0.1170074912,-2.2499986446,0.5250567481$ $\mathrm{H}, 0.583495016,-0.9997598714,1.4292748131$

$H F=-1175.0061812 \quad \mathrm{NImag}=0$

\section{0}

Brutoformula: C15H31 N10P1

0,1

N, $-0.102725779,0.073844786,-1.2544013431$ P, $-0.9457762368,-0.3496747597,0.1280373409$ $\mathrm{N},-0.1367803131,-1.5544670431,0.9658811339$ $\mathrm{N},-2.4162278547,-0.7586939994,-0.2860461169$ $\mathrm{N},-0.7249289618,0.9670660843,1.1483617806$ $\mathrm{H},-2.9788544013,-1.0804944368,0.4968779536$ C, $0.005983936,-0.4941883109,-2.4043795125$ C,-1.2967601588,2.11287777555,1.2409535176 C, $1.0197228805,-1.7374038187,1.4859569926$ $\mathrm{N},-0.2009967746,-1.7897081537,-2.8351367687$ $\mathrm{N}, 0.45936065,0.2330910537,-3.5091224629$ $\mathrm{N},-2.2613318283,2.7508592735,0.4783950822$ $\mathrm{N},-0.9635993188,2.982697923,2.2896410305$ $\mathrm{N}, 1.2452605707,-2.8131972025,2.3512182995$ C,2.4227663547, $0.2819140782,0.8786228219$ C, $1.1895882703,1.469311966,-3.3382435816$ C, $0.7987160774,-0.6637992986,-4.6007911928$ C, $-0.093170918,-1.864580181,-4.2876816923$ C, $-0.9280557739,-2.8359053399,-2.132740464$ C,-2.4217127474,4.1318856051,0.9202116723 C, $-2.5848076943,2.4392874198,-0.906261356$ 
C,- $-0.3993976644,2.4625407089,3.517393802$ C, $-1.927421649,4.0688014024,2.3628648952$ C, $0.339558059,-3.9415720624,2.3800573759$ C,2.6704165937,-3.0285817249,2.5311716411 C,3.2202069967,-1.6281457954,2.2665839783 $\mathrm{N}, 2.2348166009,-1.0814596813,1.3409072239$ $\mathrm{H},-1.0803375248,-1.7645523116,-4.7626922693$ $H, 1.8652657207,-0.9415682257,-4.5739407302$ $H, 0.5833792662,-0.2125824886,-5.5722947854$ $H, 0.34543882225,-2.8160412181,-4.597246898$ $\mathrm{H},-1.8013610391,4.8115745973,0.315421198$ H,-1.462012018,4.9992420845,2.6977205877 $H,-3.4632673354,4.4511391243,0.8369475252$ $\mathrm{H},-2.750114263,3.8236192858,3.0541531137$ H,3.0610961772,-3.7544083804,1.7991319669 $\mathrm{H}, 3.2618408146,-1.0337685099,3.1923065301$ $H, 4.216756212,-1.6363286117,1.8180122171$ $\mathrm{H}, 2.8984961013,-3.3950590905,3.5350026749$ $\mathrm{H}, 0.2094127145,3.2314361983,4.0010650971$ $\mathrm{H}, 0.2212246216,1.6029242007,3.2722909773$ $\mathrm{H},-1.1809159656,2.1387250922,4.2217438698$ $H,-2.6670373625,1.3600311602,-1.0361840577$ $\mathrm{H},-1.8378900246,2.8501767863,-1.5989707457$ $\mathrm{H},-3.5550469005,2.8888642218,-1.1342940756$ $H, 1.6960103205,0.5259476037,0.1087399608$ H, 3.4274494149,0.3646664316,0.4520851676 $\mathrm{H}, 2.3277279431,1.0066731149,1.6971013165$ $\mathrm{H}, 0.5848047988,-4.6854736384,1.6066812737$ $\mathrm{H},-0.6705101268,-3.5769534377,2.2030216522$ $H, 0.3883700921,-4.4266070368,3.358544767$ $\mathrm{H}, 0.7985574881,1.980864135,-2.4606657825$ $H, 1.056320818,2.1017255428,-4.2200776029$ $H, 2.2669095317,1.2952465442,-3.192113765$ $\mathrm{H},-0.6928677374,-2.8128438906,-1.071627954$ $H,-0.6080469211,-3.7973210214,-2.5460216092$ $\mathrm{H},-2.011264789,-2.7250032741,-2.2367574779$

$H F=-1479.4688653 \quad$ NImag=0

\section{$20 \mathrm{H}+$}

Brutoformula: C15H32N10P1(1+)

1,1

$\mathrm{N},-0.2797878713,0.1177269393,-1.4413393993$ $\mathrm{P},-0.7859587728,-0.23766877986,0.0658115948$ $\mathrm{N},-0.0832566331,-1.4938445296,0.8088293846$ $\mathrm{H},-1.9641264506,-2.8395843546,-2.4308812683$ $\mathrm{N},-0.6159213111,1.0767901933,1.0069570401$ $\mathrm{N},-2.3828112411,-0.7742591425,-0.0606279828$ C, $-0.0395266692,-0.533045939,-2.5504707173$ C,-1.2733704835,2.1711978207,1.2498766993 C, $1.0487077862,-1.7110518483,1.4180654276$ $\mathrm{N},-0.1337408184,-1.8616884377,-2.8664787448$ $N, 0.4101448006,0.1458259006,-3.6565581989$ N, $-2.2110726043,2.8356667667,0.491134822$ $\mathrm{N},-1.0976357732,2.8584181974,2.4240772266$ $\mathrm{N}, 1.1735257223,-2.7400889566,2.3165132755$ C,2.5447156967,0.1791108105,0.6628003603 C, $0.9850691489,1.4763684573,-3.5919063299$
C, $0.8385083293,-0.7847725081,-4.6967796685$ C, $0.0806433426,-2.0531869914,-4.3058003346$ C, $-0.9038699619,-2.8736027204,-2.1561676557$ C,-2.5745560335,4.1040750599,1.1344552932 C, $-2.2902040084,2.7831805515,-0.9609166588$ C, $-0.4924067514,2.2580989661,3.5985439525$ C,-2.1191570163,3.8902359507,2.5790795056 C, $0.1970956977,-3.8052782932,2.4416789173$ C, $2.5778505045,-2.9775362784,2.6374320313$ C,3.2058047638,-1.6262081759,2.2875338556 $\mathrm{N}, 2.2662762547,-1.098312168,1.2947465268$ $\mathrm{H},-0.8842032028,-2.1244975333,-4.8245519724$ $H, 1.9266292009,-0.9321049469,-4.6563675346$ $H, 0.5753790708,-0.4190608225,-5.6904804408$ $\mathrm{H}, 0.6456050758,-2.9668230491,-4.4953462754$ H, $-2.0309765828,4.9305409684,0.6581880513$ $\mathrm{H},-1.7094874993,4.793669197,3.033825321$ H,-3.6446857619,4.298416126,1.0471188041 $\mathrm{H},-2.9379995851,3.5234489948,3.2127439096$ $H, 2.9859533092,-3.7869959657,2.0164776154$ $H, 3.2542925908,-0.9626399334,3.1608803567$ H,4.2073984759,-1.7167747771,1.8643881667 $\mathrm{H}, 2.7042079718,-3.2475726222,3.6868324795$ $\mathrm{H}, 0.0380365988,3.0239962588,4.167960607$ $\mathrm{H}, 0.2105049374,1.4932084907,3.2768215293$ H,-1.2481043736,1.7967607514,4.2475026874 $\mathrm{H},-1.7706964764,1.9078035724,-1.3436372694$ $\mathrm{H},-1.8193663051,3.6720189479,-1.4004775667$ $\mathrm{H},-3.3359230796,2.7594628372,-1.2786737812$ $H, 1.8769222812,0.3424721034,-0.1795854195$ $\mathrm{H}, 3.5715129452,0.1620354741,0.290042626$ $\mathrm{H}, 2.4357247754,1.0142897501,1.3628532722$ $H, 0.4169780196,-4.637953419,1.7609626516$ H, $-0.7884706585,-3.4096183652,2.2073213168$ $\mathrm{H}, 0.2001514258,-4.1807761041,3.4667714622$ $H, 0.5655242505,2.0007395259,-2.7368754441$ $H, 0.7462698007,2.0229174813,-4.5066450489$ $\mathrm{H}, 2.0768613472,1.4352643397,-3.4837739061$ $\mathrm{H},-0.80983251,-2.7463394183,-1.0821023884$ $\mathrm{H},-0.5017650256,-3.8523062721,-2.4256601534$ $\mathrm{H},-2.7735285042,-1.1426426571,0.798527701$ $\mathrm{H},-3.0264318242,-0.1375928439,-0.5136495458$

$H F=-1479.9396202 \quad N I m a g=0$

\section{1}

Brutoformula: C5H13N10P1

0,1

$\mathrm{N}, 1.0810180367,0.1577982779,0.1564817019$ $\mathrm{P},-0.5827727582,-0.2133532557,0.2827363326$ N,-1.2350980649,0.8335818929,-0.8445455875 $\mathrm{N},-1.2218284469,-0.0150559886,1.7409845814$ $\mathrm{N},-0.7537414181,-1.7523110717,-0.2989671928$ $\mathrm{H},-1.319435711,-0.8890014625,2.2482932454$ C, $1.7301751072,0.8253735704,1.060715639$ C, $-2.2825508512,1.5740511385,-0.662976042$ C, $-0.0171918448,-2.2706222049,-1.235002772$ $\mathrm{N}, 3.0151886106,1.2678808364,0.7784086082$ 
$\mathrm{N}, 1.2829530807,1.1525627862,2.309158312$ $\mathrm{N}, 1.1190640753,-1.8090993057,-1.8540012686$ $\mathrm{N},-0.2470603777,-3.4966238539,-1.8193914531$ $\mathrm{N},-2.6405489348,2.4612910337,-1.6701081244$ $\mathrm{N},-3.0999813379,1.5874376183,0.4329115861$ $\mathrm{H},-1.039605862,-4.0636158495,-1.5697216466$ C, $0.7364495396,-3.7861093853,-2.7642243101$ $\mathrm{H}, 1.5483780279,-0.9540690702,-1.5018383142$ C,1.5879961909,-2.736963824,-2.7776040713 $\mathrm{H},-3.5991648725,2.4427619882,0.6242100264$ $\mathrm{H},-2.7066414178,1.0690660149,1.2326800398$ $\mathrm{H},-2.1391089262,2.2939743294,-2.5302777349$ $\mathrm{H},-3.6304649529,2.620598051,-1.7936045714$ $H, 1.664575983,1.9798867382,2.7406167733$ $H, 0.2911311008,0.9196989619,2.4702980009$ $\mathrm{H}, 3.3894197859,0.905885752,-0.0852924948$ $H, 3.6699477196,1.2670279765,1.5475916122$ $\mathrm{H}, 0.7356456866,-4.6959165268,-3.3376787095$ $\mathrm{H}, 2.4715005932,-2.5670958434,-3.3676128156$

$H F=-1087.5386347 \quad N I m a g=0$

\section{$21 \mathrm{H}+$}

Brutoformula: C5H14N10P1(1+) 1,1 $\mathrm{N}, 0.3794839391,1.1646187611,0.5875606833$ $P,-0.4606244129,-0.253268351,0.5914724731$ $\mathrm{N},-2.0404251554,-0.0779562615,0.2805135584$ $H, 4.5050872432,0.0065295564,-1.3836337739$ $\mathrm{N}, 0.2703421051,-1.2983650739,-0.4302394776$ $\mathrm{N},-0.4895114442,-0.7967995916,2.2024222695$ C, $0.1518935242,2.1939015621,1.387860265$ C, $-2.7491396171,-0.4773817022,-0.7495953913$ C, $1.5245212192,-1.2481496933,-0.8430241547$ $\mathrm{N},-0.5482681074,2.1423446431,2.5383257853$ $\mathrm{N}, 0.6914680664,3.3874814637,1.0443945401$ $\mathrm{N}, 2.4538177661,-0.2598264111,-0.7339888702$ $\mathrm{N}, 2.149902757,-2.2475709403,-1.5277689011$ $\mathrm{N},-4.0061270481,0.0176962325,-0.8821029398$ $\mathrm{N},-2.3359419602,-1.3611240515,-1.6865141555$ $\mathrm{H}, 1.7118668363,-3.1339342481,-1.7226827512$ C,3.4565305569,-1.8790792623,-1.8471590051 $\mathrm{H}, 2.1960837377,0.6264414746,-0.3083530926$ C,3.6431339615,-0.6362154619,-1.3544578128 $H_{-}-2.8515270051,-1.4939252756,-2.541188876$ $\mathrm{H},-1.3732463854,-1.67679477744,-1.6288331814$ $\mathrm{H},-4.6863408026,-0.4329473989,-1.4727918301$ $\mathrm{H},-4.3485240825,0.5923710362,-0.1291222781$ $\mathrm{H}, 0.6043789455,4.2080676114,1.6207207185$ $H, 1.0683163165,3.4896896386,0.1172427916$ $\mathrm{H},-0.7529250984,2.9674429697,3.0775001286$ $\mathrm{H},-0.8559824694,1.2377860154,2.875961439$ $\mathrm{H}, 4.1215711965,-2.5304849867,-2.3856731086$ H,-1.1880403114,-1.5104831015,2.3831188403 $H, 0.41164424,-1.0847759801,2.5710425704$

$H F=-1087.9857948 \quad \mathrm{NImag}=0$

\section{2}

Brutoformula: C5H15N10P1

0,1

N, $-0.073650852,0.7014785523,-1.2315852166$

P, $-0.1365335634,0.8901273117,0.4583932704$

$\mathrm{N},-1.5573939928,0.0991113285,0.8354424238$

$\mathrm{N},-0.109952874,2.4072058518,0.98157049$

$\mathrm{N}, 1.120936477,-0.01011903,1.0696840619$ $\mathrm{H}, 0.7923209206,2.6730564281,1.362919627$

C, $-0.2470058679,1.6780302005,-2.068365618$

C,-2.4912776959,0.560745394,1.6054171627

C, $1.5529387007,-1.1195284196,0.5717133785$

N, $-0.3860140631,1.3865359415,-3.4182318928$

N, $-0.3063018342,3.0096863442,-1.7689549515$ N,2.6169906926,-1.8156574305,1.120262234

$\mathrm{N}, 1.1187969465,-1.8224229741,-0.523399518$

$\mathrm{N},-2.6193271436,1.8445757182,2.0603765336$

$\mathrm{N},-3.4933511441,-0.3075984715,2.0163342472$

$\mathrm{H}, 0.6168518174,-1.2811240661,-1.2240164101$

C, $2.0483938147,-2.8998557999,-0.843852226$

$\mathrm{H}, 2.7872284932,-1.6689714661,2.1036029301$

C,2.69969888863,-3.1496919207,0.5293883927

H, $-3.4737559792,-1.1868146939,1.5206161129$

$\mathrm{H},-4.416411893,0.0894042739,2.1197337488$

$\mathrm{H},-3.1096465371,1.9735472392,2.9326716845$

H,- $-1.7725047894,2.4116615149,1.8988102665$

$\mathrm{H},-0.8395445326,3.60297494,-2.3854808201$

$\mathrm{H},-0.323086611,3.2064204575,-0.7568544672$

$\mathrm{H},-0.1986309468,0.4215892787,-3.6442966598$

$H, 0.012775408,2.0513535031,-4.0657660859$

$\mathrm{H}, 2.80060053,-2.5838052611,-1.5790621118$

$\mathrm{H}, 2.1236483446,-3.8881678091,1.1024729616$

$H, 3.7322217902,-3.4925552419,0.4471714589$

$H, 1.5309875003,-3.7811916923,-1.2267150062$

$H F=-1088.754926 \quad N I m a g=0$

\section{$22 \mathrm{H}+$}

Brutoformula: $\mathrm{C} 5 \mathrm{H} 16 \mathrm{~N} 10 \mathrm{P} 1(1+)$

1,1

N,- $0.3313954278,0.5162090097,1.0102266234$

$\mathrm{P},-0.0261334738,-1.0040173043,0.4687582866$

$\mathrm{N},-1.3339977142,-1.9523838146,0.5599356523$

$\mathrm{H}, 2.5659225493,3.4344081474,-0.645279891$

$\mathrm{N}, 0.6275855226,-0.9141279378,-1.0353786397$ N,1.0814755597,-1.8409484122,1.4448825104 C, $0.2825628169,1.6206591084,0.6570450882$ C, $-2.5933741882,-1.6446167509,0.7708533658$ C, $1.1020123624,-1.9325346651,-1.7323625888$ $\mathrm{N},-0.0224936159,2.8296870342,1.2043914853$ $\mathrm{N}, 1.2722451512,1.7939155417,-0.2586598823$ N,1.2703207399,-1.7596920254,-3.0637932348 $\mathrm{N}, 1.4592091414,-3.1277454631,-1.2183186641$ N,-3.5220451415,-2.6106492424,0.5554337499 N,-3.0436142195,-0.4450743235,1.200556455 H, 1.7119498788,-3.9064774002,-1.8041058595 H,1.4302713952,-3.2517315645,-0.2136877377 
$H, 1.7488350538,-2.4277419971,-3.6447779513$ $\mathrm{H}, 0.9261135555,-0.9116731685,-3.4811967998$ $\mathrm{H},-2.3580531637,0.2939735965,1.3179787968$ $\mathrm{H},-4.0249043441,-0.22023996667,1.1937563666$ $\mathrm{H},-4.4520099164,-2.5385624829,0.9354888712$ H, $-3.1775149548,-3.5297900342,0.3301317894$ H, $1.3634480755,1.0805623934,-0.9756627991$ C, $1.5069371882,3.2229143263,-0.5012946928$ $\mathrm{H},-0.4788121363,2.8557774531,2.103525792$ C, $0.9479288214,3.8498955196,0.7913920511$ $H, 0.4668512666,4.8114613119,0.6161795024$ $\mathrm{H}, 0.9515037916,3.5653735866,-1.3807503459$ $H, 1.731999381,3.9746667344,1.5457391924$ $H, 1.9594475531,-1.3581183357,1.6081638017$ $\mathrm{H}, 0.6926501462,-2.178460324,2.3192199491$

$H F=-1089.2027097 \quad N I m a g=0$

\section{3}

Brutoformula: C3H17N13P2

0,1

$\mathrm{N}, 0.9492624083,2.7547294357,-1.8626052795$ $\mathrm{P}, 0.9565684194,2.2079959446,-0.2299027416$ N, $-0.5382919186,2.7999742595,0.3513598419$ $\mathrm{N}, 2.2814789238,2.7948310108,0.3854859607$ $\mathrm{N}, 0.7803355228,0.5821807214,-0.3108903061$ $P,-0.2719792925,-0.5874925994,-0.1210608926$ $H, 2.5214613446,2.4207820093,1.2985421411$ $\mathrm{N},-1.5923331853,-0.0761442645,0.7640884183$ $\mathrm{N}, 0.3906652464,-1.9091079985,0.6765577232$ $\mathrm{N},-0.9069640601,-1.2646842796,-1.4922082033$ C, $-0.7937192521,-0.8776741366,-2.7226720532$ C, $1.6593024642,-2.1228531898,0.8715584768$ C,-2.3827105638,-0.7980599122,1.491055071 $H, 1.8460013577,3.1765633169,-2.0813905435$ $\mathrm{H}, 0.2106642295,3.4303436673,-2.0209058531$ H,-1.1625433242,2.0766382647,0.7014219136 H, $-0.4303008567,3.5652901071,1.0043694935$ $\mathrm{N}, 2.0515204602,-3.356983976,1.3603624977$ $\mathrm{N}, 2.6739097161,-1.2481577707,0.6482448564$ $\mathrm{N},-2.2891665453,-2.1477721998,1.697883048$ $\mathrm{N},-3.4323362783,-0.1791535621,2.1466845795$ N, $-1.5451069032,-1.5507111479,-3.6756365208$ $\mathrm{N},-0.0164033907,0.1209743269,-3.2282071194$ $\mathrm{H}, 1.2867308775,-3.9477050843,1.647596594$ $\mathrm{H}, 2.8541195747,-3.37606886671,1.9724817648$ $H, 3.6035103973,-1.6063314344,0.5005633576$ $\mathrm{H}, 2.404491059,-0.3680655193,0.2015036096$ H, $-3.6248243942,0.7520163769,1.8092207806$ $H,-4.25713988875,-0.7353027654,2.3182141874$ $\mathrm{H},-2.7136328,-2.5192893157,2.534215477$ $H_{-}-1.3882105338,-2.5456782187,1.4330389085$ $\mathrm{H}, 0.4258948295,0.7932412086,-2.6027345267$ $H,-0.2740301246,0.4942010364,-4.1285494583$ $\mathrm{H},-1.1436208615,-1.6367175349,-4.5982306265$ $\mathrm{H},-1.9598590175,-2.3991321353,-3.3201740066$

$H F=-1519.4767584 \quad N I m a g=0$

\section{$23 \mathrm{H}+$}

Brutoformula: C3H18N13P2(1+) 1,1 $\mathrm{N}, 1.8710519337,3.2250522913,-0.8775202475$ $\mathrm{P}, 1.0214341865,2.4958352751,0.3586239852$ N. $-0.5187704274,3.0117024722,0.007426037$ $H, 0.9138744137,-0.4492401999,-4.002039353$ $\mathrm{N}, 1.0148464544,0.9326685794,0.6304870314$ $\mathrm{P}, 0.1139484303,-0.2577671947,-0.0255258554$ $\mathrm{N}, 1.8168209123,3.1511024138,1.664839199$ $\mathrm{N},-1.49396286007,-0.0533453945,0.3588498885$ $\mathrm{N}, 0.6217876215,-1.7162370219,0.5578956795$ $\mathrm{N}, 0.3079656451,-0.2263609906,-1.6521238192$ C, $-0.5529245887,-0.3769642583,-2.6184188431$ C, $1.8616580589,-2.0656718693,0.8261255091$ C,-2.1875623815,-0.6468916022, 1.3048671106 $H, 2.8801933673,3.1738122228,-0.8290069991$ $\mathrm{H}, 1.5182941422,3.0723772344,-1.8132765233$ $\mathrm{H},-1.2863190186,2.4341694945,0.3252228126$ $\mathrm{H},-0.72670188,3.9893796182,-0.1353053742$ $\mathrm{N}, 2.1395187776,-3.3905035218,0.9484676083$ $\mathrm{N}, 2.8876463863,-1.2083989615,1.0156129475$ $\mathrm{N},-1.7970430838,-1.7355438477,1.9986388327$ $\mathrm{N},-3.4139021645,-0.1335958063,1.6216567922$ $\mathrm{N},-0.0851922041,-0.3586498815,-3.9036153847$ $\mathrm{N},-1.897005049,-0.536450165,-2.4737502953$ $H, 1.3881900507,-4.0413659846,0.7920292872$ H,2.9675423973,-3.7195081311,1.4171992393 $\mathrm{H}, 3.8425679544,-1.5250301422,1.0392271322$ $\mathrm{H}, 2.6759539127,-0.2156831965,0.9735903094$ $\mathrm{H},-3.7591532206,0.6116448832,1.0396282589$ $\mathrm{H},-4.1045121644,-0.7075122106,2.0793941106$ $\mathrm{H},-2.3040397898,-2.0581660257,2.8058055439$ H, $-0.8921682388,-2.1336801097,1.7570918186$ $\mathrm{H},-2.2647011587,-0.3385043603,-1.5493715151$ $H,-2.5044458343,-0.3891608698,-3.264336781$ $\mathrm{H},-0.6435050274,-0.752205384,-4.6450843069$ $\mathrm{H}, 1.9378701395,4.1533977199,1.7132253564$ H,1.6593676147,2.7120044848,2.5607865916

$H F=-1519.9366362 \quad \mathrm{NImag}=0$

\section{4}

Brutoformula: C5H21N17P2

0,1

$\mathrm{N},-3.5629472448,-0.0200404217,-0.6671001543$

P,-2.1526580019,0.0163563586,0.2407841823

$\mathrm{N},-1.9756438096,-1.2179821319,1.2931180461$

$\mathrm{N},-2.2654465859,1.5442366388,0.9353188125$

$\mathrm{N},-0.9043512562,-0.0630533521,-0.7694885062$ C,-4.0335907284,-1.1031302021,-1.1828419358 C, $-1.7328029766,1.8590433115,2.0624094383$ $\mathrm{H},-2.7883187029,-1.3792420181,1.8839531473$ $P, 0.5945719151,0.3100013299,-0.9851321626$ $\mathrm{N}, 1.752558897,-0.702754131,-0.2707501015$ $\mathrm{N}, 0.9721579846,1.8710462309,-0.5276999516$ 
$\mathrm{N}, 0.8919861539,0.2820263706,-2.6245167182$ $\mathrm{N},-5.0273949835,-1.0115352336,-2.1470436917$ $\mathrm{N},-3.6809588759,-2.4011426585,-0.8759053346$ $\mathrm{N},-1.9313615841,3.1409748457,2.5695244204$ $\mathrm{N},-0.9529931503,1.050770809,2.8720792875$ C, $2.0404470289,0.2745218231,-3.2061173751$ C, $1.6801935519,2.3213107451,0.4443227936$ C,1.6072084298,-1.8539262786,0.3323528065 $\mathrm{N}, 2.5885627553,1.6280077194,1.2187097219$ $\mathrm{N}, 1.5779864916,3.6665155868,0.7821300982$ $\mathrm{N}, 2.1049951247,0.5666373496,-4.5588841318$ $\mathrm{N}, 3.2654301905,-0.0093205515,-2.6427892367$ $\mathrm{N}, 2.7831613839,-2.5252622799,0.6632903866$ $\mathrm{N}, 0.4712694946,-2.4702329785,0.7155014145$ $\mathrm{H},-2.8951249473,-2.4788123358,-0.2326822791$ $\mathrm{H},-3.7111950951,-3.0691679097,-1.6315770173$ $\mathrm{H},-5.7504898292,-1.7164256055,-2.1136495$ $\mathrm{H},-5.3691475784,-0.0680695814,-2.2596488817$ $\mathrm{H},-1.0494847997,0.0583958808,2.631775005$ $\mathrm{H},-1.0055198468,1.2541051933,3.8608058928$ H,-1.1274571482,3.5485416362,3.0285148494 $\mathrm{H},-2.3405513118,3.7519517813,1.8760953642$ $H, 3.2392901402,-0.1711357274,-1.6404319272$ $\mathrm{H}, 4.0703632649,0.4688979024,-3.0176526268$ $H, 1.1921429337,0.6481719463,-4.9828491339$ $\mathrm{H}, 2.7761662178,0.0446510203,-5.1042498852$ $\mathrm{H}, 2.5639404017,0.6247140061,1.0602171298$ $\mathrm{H}, 2.6493927486,1.9106506662,2.1861726184$ $\mathrm{H}, 2.4384401066,4.1208109786,1.0562506944$ $\mathrm{H}, 1.0329086908,4.1878102888,0.1099207465$ $\mathrm{H}, 0.5754479407,-3.2838667604,1.3031809368$ $\mathrm{H},-0.4424196593,-1.9735789471,0.8510936707$ $H, 3.5780790165,-2.2528182381,0.1057054205$ $\mathrm{H}, 2.7171007577,-3.5207115445,0.81789333$

$H F=-1817.2065159 \mathrm{NImag}=0$

\section{$24 \mathrm{H}+$}

Brutoformula: C5H22N17P2(1+)

1,1

N,-3.2328828858, $-0.511959894,-0.2091036501$ P, $-1.7612248827,-0.3198678589,0.475353543$ $\mathrm{H}, 3.5092666238,-2.6438436204,2.6048974168$ $\mathrm{N},-1.7922517834,0.9281513174,1.5668326822$ $\mathrm{N},-0.5952236464,-0.0289443823,-0.5837223358$ C, $-3.5974347864,-0.1806839503,-1.4193709409$ C,-2.4253339137, 0.9458977908,2.7164405813 $\mathrm{N},-1.5953570346,-1.7633295815,1.3721683789$ $\mathrm{P}, 1.00508803,-0.2109069861,-0.5478257696$ $\mathrm{N}, 1.4248464686,-0.9769559687,0.8575589326$ $\mathrm{N}, 1.817472789,1.2337878535,-0.670192417$ $\mathrm{N}, 1.5174268984,-1.1299121072,-1.8317738983$ $\mathrm{N},-2.8169683053,0.4413927116,-2.3421517858$ N, $-4.8722965241,-0.4823369843,-1.8067404441$ $\mathrm{N},-2.5159003734,2.1440528772,3.3713714775$ $\mathrm{N},-2.9717688096,-0.1257449244,3.3332387992$ C, $1.7168636341,-0.7199920344,-3.0578109933$ C,1.6998724712,2.2774963841,0.1148757222
C,2.4111513697,-1.8049669959,1.0723515349 $\mathrm{N}, 0.7132352058,2.5233747216,1.0038333153$ $\mathrm{N}, 2.6801669222,3.2318675054,0.0477024098$ $\mathrm{N}, 1.8824178981,-1.6576597231,-4.0328966511$ $\mathrm{N}, 1.7385271913,0.5803277382,-3.4525443487$ $\mathrm{N}, 2.625221356,-2.2263117019,2.3588025415$ $\mathrm{N}, 3.2419671325,-2.3152875699,0.1262078191$ $\mathrm{H},-5.4923928353,-0.7845016835,-1.072054989$ $H,-5.2926520209,0.0087097525,-2.5798017986$ $\mathrm{H},-3.0858920465,0.4083659416,-3.3129427761$ $\mathrm{H},-1.8215102077,0.4698385503,-2.1264684277$ $\mathrm{H},-2.7388885169,-1.0425826407,2.9615104396$ H, $-3.3646810841,-0.0541700789,4.2571689136$ H, $-3.1396861449,2.2442601814,4.1566655442$ $\mathrm{H},-2.3877544859,2.963790459,2.7998436756$ $\mathrm{H}, 1.886245426,1.2580542533,-2.7074057644$ $\mathrm{H}, 2.0035665361,0.8250261436,-4.3930467083$ H,1.8437106779,-2.6247440918,-3.7578315499 $\mathrm{H}, 2.2841786364,-1.43320466,-4.9278585451$ $\mathrm{H},-0.1136215009,1.9306219614,1.1028398828$ $\mathrm{H}, 0.8349379757,3.2537400312,1.6864276387$ $H, 2.4790669146,4.1884612112,0.2926093896$ $H, 3.4057803964,3.0768529343,-0.6328603922$ $H, 3.8130208816,-3.1166492998,0.3440010955$ $H, 2.927548915,-2.1989895679,-0.8342681633$ $H, 2.18755651,-1.6675914507,3.0745031834$ $\mathrm{H},-1.9614723343,-2.5656433497,0.8690046804$ $\mathrm{H},-0.6177053887,-1.9197813262,1.6143429927$

$H F=-1817.6905977 \quad \mathrm{NImag}=0$

25

Brutoformula: C3H13N10P1 0,1 $\mathrm{N},-1.7205423524,0.9258172966,2.4326983296$ P, $-1.7903810396,0.7059934324,0.7295639453$ $\mathrm{N},-2.048657207,2.3152954696,0.3099982706$ $\mathrm{N},-2.9421427396,-0.1246585812,0.0673338707$ $\mathrm{N},-0.1757830702,0.192704472,0.5511017488$ $\mathrm{H},-2.7632351193,-1.1179539396,-0.0229488914$ $\mathrm{H},-1.3231077689,0.1213887795,2.9040655548$ H, $-2.6454888348,1.1051027851,2.8104304806$ $\mathrm{H},-2.144577768,2.4513094458,-0.6867995627$ $\mathrm{H},-1.395207185,2.9685324828,0.7213312428$ C, $0.4342873051,0.1424545725,-0.6059949477$ $\mathrm{N}, 1.7370802317,-0.3364000144,-0.7304622502$ $\mathrm{N},-0.1986448208,0.6003615105,-1.7413161369$ C,2.5102565968,-0.5442565166,0.3109178958 C, $0.1219343281,0.2866363441,-2.9642469947$ $\mathrm{N}, 3.8283415316,-0.8675901428,0.0702607351$ $\mathrm{N}, 2.1459437721,-0.447934813,1.6064909916$ N, $1.2153540343,-0.4098207523,-3.3911242321$ $\mathrm{N},-0.7416371839,0.6776821582,-3.960949303$ H, 1.1276897969,-0.9641701126,-4.2287375866 $H, 1.8043082111,-0.7410376608,-2.6302052045$ $\mathrm{H},-1.5167978295,1.2402040969,-3.6453380329$ $\mathrm{H},-0.3568560739,0.912558789,-4.8629263387$ $H, 2.8495650586,-0.2840436011,2.309244263$ 
$\mathrm{H}, 1.1752776207,-0.1241210145,1.7240973894$ $\mathrm{H}, 4.2939776275,-1.464229391,0.7372037824$ $\mathrm{H}, 4.0489831378,-1.0491465292,-0.8963118812$

$H F=-1011.3141767 \quad \mathrm{NImag}=0$

\section{$25 \mathrm{H}+$}

Brutoformula: C3H14N10P1(1+)

1,1

N,-1.672888453,1.994807072,1.0325095288

P, $-1.7009184887,0.3438879754,0.8347188102$

$\mathrm{N},-2.7370604412,-0.3408727724,-0.269739982$

H,4.0485119732,-1.2647776719,-1.0246413779 $\mathrm{N},-0.1926199539,-0.196495794,0.5863182848$

$\mathrm{N},-2.3884271456,-0.1362893259,2.2576823443$ $\mathrm{H},-1.0869353416,2.506385065,0.3858286695$ $\mathrm{H},-2.5345118547,2.4733312203,1.2626356633$ $\mathrm{H},-3.7304392837,-0.1712892878,-0.1771390172$ $\mathrm{H},-2.4111507884,-0.3443334596,-1.2276176957$ C, $0.5098884634,0.0519716798,-0.5303265939$ $\mathrm{N}, 1.7698913498,-0.4220448437,-0.7093257161$ $\mathrm{N},-0.0968096735,0.8110838114,-1.4903500064$ C,2.4162477649,-1.1677370535,0.1919371801 C, $0.4455363259,1.1391040636,-2.6616743769$ $\mathrm{N}, 3.6663021335,-1.5585302147,-0.1424331613$ $\mathrm{N}, 1.9323798717,-1.553870168,1.3779138731$ $\mathrm{N}, 1.669784656,0.8002240342,-3.0873811521$ $\mathrm{N},-0.333480154,1.8768373312,-3.4889294481$ $H, 2.0053033874,1.0421250766,-4.0054220172$ $\mathrm{H}, 2.2099147529,0.2245292322,-2.4441354295$ $\mathrm{H},-1.2250325735,2.1910208856,-3.1451653123$ $H, 0.0108450695,2.2617949998,-4.3526134488$ $H, 2.4699995663,-2.1176252349,2.0162140986$ $\mathrm{H}, 0.9862893879,-1.2422657774,1.5957997994$ $\mathrm{H}, 4.2430121843,-2.1103459761,0.4701640881$ $\mathrm{H},-2.0426697296,0.2768935613,3.1128792149$ H,-2.6582027813,-1.1060382154,2.3502265554

$H F=-1011.7686103 \mathrm{NImag}=0$

\section{6}

Brutoformula: C9H25N22P1

0,1

$\mathrm{N}, 0.4463910418,-0.1326932767,-1.3532480551$ $P, 0.1713907226,0.3798785026,0.2304432508$ $\mathrm{N}, 1.2506327296,0.0042399062,1.3283571271$ $\mathrm{N},-1.4846527692,0.0884511346,0.4736494254$ $\mathrm{N}, 0.1365628602,2.0524840952,0.1131748843$ C, $0.318383257,-1.3197976851,-1.8671877397$ C,-2.0421272791, $-0.7801938071,1.2537623503$ $\mathrm{H}, 1.1583647901,-0.9383007665,1.6879677614$ C, $1.0789496782,2.8467475297,-0.3099750218$ $\mathrm{N}, 0.699273734,-1.5779781526,-3.1857872007$ $\mathrm{N},-0.236340226,-2.3571794113,-1.1351546529$ $\mathrm{N},-3.4245240578,-0.9848616847,1.2760051147$ $\mathrm{N},-1.3125634105,-1.5312365944,2.1663870443$ $\mathrm{N}, 0.9762968204,4.2248323045,-0.2332586874$
$\mathrm{N}, 2.2387294122,2.4674663217,-0.9787388698$ C, $-0.215409463,-3.6136522763,-1.4785364297$ C, $1.3062347411,-0.6806487594,-3.9314062213$ C,-1.6133119069,-2.7265337556,2.5280939581 C,-4.2483971637,-0.2202608131,0.5979350361 C, $-0.0484397672,4.8167484336,0.3240921777$ C, $3.3123570748,2.0703140832,-0.3884640904$ N,-0.7225585176, $-4.5325450594,-0.580831828$ $\mathrm{N}, 0.2597255726,-4.1613175322,-2.639207041$ $\mathrm{N}, 1.7011979795,-1.0921648013,-5.1966348813$ $\mathrm{N}, 1.6032109505,0.5852046656,-3.6004478507$ $\mathrm{N},-0.9171601866,-3.301524139,3.5762291068$ $\mathrm{N},-2.5595678384,-3.5549482317,1.9327253919$ $\mathrm{N},-5.6026163124,-0.4109976856,0.8038157339$ $\mathrm{N},-3.9056982302,0.7502950546,-0.2709217423$ N,4.4588054545,1.9295336838,-1.1686835647 $\mathrm{N}, 3.4302698714,1.7604333267,0.9427535568$ $\mathrm{N},-1.090449054,4.2253290169,0.9504098587$ $\mathrm{N},-0.0780920781,6.2015708088,0.2612171934$ $\mathrm{H}, 0.6280208957,-5.0991242623,-2.5998458906$ $\mathrm{H}, 0.7001518292,-3.4722810424,-3.2483214895$ $\mathrm{H},-1.2650879098,-4.1355778681,0.1790425199$ H,-1.1288298073,-5.36413192,-0.9842676939 $H, 2.2655121358,1.109755641,-4.1483172879$ $H, 1.4069673811,0.8528335318,-2.6290088914$ $\mathrm{H}, 1.7395418829,-0.3777949616,-5.9092199413$ H,1.2475937451,-1.9412019964,-5.4987273321 H, $-0.1097618857,-2.761021353,3.853387139$ $\mathrm{H},-0.7443863649,-4.2950867932,3.5160576111$ H, $-2.9380291343,-4.2609333026,2.5517923689$ H, $-3.2863644828,-2.9810104234,1.5018256391$ $\mathrm{H},-2.8874047972,0.9026134455,-0.3313889702$ H, $-4.5767256967,1.4515109393,-0.5394016241$ $\mathrm{H},-6.2165159494,-0.2576299601,0.0175133896$ $\mathrm{H},-5.8202483017,-1.2225743228,1.3615635357$ H,4.4745407953,2.5441854624,-1.9687958348 $H, 5.3375095173,1.8851373293,-0.675737117$ H,4.3191709727,1.3562923287,1.2047226354 $\mathrm{H}, 2.6320236301,1.1839936203,1.2973824684$ $\mathrm{H}, 0.8045835971,6.5863204764,-0.0438378159$ $\mathrm{H},-0.4858925612,6.680675008,1.0514586091$ H,-1.9323197776,4.7454585774,1.1348513199 H,-1.0862173335,3.2013222304,0.8677591387

$H F=-1904.5114854 \quad \mathrm{NImag}=0$

\section{$26 \mathrm{H}+$}

Brutoformula: $\mathrm{C} 9 \mathrm{H} 26 \mathrm{~N} 22 \mathrm{P} 1(1+)$

1,1

$\mathrm{N}, 0.0038144579,-0.1234822657,-1.609092107$

$\mathrm{P},-0.1790320786,0.0875337019,0.0156362162$ H, $-6.272728161,-0.8664952259,1.1615483662$ $\mathrm{N}, 0.7341538878,-1.0046857881,0.8519560666$ $\mathrm{N},-1.7313831476,-0.3816835036,0.3615128906$ C, $1.1491142762,0.005127871,-2.2674829256$ C, $1.7802408302,-0.8455673954,1.6237367217$ $\mathrm{N}, 0.1376423294,1.6588918302,0.4788874476$ C,-2.8103613406,0.3293441793,0.0951910025 
$\mathrm{N}, 2.3051538628,0.2131513646,-1.5721992869$ $\mathrm{N}, 1.1937402806,-0.1037283524,-3.6415884913$ $\mathrm{N}, 2.5313671984,-1.9090343092,2.0723181867$ $\mathrm{N}, 2.1407911759,0.4062159761,2.089936217$ $\mathrm{N},-4.0707103106,-0.1089592575,0.4403390565$ $\mathrm{N},-2.6692600549,1.5506600258,-0.5201574168$ C, $0.1220377264,-0.3408492488,-4.3824189694$ C,3.4620897007,0.547411903,-2.1033164153 C.3.3584108656,0.7440423471,2.4049804956 C,2.2742976684,-3.1639947541,1.7433189722 C,-4.2799825403,-1.2318158853,1.1122206614 C, $-3.6561382466,2.3104589646,-0.945429266$ $\mathrm{N},-1.1215260489,-0.5506019016,-3.9260705017$ $\mathrm{N}, 0.3069699826,-0.3559523666,-5.7390546154$ $\mathrm{N}, 4.4948501296,0.7755449692,-1.2367743918$ $\mathrm{N}, 3.737686004,0.7118241802,-3.4170002275$ $\mathrm{N}, 3.5564323223,1.9438015794,3.0236423475$ $\mathrm{N}, 4.4921047205,0.0214301166,2.1073508641$ $\mathrm{N}, 1.2399877792,-3.5925518462,0.9997363039$ $\mathrm{N}, 3.1562841121,-4.1054662678,2.1991336778$ $\mathrm{N},-3.3085504655,3.538990328,-1.435045524$ N,- $-4.9705712769,1.9958604782,-0.9628055144$ $\mathrm{N},-5.5832161809,-1.5788009964,1.3369017273$ $\mathrm{N},-3.3309342999,-2.0584889379,1.5739824764$ $\mathrm{H},-0.3749363717,-0.8091274923,-6.3267455344$ $H, 1.2627901357,-0.4114086458,-6.0520790107$ $\mathrm{H},-1.22228969982,-0.4400302791,-2.9091509215$ $\mathrm{H},-1.9075023337,-0.6134957149,-4.5520933819$ $\mathrm{H}, 4.5531257059,1.2237995388,-3.71173084$ $H, 2.9460891033,0.5658925778,-4.0391215372$ $H, 5.440641482,0.6958041406,-1.5758058526$ $\mathrm{H}, 4.3440767975,0.5124479627,-0.2722636079$ $\mathrm{H}, 2.758012601,2.5547645875,3.0886524589$ $\mathrm{H}, 4.4612460454,2.3859490709,2.9943022913$ $H, 5.3178877343,0.2450340799,2.6464047853$ $H, 4.2803765528,-0.9757481809,2.0580792325$ $\mathrm{H}, 3.7773345225,-3.7996498074,2.9315801201$ $H, 2.8735205191,-5.072256715,2.2369862908$ $\mathrm{H}, 0.681460164,-2.8413188178,0.5841553203$ H,1.2133684542,-4.5351236064,0.6455362963 $\mathrm{H},-2.3255881917,3.675482783,-1.611304419$ H, $-3.946208837,4.0393671816,-2.033687828$ $H,-5.661699189,2.7132088497,-1.1141089665$ $\mathrm{H},-5.1990981459,1.1606248043,-0.4244361753$ H, $-2.3719856388,-1.7971648076,1.3169066417$ H, $-3.5614540465,-2.9290338976,2.023625887$ $\mathrm{H},-5.8073677723,-2.2475051104,2.0563921644$ $\mathrm{H},-0.6719379006,2.265705993,0.4502652583$ $\mathrm{H}, 0.7317010965,1.71843924,1.3001273336$

$$
H F=-1905.004462 \quad \mathrm{NImag}=0
$$

\section{$27 a$}

Brutoformula: H7N4P1

0,1

N, $0.178305514,-0.1674682412,-1.5762636726$ $P, 0.1802865616,-0.0612009555,0.0963682241$ $\mathrm{N},-0.1594766119,1.4984897528,0.6642503898$
$\mathrm{N}, 1.5592737231,-0.6321160785,0.5547953751$ $\mathrm{N},-1.3546489346,-0.7227472835,0.4541740123$ $\mathrm{H}, 1.8116206766,-0.4886574738,1.5252107485$ $H, 1.0095128419,-0.5736506432,-1.9796302884$ $\mathrm{H},-0.680339463,-0.3791279872,-2.0597967774$ H, $-1.4240497651,-1.7121394917,0.2453023419$ $\mathrm{H},-1.6624112875,-0.5476481048,1.4035758384$ $\mathrm{H}, 0.6353354047,2.1234901238,0.638076195$ $\mathrm{H},-0.9961294678,1.9477120328,0.3117465393$

$H F=-564.7129759 \mathrm{~N} / \mathrm{mag}=0$

\section{$27 \mathrm{aH}+$}

Brutoformula: H8N4P1(1+) 1,1 $N, 0.1593628962,-0.4786332728,-1.579796556$ $\mathrm{P}, 0.1322216269,-0.0758222591,0.0119434345$ $\mathrm{N},-0.0106396915,1.4546601094,0.5892343538$ $\mathrm{H},-0.9074358292,1.9217306923,0.5562448408$ $\mathrm{N},-1.2575980632,-0.7800269957,0.5298253743$ $\mathrm{N}, 1.6391650806,-0.4995017235,0.5082930099$ $H, 0.9895706052,-0.2982116036,-2.1290218745$ $\mathrm{H},-0.6986531933,-0.4643010391,-2.1155776964$ H,-1.5137529975,-1.6969542721, 0.1876938259 $\mathrm{H},-1.6131631995,-0.5714222996,1.453656274$ $\mathrm{H}, 0.7815588337,2.0823666762,0.5461265632$ $H, 1.9586639815,-0.2265055814,1.4285744852$ $\mathrm{H}, 2.0573026411,-1.354793328,0.1659498551$

$H F=-565.1225138 \quad N \mid m a g=0$

\section{$27 \mathrm{c}$}

Brutoformula: $\mathrm{C} 6 \mathrm{H} 11 \mathrm{~N} 4 \mathrm{P} 1$ 0,1 $\mathrm{N},-0.3651527462,0.2234814924,-1.1154526423$ $P,-0.4323884296,0.4857962624,0.420472361$ C, $0.3052616869,-0.7393328442,-1.8596285985$ $\mathrm{N}, 1.077736258,0.7598890212,1.1220620074$ $\mathrm{N},-1.5531718359,1.7213206547,0.589126481$ $\mathrm{N},-1.0262380696,-0.5790836178,1.5958219013$ C, $0.6844775163,-1.7132507845,-4.0648275058$ C, $1.5790290448,-2.6443636303,-3.5324739275$ $\mathrm{H}, 2.0643931626,-3.3728017443,-4.1715387341$ $\mathrm{H},-1.6313706127,2.324781364,-0.217345756$ C, $0.0596456391,-0.779616753,-3.2475010774$ $\mathrm{H}, 2.534122189,-3.3268959753,-1.729314009$ $\mathrm{H},-0.6385946517,-0.0607811548,-3.6604409822$ $\mathrm{H}, 1.4561794249,-1.6668785648,-0.2800122815$ $\mathrm{H},-2.0025718085,-0.8187877608,1.4743172475$ $\mathrm{H}, 1.139948774,1.0028076177,2.1016591581$ $H, 1.7592247337,1.231858443,0.5444477237$ $\mathrm{H},-0.4630158694,-1.4056264602,1.7525188925$ C, $1.2176309633,-1.6808650111,-1.3381266553$ C, $1.837813737,-2.6165575845,-2.1637569598$ $\mathrm{H},-1.5966450865,2.2110871548,1.4716475771$ $\mathrm{H}, 0.4700014075,-1.7161324047,-5.1286773363$ 
$H F=-795.819578 \mathrm{NImag}=0$

\section{$27 \mathrm{cH}+$}

Brutoformula: C6H12N4P1(1+)

1,1

H,- $-1.8730171894,2.1250292576,-0.530877195$

$P,-0.4488061376,0.5253547331,0.3533478668$

$\mathrm{N},-0.7570236836,-0.3350926588,-1.0124489145$

$\mathrm{N}, 1.1460695896,0.8756880508,0.2510766955$

$\mathrm{N},-1.6482312453,1.6540368655,0.3353459538$

$\mathrm{N},-0.5799316336,-0.0637453401,1.8869202967$

$\mathrm{C}, 0.8261370267,-0.8071468468,-2.8218713715$

$\mathrm{H},-1.7355775421,-0.4329956032,-1.2588235433$

$H, 1.635914671,1.3002534776,1.025595303$

$\mathrm{H}, 1.6083467651,0.9373160932,-0.6452522812$

$\mathrm{H}, 1.3809128069,-4.3992540003,-1.4784132303$

C, $1.6995741941,-1.6716600128,-3.479894964$

C, $0.3562612508,-2.5346072841,-1.1878183128$

C, $1.2310446067,-3.3929564406,-1.8506043058$

$\mathrm{H},-1.4952136354,-0.2352156695,2.2819489172$

C,0.1625463941,-1.242675382,-1.6752331533

C, $1.9042208504,-2.9614221852,-2.9927598135$ $\mathrm{H}, 0.1417780814,-0.6767710325,2.2418244276$

$\mathrm{H}, 2.2112434863,-1.3396450888,-4.3752195427$

$\mathrm{H}, 2.5809073221,-3.6328817908,-3.5074274958$ $\mathrm{H},-1.8105689904,2.2176724348,1.1595314389$ $H, 0.6413566508,0.1895262668,-3.2073966821$

$\mathrm{H},-0.1827264317,-2.8707012329,-0.3092244838$

$H F=-796.2240182 \quad \mathrm{NImag}=0$

\section{$28 \mathrm{c}$}

Brutoformula: $\mathrm{C} 12 \mathrm{H} 23 \mathrm{~N} 4 \mathrm{P} 1$

0,1

N, $-0.2198870146,0.1653680745,-1.1667446749$ P, $-0.2157881617,0.5480725863,0.3492911837$ C, $0.2772946498,-0.9079849065,-1.8875912739$ $\mathrm{N}, 1.2326393946,0.7987588893,1.2080179465$ $\mathrm{N},-0.9293628308,2.0754176633,0.4263411108$ $\mathrm{N},-0.9783159648,-0.5949102565,1.350532903$ C, $-1.0607058844,-0.4723898076,2.8052313991$ C, $-2.0660402196,-1.3969985364,0.7856945629$ C, $2.047687097,-0.3531136514,1.6130514454$ C,2.0727597383,1.9326806952,0.8031012896 C,-1.1797407168,2.7267366676,1.707448133 C,-1.7362685533, 2.6029924322,-0.6727480676 $\mathrm{H},-2.0034404739,-0.0079534181,3.1266238937$ $\mathrm{H},-0.2324005246,0.1200699648,3.1888875913$ $\mathrm{H},-1.0084639781,-1.4686770921,3.2594383367$ $\mathrm{H},-3.0507944961,-0.9638226649,1.0115831536$ $\mathrm{H},-2.0337169343,-2.4058237736,1.2109324233$ $\mathrm{H},-1.9594233236,-1.4752932896,-0.2941260181$ $\mathrm{H},-1.052413353,3.8093148084,1.5953446618$ $\mathrm{H},-0.4713670163,2.3847177913,2.4609710546$ $H,-2.2003879083,2.5471452532,2.0744190597$ H, $-1.5330063784,3.6739069934,-0.7892508654$ $\mathrm{H},-2.8116794409,2.4781774649,-0.4830757545$
$\mathrm{H},-1.4743515421,2.085222757,-1.5915124854$ $\mathrm{H}, 1.4164861744,-1.1915119394,1.8992060521$ $\mathrm{H}, 2.6603300825,-0.0700627985,2.4755636553$ $\mathrm{H}, 2.7176920201,-0.6814439776,0.8084618728$ $\mathrm{H}, 2.6963809113,2.2342399905,1.6507601991$ $\mathrm{H}, 1.4533831688,2.7771779844,0.507417617$ $\mathrm{H}, 2.7326863577,1.6736730424,-0.0353724555$ C,1.239363339,-3.0195407529,-3.5286456419 C, $0.325339473,-0.7885589706,-3.293923723$ C, $0.7213016139,-2.1286343919,-1.3341430309$ C,1.1950506089,-3.1596590809,-2.1432661981 C, $0.7969629984,-1.8212780936,-4.0941317688$ $\mathrm{H},-0.0151841481,0.1405053466,-3.7367319433$ $\mathrm{H}, 0.6888912067,-2.2690002955,-0.2598624135$ $H, 1.5301178595,-4.0832632505,-1.6815687569$ $\mathrm{H}, 0.8205191493,-1.6901693926,-5.1712735533$ H,1.6078530187,-3.8240880639,-4.1543509192

$H F=-1031.6908928 \mathrm{NImag}=0$

\section{$28 \mathrm{cH}+$}

Brutoformula: C12H24N4P1(1+) 1,1

N, $-0.3644937475,0.2052656448,-1.1052062671$ $\mathrm{P},-0.3736523411,0.473087824,0.5361422539$ C, $0.3393863048,-0.7272727728,-1.9347355082$ $\mathrm{N}, 1.1865712091,0.3175421809,1.0389983207$ $\mathrm{N},-0.9853043708,1.9820991834,0.8333768126$ $\mathrm{N},-1.4099287727,-0.5629529277,1.29102338$ C, $-1.9334304677,-0.3122316007,2.6455660032$ C, $-1.7556685412,-1.890311669,0.7541598981$ C, $1.546962155,-0.2343919199,2.3535847028$ C, $2.327298741,0.8721750885,0.2866689961$ C, $-0.1258355784,3.1617535757,1.0182618044$ C, $-2.3896386462,2.3078055998,0.5267306763$ $\mathrm{H},-3.0258703226,-0.3565481481,2.6273265611$ $\mathrm{H},-1.6318791038,0.6711721622,3.001575926$ $\mathrm{H},-1.5698229023,-1.0698930024,3.3463468548$ $\mathrm{H},-2.8338543159,-2.0374661655,0.8544170355$ $\mathrm{H},-1.2428973357,-2.6858920688,1.3035654906$ $\mathrm{H},-1.4993169415,-1.9648798159,-0.29970837$ $\mathrm{H},-0.003779167,3.725959566,0.0875360706$ $\mathrm{H}, 0.8539402018,2.8697643754,1.3891953875$ $\mathrm{H},-0.5865722771,3.8151396288,1.7624858335$ $\mathrm{H},-2.465995528,2.8953371051,-0.3950417143$ $\mathrm{H},-2.812049075,2.8968538412,1.3445413217$ H, $-2.9807815043,1.3992720686,0.4172086352$ $\mathrm{H}, 0.7130475118,-0.7821201592,2.7868045206$ $\mathrm{H}, 1.8518121727,0.5553312359,3.0472441787$ $\mathrm{H}, 2.3812796647,-0.9292295213,2.2288904037$ $\mathrm{H}, 2.8282399303,1.649874084,0.8706126427$ $\mathrm{H}, 1.9988264244,1.2989818979,-0.6589074113$ $\mathrm{H}, 3.0437109511,0.0755927865,0.0727249554$ C, $1.6703836767,-2.4771954566,-3.6660164481$ C, $0.3220004137,-0.5028454409,-3.3149178919$ C, $1.0225968769,-1.832223934,-1.422428971$ C, $1.688460272,-2.6960638942,-2.2917875629$ C, $0.9800903703,-1.3776184463,-4.1730468569$ 
$\mathrm{H},-0.2058985618,0.3551780883,-3.7192469285$ $\mathrm{H}, 1.0447353526,-2.0276627021,-0.35820196$ $\mathrm{H}, 2.2171604415,-3.5501273127,-1.8850060861$ $H, 0.953893401,-1.1942846635,-5.240559132$ $\mathrm{H}, 2.1846844,-3.1559293261,-4.3348678807$ $\mathrm{H},-0.9584109738,0.8389550116,-1.6253096766$ $H F=-1032.1055386 \quad \mathrm{NImag}=0$

\section{9}

Brutoformula: C4H13N4P1

0,1

$N, 0.5679084466,-1.1538476981,-2.3160015799$ $\mathrm{P}, 0.5960464389,-1.3095915567,-0.7607671138$ $\mathrm{N}, 2.1583109226,-1.4912348301,-0.1102833219$ $\mathrm{N},-0.1024069062,-2.5942105374,0.1183209632$ $\mathrm{N},-0.2602037927,-0.013317736,-0.1433418793$ $\mathrm{H},-1.0931933631,-2.7058307871,-0.0612890298$ $H, 0.379982192,-3.4780474728,0.0070899095$ $H, 2.262197453,-1.5587909107,0.8944472329$ $\mathrm{H}, 2.8636968509,-0.9041983559,-0.5337241778$ $\mathrm{H}, 1.0660304355,-1.8629566361,-2.840797441$ C, $-0.3403302688,0.2783056327,1.2992421188$ C, $-0.5793827004,1.1868703448,-0.9559385378$ $\mathrm{H}, 0.1819954322,1.3614654971,-1.7159014114$ C, $-0.6793804234,2.3162195471,0.0786702248$ $\mathrm{H},-1.5299529812,1.0380389933,-1.4786904212$ $\mathrm{H}, 0.6604432099,0.4159634946,1.7377805194$ $\mathrm{H},-0.8284858608,-0.535200707,1.8396797062$ C,-1.1284662629,1.5924815066,1.3558556652 $\mathrm{H}, 0.3035782247,2.7726168723,0.2354851007$ $\mathrm{H},-0.9295242204,2.1560461389,2.2698787496$ $\mathrm{H},-1.3666047795,3.1049141351,-0.2345840193$ H,-2.2022580488,1.3843050655,1.3148687426

$H F=-720.7785721 \quad N \mid m a g=0$

\section{$29 \mathrm{H}+$}

Brutoformula: C4H14N4P1(1+)

1,1

H,-1.8691709922,1.1154736879,1.6501786809 $\mathrm{P}, 0.5825238495,-1.3036970208,-0.676705932$ $\mathrm{N}, 1.8700907315,-1.6905440693,0.2750471055$ $\mathrm{N},-0.3455719557,-2.6650732296,-0.5297121997$ $\mathrm{N}, 0.1348599699,0.1816552393,-0.1657338455$ H, $-1.1487342789,-2.7847453689,-1.1325764555$ $\mathrm{H},-0.4518761305,-3.0961188774,0.3788613716$ $H, 2.2508580064,-2.6267534882,0.2366929706$ $\mathrm{H}, 2.5491035095,-0.980377661,0.512311606$ $\mathrm{N}, 0.683912908,-1.1680178468,-2.3153025812$ C, $0.2029574128,0.6044222254,1.2749263178$ C, $-0.800261086,1.0728043831,-0.929519015$ $\mathrm{H},-0.3619931925,1.3706169671,-1.8818147436$ C, $-1.0086252381,2.2585558013,0.0163386246$ $\mathrm{H},-1.7432260505,0.5548421157,-1.128268914$ $H, 1.1751596528,1.0662518336,1.4687035712$ $\mathrm{H}, 0.0879188478,-0.2486158933,1.944246414$
C, $-0.9314814647,1.6241146523,1.4096316394$ $\mathrm{H},-0.206443988,2.9896601878,-0.1160321624$ $\mathrm{H},-0.730764417,2.3475437799,2.2003070511$ $\mathrm{H},-1.9562403001,2.7626614139,-0.1748865917$ $\mathrm{H}, 0.8119788019,-2.0039749552,-2.8701121657$ $H, 1.0909675411,-0.3392578611,-2.7261444474$

$H F=-721.1966448 \quad \mathrm{NImag}=0$

\section{$30 a$}

Brutoformula: C12H25N4P1

0,1

$\mathrm{N},-0.3973434587,-0.581751554,-1.3414016204$

$\mathrm{P},-0.4585392402,-0.6917988975,0.3307582561$

$\mathrm{N}, 1.0856699931,-0.7092637032,1.0161622445$

$\mathrm{N},-1.3319766675,-1.9646534152,0.6197238922$

$\mathrm{N},-0.9501503607,0.8780888807,0.7842255375$

$\mathrm{H},-1.4564282705,-2.1933908062,1.599345705$

C, $0.4633776572,0.3615726215,-2.0715037686$

C,-1.0570450574,-1.5375489381, -2.2522144044

C, $-0.9914196022,1.2384641556,2.2259422069$

C,-2.1495110262,1.4270909862,0.1011231392

C, $1.8342223904,-1.98785363,1.0686749467$

C, $2.0027435282,0.4403742775,1.1789734018$

$\mathrm{H}, 1.5001099536,0.3240407289,-1.7202333585$

$\mathrm{H}, 0.1129501989,1.3941394935,-1.9426452556$

C, $0.3565496001,-0.0879641186,-3.5415169791$

$\mathrm{H},-0.516480152,-2.4921182875,-2.2894839881$

C, $-0.9931001707,-0.8185843866,-3.6031075851$

$\mathrm{H},-2.069370722,-1.7524673155,-1.9129822916$ $\mathrm{H}, 1.9228530342,0.8529026137,2.1932475322$

$\mathrm{H}, 1.166454098,-0.7849540979,-3.7781330215$

$\mathrm{H}, 0.4298679788,0.7520757972,-4.2354452934$

$H, 1.7650169306,1.24379927,0.4809417782$

$\mathrm{H},-1.8126060708,-0.0970651979,-3.682473614$

H,-1.0675089189,-1.5077950908,-4.4472339052

$\mathrm{H},-1.8771241195,1.8744880223,-0.8576987159$

C, $-2.7124856256,2.4569518591,1.0873598399$

H, $-2.8902362515,0.6408088849,-0.0913367619$

$\mathrm{H},-0.2147614633,1.9800607192,2.4475349408$

$\mathrm{H},-0.8043927429,0.3687135806,2.8615335534$

C,-2.3866856774,1.8355565166,2.4509889407

H, $-2.1943894199,3.41489888501,0.9740635212$

$\mathrm{H}, 1.359833675,-2.6939983404,1.7527654947$

$\mathrm{H},-3.7794260284,2.6320992691,0.9339630662$

C,3.3970460349, $-0.1585509551,0.9637360721$

$\mathrm{H},-2.4047681676,2.5550562034,3.2727692775$

H,-3.1030510955,1.0407868208,2.6803557809

C,3.2424338968,-1.5794205335,1.5244313464

$\mathrm{H}, 1.867052886,-2.4637090141,0.0804366521$

$\mathrm{H}, 4.0078223038,-2.2726778766,1.169650942$

H,3.2935034677,-1.5568015144,2.6177686588

$\mathrm{H}, 4.1817156373,0.4201345926,1.4565742423$

$H, 3.6295770438,-0.1997364684,-0.1056404049$

$H F=-1032.9040286 \quad N I m a g=0$

$30 \mathrm{aH}+$ 
Brutoformula: C12H26N4P1(1+)

1,1

$\mathrm{N},-0.4080025941,-0.5846470977,-1.4580050541$

P. $-0.2775568025,-0.6954417624,0.1754633594$

$\mathrm{N}, 1.2560173937,-0.4596395992,0.7186242311$

$\mathrm{H}, 3.8470348546,0.8394659229,0.348985123$

$\mathrm{N},-1.3317573693,0.4026523759,0.8019169573$

$\mathrm{N},-0.6357341423,-2.2399660648,0.6703419952$ C, $0.7409283074,-0.8544070443,-2.3801019691$

C,-1.6992294831, $-0.6331106843,-2.2010497243$

C,- $-1.8602369779,0.2714395149,2.1925498983$

C, $-1.5482134638,1.7873053274,0.2825568855$

C,2.3462971933,-1.4760948161,0.7829288624

C, $1.786765057,0.9029687625,1.0307456887$

$\mathrm{H}, 1.3214188044,-1.7210804411,-2.05855393$

H,1.4010561715,0.0161688133,-2.4013893706

C, $0.0741524289,-1.0970518089,-3.7441116366$

$\mathrm{H},-2.1628378598,-1.6241603436,-2.1176447867$

C,-1.2699241834,-0.3637557759,-3.6437850038

$\mathrm{H},-2.3995006339,0.1054042126,-1.8131622766$

$\mathrm{H}, 1.2894724374,1.2939821221,1.9221682157$

$\mathrm{H},-0.0934889357,-2.1670252645,-3.8933530627$

$\mathrm{H}, 0.6965970239,-0.7417683615,-4.5658182522$

$\mathrm{H}, 1.6166700594,1.6014700981,0.2078682522$

$\mathrm{H},-1.1375043228,0.7106711315,-3.7984138489$

$\mathrm{H},-2.006649779,-0.7212276866,-4.3640325707$

$\mathrm{H},-0.6504832608,2.185966967,-0.1902828166$

C, $-1.970949625,2.5803781397,1.5236840666$

$\mathrm{H},-2.3485394342,1.779962746,-0.462995962$

$\mathrm{H},-1.0397536505,0.2438001438,2.9193393274$

$\mathrm{H},-2.4459725567,-0.6434014899,2.2957785564$

C,-2.7054238836, $1.5369020785,2.3752028272$

H,-1.0902382796,2.9530524383,2.0547098369

$\mathrm{H}, 1.9727006863,-2.4197370487,1.1763864582$

$\mathrm{H},-2.5924765873,3.4384066366,1.2648696277$

C. $3.288273944,0.6729026443,1.2736826411$

H,-2.7906145474,1.8195292533,3.4248746335

$\mathrm{H},-3.7149126637,1.3721719915,1.988860511$

C, $3.3803020662,-0.8023108634,1.6853477983$

$H, 2.7638920389,-1.6612414958,-0.2125600474$

$\mathrm{H}, 4.3776831693,-1.2214857436,1.5477292812$

H,3.1017876048,-0.9292907109,2.7353376798

$H, 3.683490471,1.3556175372,2.0263794042$

$\mathrm{H},-0.5285191072,-2.5011958703,1.6416248904$

$\mathrm{H},-1.3858804885,-2.7328949428,0.2047939154$

$H F=-1033.335283 \quad \mathrm{NImag}=0$

\section{1}

Brutoformula: H11N7P2

0,1

$\mathrm{N},-0.1589202612,0.7003183268,-2.6834835092$ $P, 0.4839715209,0.5774205854,-1.1414841965$ $\mathrm{N}, 2.1476310027,0.4213870093,-1.390130862$

$\mathrm{N},-0.2276477881,-0.6277375911,-0.4098526245$ $\mathrm{N}, 0.3880788237,2.0963893795,-0.4448813374$

$\mathrm{P},-0.5761614242,-0.7556688197,1.1854890028$
$\mathrm{N},-0.1275581291,0.5629909551,1.9463648535$ $\mathrm{N}, 0.0484443391,-2.2932803199,1.5785948103$ $\mathrm{N},-2.2022014356,-1.1315784804,1.4849202375$ $\mathrm{H}, 0.4987400243,0.7983421753,-3.4435294439$ $\mathrm{H},-0.906335728,0.0491233528,-2.8780313827$ $\mathrm{H},-0.2993947674,2.6979115352,-0.87999555375$ $\mathrm{H}, 0.22686686699,1.9860276342,0.5696223326$ $\mathrm{H}, 2.7121223345,1.0507081463,-0.8352369688$ $H, 2.5050998398,-0.5251309615,-1.385087064$ $\mathrm{H},-2.8255433996,-0.3369702496,1.4323742626$ $\mathrm{H},-2.5714695764,-1.9353143924,0.9916126802$ $H, 1.0097981721,-2.4220914383,1.2896908586$ $\mathrm{H},-0.0698973911,-2.5507953835,2.5515405107$ $\mathrm{H},-0.3174607081,0.5835936815,2.9424785837$

$H F=-1072.8648405 \quad$ NImag $=0$

$31 \mathrm{H}+$

Brutoformula: H12N7P2(1+) 1,1

$H, 2.7280662062,-0.154618448,-1.2452631384$ $\mathrm{P}, 0.6242165298,0.8197673384,-1.0890622575$ $\mathrm{H}, 1.9568524961,2.6482050488,-1.6425499789$ $\mathrm{N},-0.1476656505,0.5714542866,0.2690677245$ $\mathrm{H}, 0.6639942357,-1.5491124001,3.016449994$ $\mathrm{P},-0.571323047,-0.5291751948,1.3220096599$ $\mathrm{N},-1.934526116,0.0731332671,2.0433986669$ $\mathrm{H},-1.9765580191,-2.1863698168,0.5063158664$ $\mathrm{H},-2.0459430116,1.0764071356,2.07692561$ $H, 1.5693714286,-1.0336606173,-2.1303944322$ $\mathrm{N},-0.48967138,0.7148195828,-2.3178238309$ H, 1.3962256455,-0.131116197,2.4635256546 $\mathrm{N}, 1.4584454174,2.2349494586,-0.8654401218$ $\mathrm{H}, 1.0685156651,2.9097612412,-0.222526092$ $\mathrm{N}, 1.8162828836,-0.1640764288,-1.680152853$ $\mathrm{H},-2.3473699701,-0.4181874198,2.8247018367$ $\mathrm{N},-1.0648601157,-2.0581021849,0.9226953522$ $\mathrm{H},-0.3792409031,-2.7505738542,0.6570933002$ $\mathrm{N}, 0.7584439856,-0.8875347931,2.2561963824$ $\mathrm{H},-1.4352689182,1.005679235,-2.1109678687$ $\mathrm{H},-0.2042406782,0.9147691317,-3.2678838701$

$H F=-1073.2974228 \quad \mathrm{NImag}=0$

\section{$32 c$}

Brutoformula: C16H35N7P2

0,1

N,-1.23249004,2.0080155473,-1.1628351257

$P,-0.386057738,1.8650773466,0.2858850884$

$\mathrm{N}, 1.1178292096,2.5006184064,-0.1232470973$

$\mathrm{N},-0.2721307308,0.4986159393,1.055118096$

$\mathrm{N},-1.2875999457,2.8771716929,1.3004331603$

C, $-0.6234030283,1.5663422187,-2.4262284267$

C,-2.6884165455,1.8324640507,-1.1654519841

C, $-1.3371555456,2.6324993447,2.7409551808$

C,-1.5244976436,4.2744543962,0.946973467

C,2.3622643768,1.9808720124,0.4398399941 
C, $1.2892677289,3.7600719382,-0.8430390113$ $P, 0.1680854651,-1.0169731238,0.6490134844$ N,1.3752482649,-1.3991509163,1.776161138 $\mathrm{N}, 0.632945669,-1.1339057299,-0.8525911394$ $\mathrm{N},-1.1258732581,-2.0825476717,1.0181432089$ C,-2.2685735057,-2.0558297659,0.1044075586 C, $-1.5380801175,-2.2449796879,2.409186131$ C,2.1645285487,-2.6126670264,1.5945383968 C, $1.5129339821,-0.7875885563,3.0903925629$ C, $0.8413246273,-2.1852065793,-1.7261034433$ $\mathrm{H}, 0.45512765,1.6941633004,-2.3964948455$ $\mathrm{H},-1.0333689283,2.1703670357,-3.2427327381$ $\mathrm{H},-0.8253714316,0.5087409443,-2.6204093057$ $\mathrm{H},-2.9672190054,0.7866007517,-1.3434258682$ $\mathrm{H},-3.1215650744,2.4414094525,-1.9657839162$ $\mathrm{H},-3.113106379,2.1506119171,-0.2153587459$ $\mathrm{H},-0.7415173736,4.9431204813,1.33229888807$ H,-2.4795532314,4.596631898,1.3751583833 $\mathrm{H},-1.5853645791,4.3929340955,-0.1338125328$ $H,-0.5412562198,3.166638075,3.2803821318$ $\mathrm{H},-1.244503383,1.5671264033,2.9338102294$ $\mathrm{H},-2.3006731931,2.98089688886,3.1280798743$ $\mathrm{H}, 2.782036155,2.6733107946,1.1822094034$ $\mathrm{H}, 3.0972369064,1.8459169353,-0.361228706$ $\mathrm{H}, 2.1972467822,1.0148640769,0.9079161445$ $\mathrm{H}, 1.6180070414,4.5665116108,-0.1739403389$ $\mathrm{H}, 0.3621965971,4.062770007,-1.3259316886$ $\mathrm{H}, 2.0510686339,3.6390986009,-1.6222491717$ $H, 1.2174340407,-1.472757833,3.8994737131$ $H, 0.8997907422,0.1090064013,3.1498174988$ $\mathrm{H}, 2.5597545992,-0.5064082454,3.2640638848$ $H, 3.2110926597,-2.4115033164,1.8512432996$ $\mathrm{H}, 2.1332677277,-2.9404112499,0.5568536874$ H, 1.8104554958,-3.4368757232,2.2311901588 $\mathrm{H},-0.6695350298,-2.3854116448,3.0510697771$ $H,-2.164457078,-3.1387032874,2.4949786799$ $\mathrm{H},-2.1174936735,-1.3864473477,2.784168128$ $\mathrm{H},-2.8216004099,-2.9970604603,0.1872071524$ $\mathrm{H},-1.9242106756,-1.9542849722,-0.9241817463$ $\mathrm{H},-2.9622045702,-1.2312314932,0.331042425$ C, $1.3252431072,-4.2035930336,-3.6778545553$ C, $1.4801150634,-1.8964539812,-2.955145739$ C, $0.4536999635,-3.5299858294,-1.5142937897$ C, $0.6952930441,-4.5115222283,-2.4732045967$ C,1.7152345496,-2.8818139974,-3.9057754772 H, $1.794165704,-0.8740877735,-3.1334352993$ $\mathrm{H},-0.0403142428,-3.7965908472,-0.5877395403$ $\mathrm{H}, 0.3836482088,-5.5321674864,-2.2722719865$ $H, 2.2117295471,-2.6167158751,-4.8342076724$ H,1.5099109757,-4.9722657128,-4.4193948252

$H F=-1697.0861651 \quad \mathrm{NImag}=0$

\section{$32 \mathrm{cH}+$}

Brutoformula: C16H36N7P2(1+) 1,1 $\mathrm{N}, 2.1218585846,1.7859808736,-0.7512794528$ $\mathrm{P}, 1.9642021167,0.4717382527,0.2681101965$
$\mathrm{N}, 2.5169206992,-0.7992002759,-0.6951978264$ $\mathrm{N}, 0.5406394339,0.0886457407,0.8538317318$ $\mathrm{N}, 2.9287211561,0.8158396504,1.5795489283$ C, $1.6604654366,1.7522716141,-2.1467459026$ C,2.2141666678,3.1518035748,-0.2188199874 C,2.4963619156,0.7107459807,2.9763004809 C,4.3639918226,1.0723953616,1.4171745535 C, $2.3114116186,-2.1762136741,-0.2180445203$ C,3.7433905091,-0.6870175572,-1.5034186175 P, $-1.0141490519,-0.0251968067,0.5630248132$ $\mathrm{N},-1.6809484862,-0.9158119004,1.7985405627$ $\mathrm{H},-0.2916917653,-1.0183698534,-1.337786751$ $\mathrm{N},-1.9358808379,1.3633629169,0.5444759049$ C, $-2.0060010479,2.2244444339,-0.6439520398$ C,-2.1270748144,2.114931266,1.7962970068 C,-3.1335994065,-1.0911644946,1.9564747184 C, $-0.9032289673,-1.9489736416,2.4947371542$ C,-2.3037349393,-1.2953639571,-1.61027171 H,1.5542741976,0.7284195845,-2.4978675704 $\mathrm{H}, 2.3890337204,2.2624669237,-2.7838272237$ $\mathrm{H}, 0.6975208102,2.2624320964,-2.2563078271$ $\mathrm{H}, 1.2449271598,3.6623151297,-0.2607556197$ $\mathrm{H}, 2.9276095927,3.7248604447,-0.8175523225$ $\mathrm{H}, 2.5575300806,3.140903496,0.8130023169$ $H, 4.9611315027,0.2265069071,1.7751291786$ $\mathrm{H}, 4.64785856,1.9585050504,1.9934434322$ $\mathrm{H}, 4.6133740047,1.2606643209,0.3742603643$ $H, 3.0052657796,-0.1184082738,3.4801603427$ $\mathrm{H}, 1.423307451,0.5495654054,3.0243122079$ $\mathrm{H}, 2.739481227,1.6369622102,3.5074738083$ $\mathrm{H}, 3.1257251684,-2.5051676027,0.4395110515$ $\mathrm{H}, 2.2794899773,-2.848404298,-1.0793657852$ $\mathrm{H}, 1.3719232347,-2.2606227271,0.3231807174$ H, $4.6220530907,-1.0445041032,-0.95390383$ $\mathrm{H}, 3.9161965581,0.3415918071,-1.8098312651$ H,3.6329413578,-1.2997844815,-2.4021453289 H,-1.2057360943,-1.9673227957,3.5450489529 $H, 0.1574967254,-1.7175681395,2.4469973279$ H, $-1.0804853489,-2.943897152,2.0693650798$ H, $-3.4711234457,-2.0370396998,1.5211989983$ H, $-3.6756071615,-0.2767103387,1.4832952334$ H,-3.3731519372,-1.0928255916,3.0236050839 $\mathrm{H},-2.0621101954,1.4527434292,2.6568428577$ $\mathrm{H},-3.116488976,2.579083641,1.7873827483$ $H,-1.3753021027,2.9056890404,1.9023337755$ $\mathrm{H},-2.9903090683,2.6985263774,-0.6808275309$ $\mathrm{H},-1.8696822049,1.6421321676,-1.5519441516$ H,-1.2497396806,3.0178605758,-0.6067796233 C,-4.4414630752,-2.5359011142,-2.9342461453 C,-2.0885533068,-2.4355737531,-2.3934146291 C,-3.5962375593,-0.7754724316,-1.5010197602 C,-4.6562837809,-1.4038185889,-2.1529895928 C,-3.1493685115,-3.0445367368,-3.0560409778 $\mathrm{H},-1.0878814256,-2.8467510771,-2.4835537721$ $\mathrm{H},-3.7786455678,0.1160328005,-0.916755893$ $\mathrm{H},-5.6546154866,-0.9926602161,-2.0572193991$ $\mathrm{H},-2.9646317787,-3.9234002096,-3.6626362816$ $\mathrm{H},-5.2681775036,-3.0137368683,-3.445292122$ $\mathrm{N},-1.1773666292,-0.6780027152,-0.9852660738$ 
$H F=-1697.5243436 \quad \mathrm{NImag}=0$

\section{4}

Brutoformula: H15N10P3

0,1

N,-1.492691444, $-0.2864477267,-1.8994025724$

$\mathrm{P},-0.6731007682,-0.8751728225,-0.4662816957$

$\mathrm{N},-0.5183885129,-2.450498886,-0.3420511841$

$\mathrm{N},-1.5569907708,-0.1596197427,0.7268122009$

$\mathrm{N}, 0.7990011415,-0.1580259667,-0.6683684866$

P, $-1.7172348316,1.3808070056,0.9918349577$

$\mathrm{P}, 2.2484616362,-0.7483296447,-0.5153932947$

$\mathrm{H},-1.3162377866,-2.9190309756,0.072698012$

$\mathrm{N},-0.4615971976,2.3246074499,1.6242138304$

$\mathrm{N},-2.8293488366,1.5356311238,2.2373059132$

$\mathrm{N},-2.1412923339,2.229612111,-0.387606586$

$\mathrm{N}, 3.0459812343,-0.5772514379,-1.9928085566$

$\mathrm{N}, 2.2365196382,-2.2540340973,0.1741705464$

$\mathrm{N}, 3.3808758183,0.0606923296,0.4331760187$

$\mathrm{H},-0.9383492247,-0.4814583408,-2.7280913386$

$H,-2.3826695611,-0.7671543128,-2.0089942352$

$\mathrm{H},-3.2348891892,2.4527156117,2.3711695067$

$\mathrm{H},-3.5278352218,0.8039938717,2.2383097331$

$\mathrm{H},-0.2123757554,2.0664170375,2.5723956195$ $\mathrm{H}, 0.3598972937,2.3137337936,1.0280703786$ $H,-1.8411315657,3.1905007189,-0.4724272132$ $\mathrm{H},-2.0211391888,1.6722993331,-1.2367754691$ $H, 3.5973951223,1.0067625663,0.1473390362$ H,3.2274458887,-0.0164910699,1.430002109 $\mathrm{H}, 3.0509004432,-2.8479678932,0.115255741$ $H, 1.3065699719,-2.7091233246,0.0702133152$ H,3.9915120822,-0.931253303,-2.0584250974 $H, 2.4885259591,-0.8023490865,-2.8051211228$

$H F=-1581.0099606 \quad \mathrm{NImag}=0$

\section{$34 \mathrm{H}+$}

Brutoformula: H16N1OP3(1+)

1,1

$H, 1.4364627051,2.9699313676,0.4893986653$ $\mathrm{P}, 0.1065021262,1.0718454753,0.4337784745$ $\mathrm{N}, 1.0365089509,2.3280818827,-0.1858533041$ $\mathrm{N}, 0.758919185,0.267205541,1.6435104153$ N,-1.223980686,1.8695356992,1.0797486049 P, 1.2987144381,-1.17858446679,1.9877199583 $\mathrm{N}, 0.9187168471,-2.2238255423,0.7540473922$ $\mathrm{H}, 0.9411992714,-1.6341252317,4.2255192578$ $\mathrm{N}, 2.889886728,-1.0086418166,2.4247762557$ $\mathrm{H},-0.1911483334,-2.4186392128,3.2413293101$ $\mathrm{H}, 1.7166624674,2.0590191017,-0.8859080148$ $\mathrm{N},-0.2478670411,0.119038278,-0.82045367$ H,3.4238936683,-1.8045245953,2.7436593289 $H, 3.4333468873,-0.2758818641,1.9942753405$ $H, 1.3128322096,-3.1536275587,0.7274449844$ $\mathrm{H}, 0.7249969643,-1.7968404429,-0.1467944469$ $\mathrm{N}, 0.7273263758,-2.0023874786,3.3083326629$
$\mathrm{H},-1.3503301238,1.7549666379,2.0764247531$ H, $-1.3901859266,2.817381196,0.7671938116$ P, $-1.2072463028,0.2260795175,-2.0803640015$ N,-2.5066976741, 1.1954981392,-1.7134922318 $\mathrm{N},-1.4740614426,-1.3460023164,-2.5500587002$ $\mathrm{N},-0.7387081955,0.8821116441,-3.5332809203$ $\mathrm{H},-2.0482061598,-1.5192884599,-3.3641939164$ $\mathrm{H},-1.5894819243,-2.0335996395,-1.8189751659$ $\mathrm{H},-0.6722884724,1.8886347552,-3.5984969432$ $\mathrm{H},-0.0377608225,0.3923414996,-4.07267576$ $\mathrm{H},-2.794026036,1.236554185,-0.7434395218$ $\mathrm{H},-3.2539796824,1.3177437067,-2.3831726167$

$H F=-1581.4616383 \quad N I m a g=0$

\section{7}

\section{Brutoformula: H15N10P3}

0,1

H,-1.7765739438,-2.3448969343,2.8494939195

P, $-1.3052139703,-1.323299029,0.8500387683$

$\mathrm{N},-2.8568764696,-0.8615571304,0.3683112264$ $\mathrm{N},-0.546780688,-0.0176548066,1.3927022797$ $\mathrm{N},-1.5062821953,-2.6257725002,1.9125384834$ $\mathrm{P},-1.1419465292,1.0398670111,2.4827166169$ N, $-0.6914492078,0.363917927,3.9915696692$ N, $-2.6856745977,1.3090024773,2.2941405035$ $\mathrm{N},-0.2379634084,2.4884257316,2.4301981333$ $\mathrm{H},-3.5309541771,-1.618157929,0.3436962316$ H, $-3.1860901388,-0.0623083174,0.9342632845$ $\mathrm{N},-0.5154174998,-2.020635271,-0.3896025827$ $\mathrm{H}, 0.766902327,2.3910689559,2.5223732774$ $\mathrm{H},-0.4686215827,3.0723140273,1.6348776768$ $\mathrm{H}, 0.2560229581,0.0061661873,4.0320359378$ $\mathrm{H},-0.8927524921,0.9422435167,4.7991823989$ H,-3.1090766771,2.0091679566,2.8914415546 $\mathrm{H},-0.7042702829,-3.2441459436,1.9378196671$ $\mathrm{P}, 0.0367469913,-1.171346418,-1.602988787$ $\mathrm{N}, 0.7050777122,-2.2721633386,-2.6705447861$ $\mathrm{N}, 1.3156062867,-0.0901418165,-1.4305779707$ $\mathrm{N},-1.1609780877,-0.2186215795,-2.2747264804$ $\mathrm{H}, 1.1308384585,0.5745007671,-0.6826682968$ $\mathrm{H}, 2.2035684538,-0.5527847021,-1.2708195656$ $H,-2.0340623178,-0.2082106822,-1.7513850892$ $\mathrm{H},-0.9036395963,0.6754504499,-2.6674174933$ $\mathrm{H}, 0.2375643797,-3.1694423225,-2.6642485474$ $H, 0.8818860991,-1.9407552177,-3.6100013557$

$H F=-1581.0168742 \quad \mathrm{NImag}=0$

\section{$37 \mathrm{H}+$}

Brutoformula: H16N10P3(1+) 1,1 $H, 1.4364627051,2.9699313676,0.48939866653$ $\mathrm{P}, 0.1065021262,1.0718454753,0.4337784745$ $\mathrm{N}, 1.0365089509,2.3280818827,-0.1858533041$ $\mathrm{N}, 0.758919185,0.267205541,1.6435104153$ $\mathrm{N},-1.223980686,1.8695356992,1.0797486049$ 
$\mathrm{P}, 1.2987144381,-1.1785844679,1.9877199583$ N,0.9187168471,-2.2238255423,0.7540473922 $\mathrm{H}, 0.9411992714,-1.6341252317,4.2255192578$ $\mathrm{N}, 2.889886728,-1.0086418166,2.4247762557$ $\mathrm{H},-0.1911483334,-2.4186392128,3.2413293101$ $H, 1.7166624674,2.0590191017,-0.8859080148$ $\mathrm{N},-0.2478670411,0.119038278,-0.82045367$ $\mathrm{H}, 3.4238936683,-1.8045245953,2.7436593289$ $\mathrm{H}, 3.4333468873,-0.2758818641,1.9942753405$ $\mathrm{H}, 1.3128322096,-3.1536275587,0.7274449844$ $\mathrm{H}, 0.7249969643,-1.7968404429,-0.1467944469$ $\mathrm{N}, 0.7273263758,-2.0023874786,3.3083326629$ $\mathrm{H},-1.3503301238,1.7549666379,2.0764247531$ H, $-1.3901859266,2.817381196,0.7671938116$ P. $-1.2072463028,0.2260795175,-2.0803640015$ $\mathrm{N},-2.5066976741,1.1954981392,-1.7134922318$ $\mathrm{N},-1.4740614426,-1.3460023164,-2.5500587002$ $\mathrm{N},-0.7387081955,0.8821116441,-3.5332809203$ $\mathrm{H},-2.0482061598,-1.5192884599,-3.3641939164$ $\mathrm{H},-1.5894819243,-2.0335996395,-1.8189751659$ $\mathrm{H},-0.6722884724,1.8886347552,-3.5984969432$ $\mathrm{H},-0.0377608225,0.3923414996,-4.07267576$ $\mathrm{H},-2.794026036,1.236554185,-0.7434395218$ H,-3.2539796824,1.3177437067,-2.3831726167

$H F=-1581.4616383 \quad$ NImag $=0$

\section{8}

Brutoformula: H19N13P4

0,1

$\mathrm{N}, 1.766660965,-1.1385529121,-0.6756274884$ $\mathrm{P}, 0.8361749736,0.2000677036,-0.9414350042$ $\mathrm{N}, 1.6453190928,1.5900040804,-0.9153574953$ $\mathrm{N},-0.3716457981,0.2853309656,0.2355067769$ $\mathrm{N},-0.0028485193,-0.1191860952,-2.358981646$ P, $-0.1422260373,0.9129995058,1.670073712$ $H, 2.5592508755,1.5130198278,-1.3527452964$ P.1.2554248455,-2.6190585663,-0.795793149 P, $-0.9701048124,0.9468004456,-3.0044749983$ $\mathrm{N}, 0.5617148673,2.4202574613,1.5746210227$ $\mathrm{N}, 0.7483365059,0.1099029682,2.8745553376$ $\mathrm{N},-1.6356455152,0.9090220135,2.4414726857$ $\mathrm{N},-1.5338724642,0.6629904286,-4.5559021131$ $\mathrm{N},-0.1958121443,2.4171916982,-3.1824178853$ N.-2.4301272064,0.9715187153,-2.160187414 $\mathrm{N}, 0.8612897009,-3.0012244695,-2.3809458805$ $\mathrm{N}, 0.0512472383,-2.9216117186,0.3502824018$ N.2.3357009997,-3.848453591,-0.4354235764 $\mathrm{H}, 0.3976794776,-0.8195115871,3.0817893777$ $H, 1.7365593824,0.0559373819,2.6510848288$ $\mathrm{H}, 1.0433695454,2.7650471283,2.3950307448$ H,1.1210142474,2.4747201555,0.6981527725 $\mathrm{H},-1.6524477295,1.329495825,3.3619496001$ $\mathrm{H},-2.4001604676,1.2360112286,1.8663761001$ $H, 0.5176412626,2.5421191904,-2.4493825311$ $\mathrm{H},-0.7454769462,3.2432699658,-3.3779480214$ $H,-2.2670245445,0.8053986993,-1.1689170838$ H, $-3.0712806364,1.7355265868,-2.3337833624$
$\mathrm{H},-0.8250675295,0.6976293551,-5.2771850626$ $\mathrm{H},-2.142437314,-0.1393480085,-4.6517380274$ $H,-0.4844912466,-3.7761894431,0.2611156903$ $\mathrm{H},-0.5375619219,-2.1015910506,0.4913237928$ H,3.1146645618,-3.9120923,-1.07910037 $\mathrm{H}, 2.6468951126,-3.8617957522,0.5275797596$ $\mathrm{H}, 0.4380463221,-2.1908946043,-2.838994422$ $H, 0.368412058,-3.867599489,-2.555904859$

$H F=-2089.1629938 \quad N I m a g=0$

$38 \mathrm{H}+$

Brutoformula: H20N13P4(1+) 1,1

$\mathrm{N}, 1.6541606631,-1.4589768435,-0.0923996236$ $\mathrm{P}, 1.1353706616,0.0407409388,-0.3588949155$ $\mathrm{H}, 1.9900651499,-4.4876234814,1.6985724588$ $\mathrm{N}, 0.3354545845,0.5855897088,0.9520035666$ $\mathrm{N}, 0.2923773785,0.2255567483,-1.735656121$ $P, 0.1718655526,1.9715067816,1.6946089474$ $\mathrm{N}, 2.5269555877,0.9891442164,-0.6165253514$ $P, 0.9965750092,-2.7916386842,0.4266610017$ P, $-1.2033591632,0.5450549524,-2.0843508834$ $\mathrm{N}, 1.603714026,2.8143666547,1.6546561502$ $\mathrm{N},-0.1752639694,1.9626217286,3.3199642193$ N,-1.2018976611,2.7482107628,1.1271777864 $\mathrm{N},-1.5322860518,-0.236519457,-3.5129923462$ $\mathrm{N},-1.4299325813,2.2254953062,-2.0702549072$ $\mathrm{N},-2.5242804732,0.1114900755,-1.160865629$ $\mathrm{N}, 2.1671906823,-3.5761349691,1.3023900059$ $\mathrm{N}, 0.5336916196,-4.0305970387,-0.5896624426$ $\mathrm{N},-0.4682700503,-2.452532593,1.1634246637$ H, $-1.0867169484,1.6329611104,3.6065131876$ $H, 0.5682381673,1.6825259548,3.9450693816$ $\mathrm{H}, 1.645488148,3.7618081742,2.0039069542$ $\mathrm{H}, 2.2009313976,2.6161106841,0.8552076117$ $H,-1.4595082837,3.6223146713,1.5695749213$ H.-1.3066415488,2.774343092, 0.1148405318 $\mathrm{H},-0.6704808466,2.7430132659,-2.4985968512$ $\mathrm{H},-2.3299293951,2.5602496776,-2.3995053917$ $\mathrm{H},-2.5846193954,0.5400831454,-0.2444604283$ $\mathrm{H},-2.7293473254,-0.8790832138,-1.1281903578$ $\mathrm{H},-2.3914069836,-0.0454201406,-4.0100811689$ $\mathrm{H},-0.7416841431,-0.44212922,-4.1072801398$ H, $-0.2890165596,-3.8749034113,-1.1559964782$ $\mathrm{H}, 1.2741459886,-4.4954364938,-1.0991385161$ $\mathrm{H},-0.9384799958,-3.1832677029,1.6815709983$ $\mathrm{H},-0.5157840373,-1.5347729329,1.5970299654$ $\mathrm{H}, 2.84844042,-3.0172946655,1.7933515127$ $H, 2.675110301,1.1732811669,-1.602861788$ $\mathrm{H}, 3.3607404896,0.5568770123,-0.2304191315$

$H F=-2089.6200481 \quad N I m a g=0$

41

Brutoformula: C1H5N3

0,1 
$\mathrm{N}, 0.1012491464,-0.5790334561,-1.4346080986$ $\mathrm{C}, 0.0209236792,-0.6456721781,-0.0463602606$ $\mathrm{N},-0.0865267516,0.6186989291,0.5398211864$ $\mathrm{N}, 0.0599709273,-1.7780065581,0.5472016656$ $\mathrm{H},-0.1292396787,-1.6905316079,1.5431204917$ $H, 0.6732635517,0.1704593282,-1.7992408808$ $\mathrm{H}, 0.3168796151,-1.4772717792,-1.8439529297$ $\mathrm{H},-0.6308106213,1.2926658147,0.0184262272$ $\mathrm{H},-0.3081802431,0.6148897035,1.5241472048$

$H F=-205.4462479 \quad \mathrm{NImag}=0$

\section{$41 \mathrm{H}+$}

Brutoformula: $\mathrm{C} 1 \mathrm{H} 6 \mathrm{~N} 3(1+)$

1,1

$\mathrm{N}, 0.2432745651,-0.6271798383,-1.3942009745$ C, $-0.093567031,-0.618173796,-0.1024755103$ $\mathrm{N},-0.2554786699,0.5424505292,0.5370138823$ $\mathrm{H},-0.6846486421,0.5849815197,1.4490602924$ $\mathrm{N},-0.2687002211,-1.7698583353,0.5494792378$ $\mathrm{H}, 0.2017274146,0.2109366022,-1.9542237223$ $\mathrm{H}, 0.5525153249,-1.4718938816,-1.8509607023$ $\mathrm{H}, 0.04689355558,1.4140625787,0.1287843197$ $\mathrm{H},-0.3393067736,-1.799146078,1.5554376294$ $\mathrm{H},-0.3356709356,-2.6477908736,0.0569515186$

$H F=-205.8355535 \quad \mathrm{NImag}=0$

\section{2}

Brutoformula: $\mathrm{C} 3 \mathrm{H} 5 \mathrm{~N} 3$

0,1 $\mathrm{N}, 0.6025439971,-0.522358043,-1.4760185115$ C, $0.001736342,-0.3572178576,-0.2275491763$ $\mathrm{N},-0.3856092368,0.6802625813,0.4234512965$ $\mathrm{H},-0.5203367386,-1.8632729552,1.1323936608$ C, $0.3909579438,-2.5761418598,-0.6855759217$ $\mathrm{N},-0.1138491284,-1.6602453242,0.2357861967$ $\mathrm{H}, 0.8239735857,0.2444833922,-2.0859293053$ C, $0.8349212498,-1.8766648429,-1.7476075628$ $\mathrm{H},-0.2117736855,1.5390255236,-0.0899628992$ $\mathrm{H}, 0.3885059546,-3.636479894,-0.5046433796$ $\mathrm{H}, 1.2909680202,-2.2111670364,-2.6625225417$

$H F=-281.6465132 \mathrm{NImag}=0$

\section{$42 \mathrm{H}+$}

Brutoformula: $\mathrm{C} 3 \mathrm{H} 6 \mathrm{~N} 3(1+)$

1,1

$\mathrm{N}, 0.5689560157,-0.5596226414,-1.4696115305$ $\mathrm{C}, 0.1165694136,-0.4500590909,-0.2070545742$ $H, 1.1198266182,-2.2187907699,-2.7545865602$ $\mathrm{H},-0.2964816361,-1.9403318341,1.208230038$ C, $0.417385398,-2.6215639389,-0.6990765136$ $\mathrm{N}, 0.0181504812,-1.7011762586,0.2785888648$ $\mathrm{H}, 0.7448996283,0.215648762,-2.0928367729$ C, $0.7606568247,-1.9101157181,-1.7886842112$
$\mathrm{N},-0.1792262095,0.6842597393,0.4404746461$ $\mathrm{H}, 0.4141744995,-3.6814005841,-0.5147407171$ $\mathrm{H},-0.073768995,1.583580051,-0.0017939495$ $\mathrm{H},-0.5091037656,0.6740307175,1.3926206432$

$H F=-282.0436689 \mathrm{~N} / \mathrm{mag}=0$

43

Brutoformula: $\mathrm{C} 3 \mathrm{H} 7 \mathrm{~N} 3$

0,1

$\mathrm{H},-2.0722587452,-0.1935229161,-0.6448891895$

C, $-0.0848891194,-0.188323497,-1.1115585411$ $\mathrm{N}, 1.0242341739,0.0688209601,-0.2922007818$ $\mathrm{N},-0.1801071338,-0.2190662598,-2.3849679116$ C, $-0.8254267556,0.0076802988,1.0990300598$ $\mathrm{N},-1.1631532807,-0.4017965581,-0.2600949852$ $\mathrm{H}, 1.2192850515,0.4289732569,1.7930723565$ C, $0.6925378681,-0.2320102932,1.1027073983$ $\mathrm{H},-1.0474708371,1.0678398516,1.2834210301$ $H, 0.7177716084,-0.0473643975,-2.8304576688$ $\mathrm{H},-1.3449097815,-0.5963097686,1.8448868798$ $H, 0.9161134522,-1.2743979771,1.3652836886$ $\mathrm{H}, 1.9213406652,-0.227765254,-0.6467994542$

$H F=-282.8673141 \quad N I m a g=0$

$43 \mathrm{H}+$

Brutoformula: C3H12N6P1(1+) 1,1

$\mathrm{N}, 0.1682267346,-2.2609266303,0.9463781561$ P, $-1.2392715283,-1.3487181917,0.8821696289$ $\mathrm{N},-1.391120901,-0.9604086442,2.4848208889$ $\mathrm{H}, 2.2003420406,2.2209972653,-0.031634721$ $\mathrm{N},-1.1232484219,-0.240561599,-0.2693621258$ $\mathrm{N},-2.6688810744,-2.0843698477,0.549746047$ C, $-0.0895071488,0.4916573812,-0.6333444719$ $\mathrm{H}, 0.230712329,-2.9654966856,1.6735604082$ $\mathrm{H}, 0.509213247,-2.6169697035,0.0603178605$ $\mathrm{H},-2.2544159825,-0.5235253752,2.7805247391$ $\mathrm{H},-0.581627516,-0.6460148443,3.0025650463$ $\mathrm{N}, 1.2220195448,0.3614600667,-0.3123074446$ $\mathrm{N},-0.223102675,1.5401433215,-1.4705052037$ $\mathrm{H}, 1.5301834367,-0.2568255837,0.4225893323$ C, $2.014644597,1.4897932957,-0.8237666934$ C, $1.0765379538,2.0559347082,-1.9130485047$ $\mathrm{H},-1.0896995299,1.6852108098,-1.9653215695$ $H, 1.0829618968,3.1445711767,-1.942559487$ H,1.3295904759,1.6698300542,-2.905115318 $H, 2.9679909327,1.1522372259,-1.2279412367$ $\mathrm{H},-3.0245488351,-2.8375222424,1.1200078273$ $\mathrm{H},-3.0599063692,-2.0018317105,-0.3771071902$

$H F=-791.4353487$ NImag=0

\section{4}

Brutoformula: $\mathrm{C} 5 \mathrm{H} 11 \mathrm{~N} 3$ 
0,1

$\mathrm{N},-1.1537530449,-0.0705521717,-0.3725683984$

C, $-0.0517428742,0.2671835786,-1.1510188672$ $\mathrm{N}, 1.0597773748,0.3146517516,-0.2979515457$

$\mathrm{N},-0.1327294416,0.4900073981,-2.4098733589$ C, $-0.8075432521,0.0094194428,1.0380743741$ C, $-2.4919927604,0.2638094225,-0.8148439251$ C, $2.3964259166,0.0920106696,-0.8076170662$ C, $0.6982557148,-0.2560982891,0.996597253$ $\mathrm{H},-1.0207585368,1.0090859699,1.4497902371$ $\mathrm{H}, 0.7757409729,0.6803851474,-2.8206190775$ $\mathrm{H},-1.3538732921,-0.7315147547,1.626511486$ $H, 1.2408341572,0.2301745036,1.8105847609$ $\mathrm{H}, 0.9070136342,-1.3369855334,1.0305674038$ H, $-3.213901975,-0.4052877226,-0.3398810813$ $\mathrm{H},-2.539821473,0.1393603629,-1.8951997805$ $\mathrm{H},-2.7585821238,1.3031980093,-0.570663032$ $H, 3.1236423406,0.3788607844,-0.0450745475$ $\mathrm{H}, 2.5751326243,0.7191884915,-1.6825811366$ $\mathrm{H}, 2.5752507897,-0.9577379799,-1.0865070458$

$H F=-361.5050877 \quad N I m a g=0$

\section{$44 \mathrm{H}+$}

Brutoformula: C5H12N3(1+)

1,1

$\mathrm{N},-0.9163517376,-0.673501352,0.0768355763$ C, $0.0973693241,-0.351372629,0.8925101293$ $\mathrm{N}, 0.0525690389,0.9342138268,1.2704762032$ $\mathrm{N}, 1.0420343871,-1.2111020224,1.2842119778$ $\mathrm{H}, 1.7393779873,-0.9480092658,1.9612518824$ $\mathrm{H}, 1.0862599766,-2.1448421165,0.9100011977$ C,-1.0156406138,-1.9006693379,-0.7058097806 C,- $-1.6500507412,0.5532471776,-0.2922385432$ C, $0.8384584782,1.5251945199,2.3484137845$ C, $-1.218422553,1.529248384,0.8126602947$ $\mathrm{H},-1.9364810308,1.5586217277,1.6388533657$ $\mathrm{H},-2.7234809226,0.3676956107,-0.2999502727$ $\mathrm{H},-1.3365958611,0.8919986421,-1.2852265343$ $\mathrm{H},-1.0547650607,2.5415153823,0.4449108333$ $\mathrm{H},-0.3663858419,-1.8780684656,-1.5871219496$ $\mathrm{H},-2.0485160397,-2.016659089,-1.0316911382$ $\mathrm{H},-0.7741914508,-2.7675931607,-0.0881607962$ $\mathrm{H}, 0.4486767537,1.2535750199,3.3348524336$ $H, 0.8056392932,2.6087447251,2.2421536729$ $H, 1.8848865599,1.2258831579,2.2668496176$

$$
\mathrm{HF}=-361.9093677 \mathrm{Nlmag}=0
$$

\section{5}

Brutoformula: $\mathrm{C} 5 \mathrm{H} 13 \mathrm{~N} 3$

0,1

$\mathrm{N}, 0.3107143105,-0.9666862259,-0.6729527352$ C, $-0.6229894647,-0.2681047411,0.0953688104$ $\mathrm{N},-0.1459642243,0.9559504147,0.6021881156$ $\mathrm{N},-1.7979529641,-0.75776424333,0.2724253333$ H, $-2.3175644923,-0.2438282204,0.97829354$
C, $1.0474820415,-0.2506845519,-1.7133506269$ C,- $-0.0570355146,-2.3238149746,-1.0600673772$ C, $1.137955731,0.9675249445,1.3042883101$ C,-1.1255920445,1.8601699745,1.1804551099 $\mathrm{H}, 2.0022880521,-0.7503986299,-1.8996525972$ $\mathrm{H}, 1.2404306753,0.775313228,-1.4096417626$ $\mathrm{H}, 0.4824759751,-0.2283565751,-2.6575842202$ $H, 0.8422272067,-2.8403464233,-1.4059509245$ $\mathrm{H},-0.8078266815,-2.3385521698,-1.8616393082$ $\mathrm{H},-0.4738292802,-2.8510142685,-0.2045190907$ $\mathrm{H},-0.6736141401,2.8496273409,1.2823553429$ $\mathrm{H},-1.4702316535,1.5441851426,2.1788456406$ $\mathrm{H},-1.9915478337,1.9470110051,0.5228836216$ $H, 1.5996953279,1.9556809174,1.2199214899$ $H, 1.8082732164,0.2270708312,0.8749524653$ $\mathrm{H}, 1.0126057548,0.737017226,2.3733808622$

$H F=-362.699836 \quad \mathrm{NImag}=0$

\section{$45 \mathrm{H}+$}

Brutoformula: $\mathrm{C} 5 \mathrm{H} 14 \mathrm{~N} 3(1+)$ 1,1 $\mathrm{N}, 0.258541579,-0.9023079941,-0.749904627$ C, $-0.54078754,-0.2410902394,0.1044409002$ $\mathrm{N},-0.122695655,0.8557427773,0.7590302024$ $\mathrm{H}, 1.2793706497,1.241207238,2.261177522$ $\mathrm{N},-1.7946950137,-0.6895297,0.310296809$ C, $1.2652889958,-0.2165826722,-1.576299136$ C, $0.0049966375,-2.3056892988,-1.1066844542$ C,1.2738996791,1.0310237272,1.1894651289 C,-1.0760956772,1.8291003836,1.3109296463 $\mathrm{H}, 2.2771361963,-0.5234577523,-1.3033170637$ $H, 1.1701531891,0.8613667303,-1.4754973327$ $H, 1.0896622276,-0.4801755293,-2.6215538764$ $\mathrm{H}, 0.9626461408,-2.7837206516,-1.3143765379$ $\mathrm{H},-0.619960048,-2.3882808753,-2.0022229326$ $\mathrm{H},-0.4637374939,-2.8316503486,-0.276394938$ $\mathrm{H},-0.6139347671,2.8161032563,1.279108301$ $\mathrm{H},-1.3276647709,1.602246811,2.3523408501$ $\mathrm{H},-1.9821980711,1.8592391036,0.7077343949$ $\mathrm{H}, 1.7478156585,1.8647409039,0.6670639181$ $\mathrm{H}, 1.8423067068,0.1206415263,1.0173620645$ $\mathrm{H},-2.3151149021,-0.4291939129,1.1325967287$ $H,-2.2486504522,-1.297132763,-0.3527083555$

$H F=-363.1073233 \quad \mathrm{NImag}=0$

46

Brutoformula: $\mathrm{C} 3 \mathrm{H} 9 \mathrm{~N} 7$ 0,1 C, $0.6835766332,0.7060071368,-0.2238229745$ $\mathrm{N}, 1.1976842067,1.5459306727,-1.070289297$ $H, 1.8908554749,2.1164574156,-0.5932087135$ $\mathrm{N},-0.2981500909,-0.220374797,-0.5903761605$ $\mathrm{N}, 1.1392916292,0.7108705346,1.0911546779$ C, $-0.8016627283,-0.2405934167,-1.8010797818$ C, $0.6572886774,-0.0067704155,2.0591344104$ 
$\mathrm{N},-1.8520812471,-1.1095055507,-2.0430877873$ $\mathrm{N},-0.4015476028,0.5193945878,-2.8405333198$ $\mathrm{N},-0.4676506206,-0.7870804836,2.0513885751$ $\mathrm{N}, 1.3387417872,0.0158960956,3.2652064792$ $\mathrm{H},-1.92388944732,-1.4852770702,-2.9772387486$ $\mathrm{H},-1.9914946016,-1.7930087396,-1.3147647581$ $\mathrm{H}, 2.0500282136,0.7317299235,3.297942003$ $\mathrm{H}, 0.777267675,-0.0502205426,4.1021615249$ $H, 0.306711872,1.2251078855,-2.5759269362$ $\mathrm{H},-1.0043733072,0.6326674483,-3.6395377446$ $\mathrm{H},-0.4906444984,-1.5607131943,2.6988629057$ $\mathrm{H},-0.8099519991,-0.9505174893,1.1040156467$

$H F=-503.188208$ NImag=0

\section{$46 \mathrm{H}+$}

Brutoformula: C3H10N7(1+) 1,1

C, $0.3850812234,0.9161115448,-0.1189021946$ $\mathrm{H},-0.7756147765,-1.0501893783,1.0959486861$ $\mathrm{N}, 0.8153964966,1.9415643902,-0.9078110326$ $\mathrm{N},-0.574732983,0.0611131397,-0.5423889073$ $\mathrm{N}, 0.9725466074,0.8650186998,1.070933005$ C, $-0.819259299,-0.2442485653,-1.8087392913$ C, $0.7211265925,-0.0559001074,2.0081628365$ $\mathrm{N},-2.0061795368,-0.8128720288,-2.0904433641$ $\mathrm{N}, 0.0460042606,-0.0650301377,-2.8331618999$ $\mathrm{N},-0.2113300135,-1.0154650079,1.9370618715$ N,1.4815892533,0.0276774746,3.1128494296 $\mathrm{H},-2.2526421586,-1.1373980156,-3.0113172581$ $\mathrm{H},-2.6973254891,-0.8715263051,-1.3602144711$ $\mathrm{H}, 2.1636743795,0.7678317478,3.1602244318$ $\mathrm{H}, 1.3854970362,-0.5991447646,3.8948413386$ $\mathrm{H}, 0.9947852792,0.2176662701,-2.6411704071$ $\mathrm{H},-0.1444753071,-0.4379759924,-3.7504010511$ $\mathrm{H},-0.3905675559,-1.6454454894,2.7028432663$ $H, 0.2342641318,2.2809200104,-1.6594145411$ $H, 1.4182366128,2.617110558,-0.4593243341$

$$
H F=-503.6057843 \quad \mathrm{NImag}=0
$$

\section{7}

\section{Brutoformula: $\mathrm{C} 11 \mathrm{H} 25 \mathrm{~N} 7$}

\section{0,1}

$\mathrm{H},-2.3193010274,-1.241310383,-0.5619379702$ $\mathrm{N},-2.0441179107,-0.7244172605,0.2723660169$ C, $-1.105586357,0.113498376,-0.0149773065$ $\mathrm{N},-0.5696080214,0.3497326206,-1.2846150851$ $\mathrm{N},-0.6865162516,1.0762504862,0.8959656922$ $\mathrm{C}, 0.0529462482,0.9728298784,1.936019521$ C, $-0.2122273378,-0.5642912944,-2.1239692646$ $\mathrm{N}, 0.4773608823,-0.2047201971,2.5588581122$ $\mathrm{N}, 0.5700519924,2.1491491226,2.4941646023$ $\mathrm{N}, 0.2111916847,-1.8555855405,-1.8288953041$ $\mathrm{N},-0.2012255854,-0.2556490676,-3.4823575708$ C, $0.4634905404,3.3641433783,1.6941005423$ C, $0.3605139227,2.3836381206,3.9216133077$
C,1.7800990783,-0.3039252355,3.1971950517 C, $-0.4689838004,-1.2516600915,2.9297135772$ C, $0.9836993014,-0.5574576137,-4.2834236064$ C, $-0.8800261901,0.9686554226,-3.891143128$ C, $-0.1867156039,-2.9969984737,-2.64450748$ C, $0.724858607,-2.2010586087,-0.5148081283$ $\mathrm{H},-0.5537990251,3.777740856,1.6990607868$ $\mathrm{H}, 0.7300287255,3.1487216666,0.6615193136$ $H, 1.1511409523,4.1095851405,2.1038019354$ $\mathrm{H},-0.5976105577,2.8931078422,4.1014562027$ $H, 1.162336863,3.011432161,4.3209541611$ $H, 0.3507686725,1.4453175936,4.4716822226$ $\mathrm{H}, 1.7206438864,-0.2662030551,4.2953535623$ $\mathrm{H}, 2.4267685,0.5031799082,2.8583057032$ $H, 2.2407099886,-1.2623161487,2.9295811368$ $\mathrm{H},-0.6589328607,-1.2303361486,4.0140741593$ $\mathrm{H},-0.0586688566,-2.2376631265,2.6836645023$ $\mathrm{H},-1.4013473343,-1.126777639,2.3844258827$ $H, 0.6940007029,-0.7918124369,-5.3119022422$ $\mathrm{H}, 1.520762822,-1.4075709002,-3.8699014087$ $H, 1.6683180846,0.3027843716,-4.3077176076$ $\mathrm{H},-1.0807831779,0.9124722744,-4.964533321$ $\mathrm{H},-0.2757435495,1.8623687106,-3.6876781997$ $\mathrm{H},-1.8190495701,1.0696931167,-3.3516968601$ $\mathrm{H}, 0.6828372924,-3.5978664656,-2.9369683119$ $\mathrm{H},-0.6980453663,-2.6571906335,-3.5422136605$ H, $-0.8694188536,-3.6454401815,-2.0791472829$ $H, 1.1286651036,-1.3172063247,-0.0235813612$ $\mathrm{H}, 1.5309770044,-2.9330638748,-0.6345546384$ $\mathrm{H},-0.0476264042,-2.6292106181,0.134669534$

State $=1-\mathrm{A} \quad \mathrm{Nlmag}=0$

\section{$47 \mathrm{H}+$}

Brutoformula: $\mathrm{C} 11 \mathrm{H} 26 \mathrm{~N} 7(1+)$ 1,1 $\mathrm{H},-1.3232858731,-3.0751455208,-0.5202885558$ $\mathrm{N}, 0.4968659204,2.3588480968,-0.5858010756$ C, $0.374186141,1.0007425533,-0.5534119877$ $\mathrm{N}, 0.7159731485,0.3994827474,-1.691906354$ $\mathrm{N}, 0.0452836346,0.3222178941,0.5620899093$ C, $-0.3663767979,0.8626695282,1.7085260754$ C, $0.5429674433,-0.9042683893,-1.9403239965$ $\mathrm{N},-1.2262365798,1.926756431,1.807871081$ $\mathrm{N}, 0.0626666595,0.2882339961,2.8606871496$ $\mathrm{N},-0.6368187689,-1.5598018748,-1.7786661065$ $\mathrm{N}, 1.585145753,-1.5807281271,-2.4776805508$ C, $1.2431545919,-0.5780640045,2.8460373352$ C, $-0.7905676429,0.138861355,4.0443765149$ C,-2.2444126416,2.2051414157,0.7950159339 C,-1.2097937141, 2.8678198655,2.9324077166 C,2.9380251388,-1.0263706337,-2.3877078053 C, $1.4225031281,-2.636331039,-3.4830144096$ C, $-1.9070898209,-0.8465522357,-1.7246854413$ C, $-0.7176217162,-2.9788162378,-1.4260340648$ $\mathrm{H}, 1.720009555,-0.5291486066,3.8268949988$ $\mathrm{H}, 1.9468522284,-0.2416321611,2.0898380894$ $\mathrm{H}, 0.9700007417,-1.6169758084,2.6351225076$ 
$\mathrm{H},-0.3899413977,0.6817595619,4.9044922324$

$\mathrm{H},-0.8445455177,-0.9221799512,4.3030882204$

$\mathrm{H},-1.7992102533,0.48675619,3.8370997472$

H,-3.2119625942,2.329610563,1.2894621637

$\mathrm{H},-2.3144286474,1.3765780821,0.0965880098$

$\mathrm{H},-2.0175472475,3.1168675878,0.2353722686$

H, $-2.0806233757,2.7505652633,3.5843394704$

$\mathrm{H},-1.2246914195,3.8861890317,2.5331374677$

$\mathrm{H},-0.3033718617,2.7413724547,3.5201694514$

$H, 3.6505483744,-1.8533531631,-2.375135145$

$\mathrm{H}, 3.0484534042,-0.4476818388,-1.4751562818$

$\mathrm{H}, 3.1565413086,-0.3804583,-3.2439031996$

$H, 1.7652409551,-3.6063857024,-3.1133473159$

$\mathrm{H}, 2.0183711422,-2.3729285125,-4.3608032057$

$\mathrm{H}, 0.3826476379,-2.7144782816,-3.7904874451$

$\mathrm{H},-2.6456485761,-1.3968246728,-2.313531399$

$\mathrm{H},-1.7968414258,0.1479046378,-2.152148576$

$\mathrm{H},-2.271158706,-0.7696575204,-0.6955158449$

$H, 0.2721245595,-3.3760581144,-1.2164216455$

$\mathrm{H},-1.1859579581,-3.5710096552,-2.2175670737$

$\mathrm{H}, 0.5097240224,2.89130579,0.2677005585$

$H, 0.958697897,2.7509514352,-1.3922730916$

State $=1-A \quad N \mid m a g=0$

\section{8}

Brutoformula: C3H12N9P1

0,1

N, $-0.5085851289,1.4735398241,-0.4354773447$ $P,-0.0016877928,0.0002551036,-1.1817847607$ $\mathrm{N}, 1.5306818949,-0.2962636742,-0.4406995347$ $\mathrm{N},-1.020857056,-1.176109508,-0.4313648115$ C, $-0.7231509507,-2.3782316139,-0.0870924165$ C, $2.4212859151,0.5604864398,-0.0869511359$ C, $-1.6974068139,1.8184752684,-0.0891646758$ $\mathrm{N},-2.8266156128,1.0282773061,-0.148317929$ $\mathrm{N},-1.934310441,3.106267522,0.3967986207$ $\mathrm{N}, 2.3004236375,1.9337053395,-0.1393742279$ $\mathrm{N}, 3.6536350742,0.1208904831,0.4015064734$ $\mathrm{N}, 0.5247088272,-2.9623426588,-0.1563960716$ $\mathrm{N},-1.7163106745,-3.2262860401,0.4076971836$ $\mathrm{H},-3.5604669068,1.2566264804,0.5066566199$ $\mathrm{H},-2.603281933,0.0350581575,-0.2198127542$ $\mathrm{H},-1.1756179784,3.7422246756,0.1995131972$ H, $-2.8380951489,3.4952459346,0.1628601979$ $\mathrm{H}, 3.8250196601,-0.8542077574,0.20474398887$ $\mathrm{H}, 4.4433134796,0.7091156328,0.1707697156$ $\mathrm{H}, 2.8600286273,2.4514454005,0.5228321892$ $H, 1.328451888,2.2357850337,-0.2145956726$ $H,-2.6479929245,-2.8857915438,0.2207560051$ $\mathrm{H},-1.6048449777,-4.2036778099,0.1729217022$ $\mathrm{H}, 0.6984956709,-3.7115396695,0.4979793605$ $H, 1.2731796633,-2.272948329,-0.234003931$

$H F=-955.9464139 \mathrm{NImag}=0$

\section{$48 \mathrm{H}+$}

Brutoformula: C3H13N9P1(1+)

1,1

$\mathrm{N},-1.2843167465,0.8985650484,0.2706422879$

P, $-0.0038191742,-0.0009193915,0.7519929669$

$\mathrm{H},-0.0211198668,0.0031187029,2.1613926261$

$\mathrm{N}, 1.4245360687,0.6613424519,0.3080868579$

$\mathrm{N},-0.1358729404,-1.5645864739,0.2878339518$

C, $-1.3275692651,2.1857253574,-0.0141826368$

C. $2.5552975336,0.0640969,-0.0146192942$

C,-1.2251885736,-2.2513036325,0.0008357517

$\mathrm{N},-0.249805684,2.9957002244,-0.0734444443$

$\mathrm{N},-2.5357979651,2.739104533,-0.2751550558$

$\mathrm{N},-2.4623043821,-1.7222800606,-0.0966962774$

$\mathrm{N},-1.0971406915,-3.5806377526,-0.2229876794$

$\mathrm{N}, 3.6424421227,0.8409652353,-0.2377198103$

$\mathrm{N}, 2.7081619222,-1.268984329,-0.1512428314$

$\mathrm{H},-3.3597231802,2.1950295716,-0.0820552943$

$\mathrm{H},-2.6491880808,3.729762749,-0.4136992423$

$\mathrm{H},-0.3259521208,3.9504616926,-0.3842369959$

$H, 0.6648846896,2.5582067531,-0.0199167255$

$\mathrm{H},-3.2509947375,-2.2751382026,-0.3901852027$

$\mathrm{H},-2.5406154029,-0.7103569193,-0.0674994398$

$H,-0.2199201348,-4.0188447876,0.0021129732$

$\mathrm{H},-1.8947401409,-4.1754209481,-0.3760967888$

$\mathrm{H}, 4.5547375733,0.4457211148,-0.3960837152$

$\mathrm{H}, 3.5910444031,1.8128908325,0.0173211895$

$\mathrm{H}, 1.8709451793,-1.8416999191,-0.1072799212$

$H, 3.5720195936,-1.6705187512,-0.4771172016$

$H F=-956.3750699 \mathrm{NImag}=0$

\section{$48 \mathrm{H}+$ protonated on $\mathrm{C}=\mathrm{N}$}

Brutoformula: C3H13N9P1(1+)

1,1

N,2.3378547412,-2.6488899355,0.091774228

P, $-0.0849465775,0.2511187855,-0.9333065043$ $\mathrm{N}, 0.4482250092,1.429392534,0.1883980455$ $\mathrm{N}, 0.8187535757,-1.1403536964,-0.725953511$ C,1.7125879796,-1.4436219659,0.1906224074 C, $0.6374353218,2.671017693,-0.1983027626$

$\mathrm{N},-1.5559383922,-0.2236647357,0.1023523244$ $\mathrm{N}, 0.3295004582,3.1892780095,-1.4221824896$ $\mathrm{N}, 1.1760773785,3.5501249523,0.6893718422$ $\mathrm{N}, 2.0323044309,-0.6688518211,1.2533162036$ $\mathrm{H},-1.8384821331,0.4440398614,0.8093213977$ C, $-2.3141025204,-1.2976514725,-0.0885907292$ $\mathrm{N},-3.5588166533,-1.3799713672,0.4260529963$ $\mathrm{N},-1.8371418693,-2.3177297803,-0.8114062242$ $\mathrm{H}, 1.2680566854,3.2379017501,1.6422452689$ H,1.1198120145,4.5444946583,0.5357787311 $\mathrm{H}, 0.7184139971,4.072849827,-1.711536361$ $\mathrm{H}, 0.0645644732,2.5535298557,-2.1596053041$ $\mathrm{H}, 2.8516822909,-0.8619499091,1.8071349617$ $H, 1.6259669361,0.2647075388,1.2725595013$ H,2.2473303918,-3.1412050919,-0.7817196636 $\mathrm{H}, 3.1167568571,-2.8889303856,0.6832405391$ H, $-4.0314691114,-2.2659986896,0.5069922025$ $\mathrm{H},-3.9983389578,-0.5769477065,0.8447972232$ 
$\mathrm{H},-0.8413554139,-2.3165168205,-1.0415515749$ $\mathrm{H},-2.4447309124,-3.036172091,-1.1698027514$

$H F=-956.3653118 \quad \mathrm{NImag}=0$

\section{9}

Brutoformula: C15H36N9P1

0,1

$\mathrm{N}, 1.4793129146,0.2446168997,0.6891684595$

$\mathrm{P},-0.0090969608,0.0108252081,-0.1658142045$

$\mathrm{N},-0.5503382432,-1.4011855122,0.6786739574$

$\mathrm{N},-0.9549016026,1.18125204,0.6882463796$

C, $-1.9233644819,1.8765596367,0.2103554297$

C, $-0.6577122817,-2.5848258067,0.1914046335$

C, $2.5692695835,0.7173325575,0.2010913377$

$\mathrm{N}, 2.7365508168,1.5266970821,-0.9271778154$ $\mathrm{N}, 3.7832126683,0.4191641427,0.8439022057$

$\mathrm{N},-0.0041982817,-3.1293110124,-0.918393865$

$\mathrm{N},-1.5257864251,-3.4975802426,0.8152426075$

$\mathrm{N},-2.7312031186,1.5947459083,-0.8956368715$

$\mathrm{N},-2.2659076475,3.084453251,0.8428368911$

C, $1.6998828103,2.4366183043,-1.3817335692$

C, $3.8299929338,1.328309478,-1.8653518254$

C, $3.73490688001,-0.5959492094,1.8896892219$

C,4.7020758954,1.5110717744,1.1617897969

C,-2.4174014453,-2.9582191413,1.8351877158 C, $-1.0270935566,-4.829892336,1.1522585892$

C, $1.3041803218,-2.6650302881,-1.3442182312$

C, $-0.684334871,-3.9954581024,-1.868506043$

C, $-1.3418368214,3.57176622,1.8600739715$

C,-3.6647384514,3.3282388921,1.1912053895

C, $-2.9889760314,0.2337311866,-1.3316208959$

C, $-3.1379373921,2.6249494452,-1.8385100008$

$H, 1.1495195807,2.0478845841,-2.2470672563$

$\mathrm{H}, 2.1606770518,3.3919096518,-1.6660308115$ $\mathrm{H}, 0.9898113574,2.6234132486,-0.5788052901$ $\mathrm{H}, 4.6376735162,2.2990316694,0.4154970949$ $H, 5.7307881038,1.1395612505,1.1901993099$ $\mathrm{H}, 4.4697453465,1.9491966966,2.1441778655$ H,3.285467955,-0.2137754879,2.8156440142 $\mathrm{H}, 4.7560332392,-0.9285877533,2.0975820444$ H,3.1363832284,-1.4423105942,1.5614529583 $\mathrm{H}, 3.4383209055,1.0238355382,-2.8456565307$ $\mathrm{H}, 4.4975010504,0.5498100059,-1.5022266107$ $H, 4.4099571401,2.2499784724,-2.0104038214$ $\mathrm{H},-1.4261281856,3.00799738966,2.7984746717$ $\mathrm{H},-1.5634351872,4.6253081336,2.0537909469$ $\mathrm{H},-0.3167777012,3.4735735289,1.5110438009$ H,-3.903084722,2.9121695086,2.1817219937 H, $-4.3299113757,2.871410031,0.462601892$ $\mathrm{H},-3.8617603482,4.4040975326,1.217778906$ $\mathrm{H},-3.2139435653,-3.6850863541,2.0188108692$ $\mathrm{H},-2.8511012856,-2.0211468332,1.494526699$ $H,-1.8918969043,-2.7548950699,2.7776018275$ $H,-1.8526847013,-5.547806556,1.1628069941$ $\mathrm{H},-0.5570565109,-4.8351012046,2.1473067029$ H, $-0.2881216995,-5.1609170007,0.4266659847$ $H, 1.7886812903,-2.1243480929,-0.5341969413$
H,1.2501174221,-2.0039728615,-2.2176840463 H, 1.9259836722,-3.5318589205,-1.6042135834 H, $-0.1584286032,-4.9521116566,-1.9917566749$ $\mathrm{H},-0.7321967716,-3.5127099008,-2.8541791178$ $\mathrm{H},-1.6991204157,-4.1961492268,-1.5317665592$ H,-4.2293037028,2.6518758551,-1.9610698561 $\mathrm{H},-2.6970508391,2.4307960832,-2.8259137635$ $\mathrm{H},-2.8012457278,3.6005206592,-1.4945652962$ $\mathrm{H},-2.3937807023,-0.0450608163,-2.2096424319$ H,-4.0517335922,0.1342722447,-1.5889500533 $\mathrm{H},-2.7624555312,-0.4636841283,-0.528103161$

$H F=-1427.6626142 \quad \mathrm{NImag}=0$

$49 \mathrm{H}+$

Brutoformula: C15H37N9P1(1+) 1,1

$\mathrm{N},-0.7971866321,1.1978904156,-0.2095950051$ $P, 0.2755214395,0.1852277762,0.4882033516$ $\mathrm{H}, 0.2268686289,0.3639248283,1.8945710791$ $\mathrm{N}, 1.7741643061,0.5743039812,-0.0034603068$ $\mathrm{N},-0.0672202106,-1.3647213861,0.1097359833$ C, $-1.367357054,2.3060491712,0.2003734982$ C, $2.8366167294,-0.1597938908,-0.2590275091$ C,-1.2055749843,-2.0172184946,0.0065572649 $\mathrm{N},-0.9154473431,3.1252940041,1.2096808512$ $\mathrm{N},-2.5285483928,2.695026529,-0.4167678202$ N,-2.2868983445,-1.8557621689,0.8363231658 $\mathrm{N},-1.3238227723,-2.9655385166,-0.9694019292$ $\mathrm{N}, 3.6666738733,0.2381752515,-1.2668364571$ N,3.2157245369,-1.2762687058,0.4412542528 C, $-3.2340235434,1.7473515813,-1.2743516465$ C,-2.8185445138,4.1014563623,-0.7113889893 C, $0.5055751912,3.3047113012,1.4981646985$ C, $-1.8172683399,3.848560715,2.1047635017$ C, $-3.670684544,-2.0078398005,0.3861184983$ C,-2.1279110081,-1.3290913954,2.1860799578 C,- $-0.3889432355,-2.9614517512,-2.0918483168$ C, $-2.022485949,-4.2362013894,-0.760702947$ C,5.11999085,0.0707409282,-1.2112089024 C,3.200665386,1.2179634903,-2.2454951694 C,2.7696992802,-1.4915354683,1.8118907338 C, $3.7991130895,-2.4503270439,-0.207228702$ $H,-3.1427897173,0.7430792325,-0.8700991136$ $\mathrm{H},-2.8288529214,1.7458248237,-2.2926080009$ H,-4.2879587149,2.0316037552,-1.3142161809 H,-2.0289521 267,4.7447930107,-0.3323345474 H,-3.7729857922,4.4130372148,-0.27745572675 $\mathrm{H},-2.8736098782,4.2372945934,-1.7960711602$ $\mathrm{H}, 0.7686628724,2.8977030998,2.4807918411$ $\mathrm{H}, 0.7375731816,4.3750736551,1.5045598528$ H,1.1172235961,2.8216521274,0.7397308559 $\mathrm{H},-1.538328802,3.6294833826,3.1405427991$ H, $-2.8449813565,3.527919885,1.9496267433$ $\mathrm{H},-1.7578313796,4.933168392,1.963271564$ $\mathrm{H}, 3.695149089,1.0221954075,-3.1997741908$ $H, 3.4386394667,2.2399671631,-1.929779555$ H,2.1242245871,1.1365912664,-2.3687070628 
$H, 5.5954263221,1.0524157661,-1.2984070389$ $H, 5.4857184434,-0.5593232315,-2.0274697421$ $\mathrm{H}, 5.416840166,-0.3682318286,-0.2618634697$ $H, 4.7925560266,-2.6810551334,0.1901839816$ $\mathrm{H}, 3.8738004566,-2.29267089,-1.2803861703$ H,3.1495058075,-3.3142527938,-0.0321635552 H,3.5695801706,-1.9895529513,2.3659796087 $\mathrm{H}, 1.8711754999,-2.1163291102,1.8557204331$ $H, 2.571513328,-0.5353710855,2.2940866276$ $\mathrm{H},-0.0969363039,-1.9417236331,-2.3272979502$ $\mathrm{H},-0.8846422781,-3.4051277161,-2.9581148833$ $H, 0.5123079467,-3.5425607871,-1.8663172127$ $\mathrm{H},-1.3177844447,-5.0593901847,-0.913231681$ $\mathrm{H},-2.8516419057,-4.3617866138,-1.4631046355$ $H,-2.4033248327,-4.30241884444,0.2555187398$ $\mathrm{H},-3.7037276586,-2.1523921729,-0.6911170452$ H,-4.2272460275,-1.0969990237,0.6283387017 $H,-4.1707828691,-2.8499881121,0.875009812$ $\mathrm{H},-2.3102486578,-0.24897064,2.2380729008$ H,-1.1264557674,-1.5420892094,2.5550986898 $\mathrm{H},-2.8456585183,-1.8254441518,2.843909531$

$H F=-1428.1154227 \quad N I m a g=0$

\section{0}

Brutoformula: H18N12P4

0,1

N,- $-1.0424055893,1.2576621121,-0.4696584989$ $\mathrm{P},-0.4694065153,-0.2166281734,-1.1663099555$ $\mathrm{N}, 1.1276845517,-0.29666851,-0.4195875377$ $\mathrm{N},-1.343807655,-1.400519852,-0.2968540833$ P,-2.0035298522,-1.1628041584,1.1157353077 $\mathrm{P},-0.2990266891,2.6380977808,-0.5119675647$ $\mathrm{P}, 2.0870323306,-1.4987950629,-0.732607672$ $\mathrm{N},-2.8726108845,-2.5385319926,1.5668503427$ $\mathrm{N},-3.1468578615,0.0728700697,1.2970382619$ $\mathrm{N},-0.922488249,-0.8538899063,2.3818063389$ N.1.4323527059,-2.9452103482,-0.1722947297 $\mathrm{N}, 3.6032050367,-1.5429828885,-0.0105905289$ $\mathrm{N}, 2.5688940503,-1.5397228582,-2.3553119659$ H,1.8453269433,-1.2341663824,-2.9959316866 $\mathrm{N},-1.072338506,3.8111457524,0.4236880499$ $\mathrm{N},-0.2017996457,3.3900344221,-2.0278397229$ $\mathrm{H}, 0.7361809888,3.607291422,-2.335348192$ $\mathrm{H},-0.7466614417,2.9376736681,-2.7504853054$ H, $-1.5596710325,4.5151559782,-0.1138814166$ H,-1.6411467377,3.4463044216,1.1766567486 $\mathrm{H}, 3.0543898289,-2.3620811368,-2.6915644902$ $N, 1.2986316032,2.6556723118,0.0273806959$ $H, 1.830991611,-3.8223266941,-0.4812232908$ $\mathrm{H}, 0.4124887576,-2.927358876,-0.1889697365$ $\mathrm{H}, 1.4447948514,3.1730538179,0.8837188419$ $\mathrm{H}, 1.6552275499,1.6960464987,0.0719664295$ H,3.588707767,-1.6554480196,0.9948012617
$\mathrm{H}, 4.2322762552,-0.8054786061,-0.3014397678$ $\mathrm{H},-2.9080636835,-3.2313920608,0.8300811779$ H, $-2.5817673578,-2.9439597729,2.4466174917$ $\mathrm{H},-1.1773392702,-0.0693966274,2.967958283$ $H, 0.0314214025,-0.7719068912,2.0445978721$ $\mathrm{H},-2.8728271803,0.8576185521,0.7040089849$ $\mathrm{H},-4.087858082,-0.2393579906,1.0889600555$

$H F=-2033.7612714 \quad \mathrm{NImag}=0$

$50 \mathrm{H}+$

Brutoformula: H19N12P4(1+) 1,1 $\mathrm{N},-0.7607813838,1.3517416655,-0.3031342178$ $\mathrm{H},-0.9417589572,-0.4578157711,-1.9149393753$ $\mathrm{N}, 1.2799518414,-0.2932802282,-0.9396102919$ $\mathrm{N},-0.839963125,-1.2393450247,0.4052195483$ P,-2.1965761309,-1.4001247097,1.2119497729 P, $-0.16716274,2.8021132687,-0.5322577199$ $P, 2.3826554852,-1.3983327247,-0.6647615308$ $\mathrm{N},-3.3223552174,-2.5704226847,0.8440404913$ N,-3.1067915026,-0.0232742351,1.059259552 $\mathrm{N},-1.7532620375,-1.9252547999,2.7289388338$ $\mathrm{N}, 1.9185969881,-2.3611912114,0.6039824484$ $\mathrm{N}, 3.9023782518,-0.9248879702,-0.1950057572$ $\mathrm{N}, 2.7603531288,-2.129376931,-2.1143491259$ $\mathrm{H}, 2.0207793778,-2.2360556416,-2.7931929404$ N. $-0.312536526,3.9414937905,0.6661969247$ $\mathrm{N},-1.0588844102,3.5503446364,-1.7254971182$ $\mathrm{H},-0.8402349529,4.4986652497,-1.9997386306$ $\mathrm{H},-1.4116113011,2.9757453329,-2.4771232779$ H, $-1.2335315196,4.3040355529,0.8704198387$ $H, 0.2775908765,3.8406688989,1.4803083641$ $\mathrm{H}, 3.4588763418,-2.8595763366,-2.1460474588$ $\mathrm{N}, 1.4793042346,2.7161262488,-0.7218521917$ $\mathrm{H}, 2.4395513312,-3.1982089606,0.8248346181$ $H, 0.9148318847,-2.4004248431,0.7736650965$ $H, 2.0036930481,3.5246895532,-1.0245020574$ $\mathrm{H}, 1.838472429,1.8120351336,-1.0200470691$ $\mathrm{H}, 4.0180467283,-0.5879100108,0.7506284125$ $\mathrm{H}, 4.4893670066,-0.4590370685,-0.8729458035$ $\mathrm{H},-3.893725109,-2.4223650383,0.0233844601$ $\mathrm{H},-3.0558190629,-3.536889766,0.9759819107$ H, $-2.4736294268,-2.1326072941,3.4072717282$ $\mathrm{H},-0.918524983,-1.5202274073,3.1282808677$ $\mathrm{H},-2.6071210855,0.8282812171,0.8173343661$ H, $-3.9760857829,0.089356334,1.5602388957$ $P,-0.3140936994,-0.1586882245,-0.6869315616$

$H F=-2034.2224429 \quad \mathrm{NImag}=0$ 